\title{
A Survey on 5G Usage Scenarios and Traffic Models
}

\author{
Jorge Navarro-Ortiz, Pablo Romero-Diaz, Sandra Sendra, \\ Pablo Ameigeiras, Juan J. Ramos-Munoz, Juan M. Lopez-Soler
}

\begin{abstract}
The fifth-generation mobile initiative, 5G, is a tremendous and collective effort to specify, standardize, design, manufacture, and deploy the next cellular network generation. 5G networks will support demanding services such as enhanced Mobile Broadband, Ultra-Reliable and Low Latency Communications and massive Machine-Type Communications, which will require data rates of tens of Gbps, latencies of few milliseconds and connection densities of millions of devices per square kilometer. This survey presents the most significant use cases expected for $5 \mathrm{G}$ including their corresponding scenarios and traffic models. First, the paper analyzes the characteristics and requirements for 5G communications, considering aspects such as traffic volume, network deployments, and main performance targets. Secondly, emphasizing the definition of performance evaluation criteria for 5G technologies, the paper reviews related proposals from principal standards development organizations and industry alliances. Finally, well-defined and significant 5G use cases are provided. As a result, these guidelines will help and ease the performance evaluation of current and future 5G innovations, as well as the dimensioning of $5 \mathrm{G}$ future deployments.
\end{abstract}

Index Terms-5G, IMT-2020, usage scenarios, traffic models.

\section{INTRODUCTION}

$\mathbf{F}$ ITH-GENERATION $(5 \mathrm{G})$ is a tremendous and collective effort to specify, standardize, design, manufacture, and deploy the next cellular network generation. $5 \mathrm{G}$ is an ambitious and challenging project that involves all the stakeholders and players including standards and normative organizations, telco (real and virtual) operators, manufacturers, content and service providers, academia, and final users.

While $4 \mathrm{G}$ was conceived to provide mobile broadband communications, $5 \mathrm{G}$ is being designed with the ambitious goal of becoming a key asset in the introduction of the digital technologies in multiple economic and societal sectors. 5G infrastructures are expected to play a key role on the evolution of sectors such as the industry 4.0, automotive and mobility, transportation, healthcare system, energy industry, media and entertainment ecosystem, and additionally bring new value chains for new business models. As a consequence, a wide range of evolving and unprecedented use cases and business models will come along the $5 \mathrm{G}$ ecosystem. Therefore, it is

This work is partially funded by the Spanish Ministry of Economy and Competitiveness (project TEC2016-76795-C6-4-R), the H2020 research and innovation project 5G-CLARITY (Grant No. 871428) and the Andalusian Knowledge Agency (project A-TIC-241-UGR18).

J. Navarro-Ortiz (corresponding author), S. Sendra, P. Romero-Diaz, Pablo Ameigeiras, Juan J. Ramos-Munoz, and J.M. Lopez-Soler are with the Department of Signal Theory, Telematics and Communications, University of Granada, Spain (e-mails: \{jorgenavarro, ssendra, pabloromerodiaz, pameigeiras, jjramos, juanma\}@ugr.es) fundamental for the success of $5 \mathrm{G}$ to accurately establish the use cases for the vertical sectors, as well as the performance requirements they impose.

With these challenging goals, an immense number of initiatives developed by organizations such as ITU (International Telecommunication Union), 3GPP (Third Generation Partnership Project), 5G PPP (5G Infrastructure Public Private Partnership), and NGMN (Next Generation Mobile Networks Alliance) have been launched, along with notable investments.

In this respect, the evaluation and validation methodologies play a key role in the assessment of the potential of any $5 \mathrm{G}$ research innovation. The various aspects of the scenario, the different models characterizing the system, the performance targets, as well as the QoS demands completely determine the evaluation outcome.

Accordingly, any present and future 5G deployment should be properly dimensioned. For that, it is necessary to establish and select right usage scenarios which cover the envisaged main environments and services. Complementary, for all the selected use cases, the definition of a traffic load model will allow the research community, manufacturers and developers to estimate future demands. All these issues are of radical importance and will influence the success of 5G.

To achieve these goals, the objective of this survey is to identify and provide an overview of the most significant $5 \mathrm{G}$ use cases and, for all of them, to propose the adoption of precise traffic generation models.

As a result, the main contribution of this paper is to serve as a reference work so that $5 \mathrm{G}$ researchers and other stakeholders will have a framework of reference with several well-defined use cases with their corresponding selected traffic models. It will allow evaluating the performance of new $5 \mathrm{G}$ innovations and dimensioning future deployments. For that purpose, this survey compiles the main references from the major Standards Development Organizations (SDOs) and industry associations. Besides, the most relevant use cases with the corresponding traffic models are suggested.

The rest of the paper is organized as follows. Section II describes the ITU IMT-2020 (International Mobile Telecommunications-2020) usage scenarios and requirements, as well as middle-term traffic forecasts for the period from 2020 to 2030. Section III analyzes the main test cases and their corresponding traffic models from the main SDOs and stakeholders, including regional initiatives and industry alliances. In Section IV we discuss the adoption of a set of relevant use cases, and associated traffic models, for dimensioning and performance evaluation of 5G systems. Finally, 
the conclusions and future research directions are included in Section VI.

\section{5G USAGE SCENARIOS, REQUIREMENTS AND TRAFFIC ESTIMATES}

Fourth-Generation (4G) and $5 \mathrm{G}$ are terms used to identify the 4th and 5th generation of mobile technology. While these terms remain undefined [1], it is generally accepted that $4 \mathrm{G}$ refers to the mobile technologies fulfilling the IMT-Advanced requirements [2] and $5 \mathrm{G}$ refers to mobile systems fulfilling the ITU IMT-2020 requirements.

Since IMT-2020 technologies are not yet completely specified, this section summarizes values and trends from current International Communications Union - Radio-communication Sector (ITU-R) recommendations related to $5 \mathrm{G}$ requirements, usage scenarios and traffic estimates for 2020 and beyond.

\section{A. Usage scenarios}

Report ITU M.2083-0 [3] defines the framework and overall objectives of the future development of "IMT for 2020 and beyond" to better serve the needs of the networked society in the future. IMT-2020 is envisaged to expand and support diverse usage scenarios and applications that will continue beyond the current IMT. These usage scenarios include:

- Enhanced Mobile Broadband (eMBB), which addresses the human-centric use cases for access to multimedia content, services and data (e.g. 3D video, UHD (UltraHigh Definition) screens, augmented reality, etc.).

- Ultra-Reliable and Low Latency Communications (URLLC), which has stringent requirements for capabilities such as throughput, latency and availability (e.g. industry automation, mission-critical applications, self-driving cars, etc.).

- Massive Machine-Type Communications (mMTC), for scenarios with a very large number of connected devices typically transmitting a relatively low volume of nondelay sensitive data (e.g. smart grid, smart home/building, smart cities, etc.).

Since unforeseen use cases are expected to emerge in short future, $5 \mathrm{G}$ systems have to provide flexibility to support these new requirements. Fig. 1 shows some examples of envisioned usage scenarios for "IMT for 2020 and beyond", whereas Fig. 2 shows the importance of each key capability for the aforementioned usage scenarios (i.e. eMBB requires high data rate, whereas mMTC needs high connection density for massive deployment and, URLLC demands ultra-low latency).

Finally, report ITU-R M.2412 [4] defines the guidelines for evaluation of the candidate IMT-2020 radio interface technologies (RITs) or sets of RITs (SRITs) for IMT-2020 for many test environments. These test environments are defined as a combination of geographic environment and usage scenario. The report defines the following five test environments, including the network layout, the evaluation configurations (in terms of equipment parameters, device deployment, mobility and traffic models), antenna characteristics, and channel models:

- Indoor hotspot-eMBB

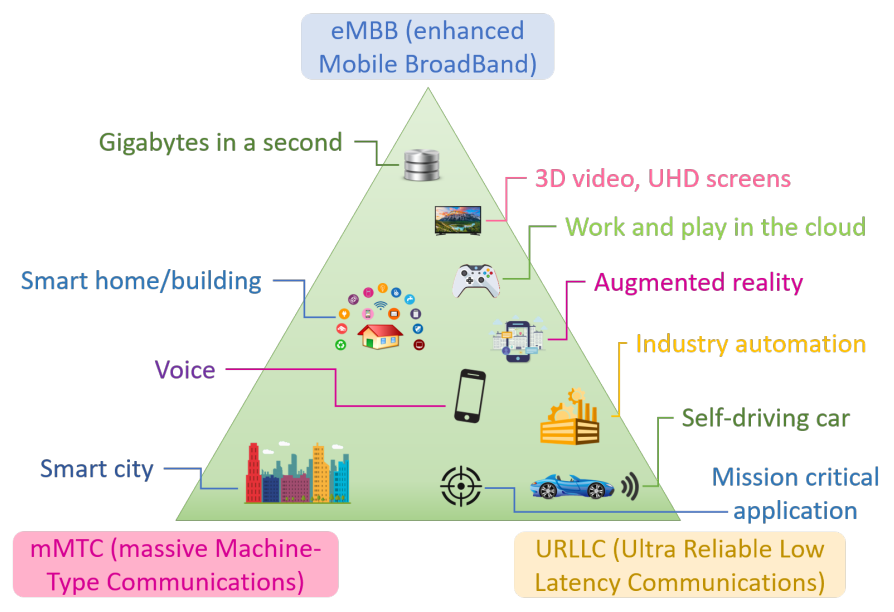

Figure 1: Usage scenarios of IMT for 2020 and beyond [3].

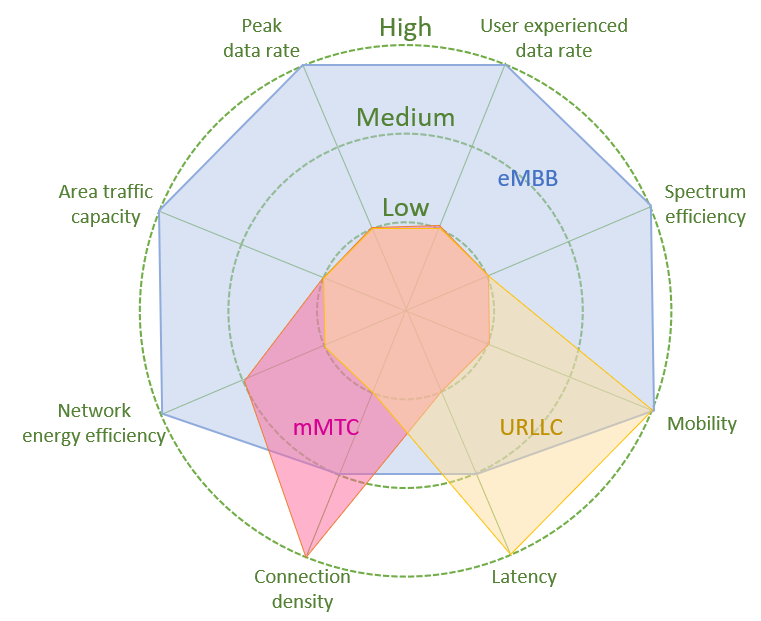

Figure 2: The importance of key capabilities in different usage scenarios [3].

- Dense urban-eMBB

- Rural-eMBB ${ }^{1}$

- Urban macro-mMTC

- Urban macro-URLLC

ITU-R M.2412 report makes a comprehensive definition of these test environments (see Table I). In the case of eMBB, which is the logical evolution of conventional data services in 4G, three typical environments are considered (urban and rural for outdoors, and indoor hotspot), but only the urban scenario is contemplated for the new MMTC and URLLC services.

Regarding traffic models, this report only considers the full buffer model ${ }^{2,3}$. However, the usage of the well-known full buffer traffic model may provide non-realistic performance evaluations (e.g. for scheduling in Long Term Evolution (LTE) networks [6]). In this sense, Chiaraviglio [7] also claims

\footnotetext{
${ }^{1}$ Although rural scenarios are considered, the relevant technologies employed in 5G are "urban" in nature [5].

${ }^{2}$ In the full buffer traffic model, there is an infinite amount of data bits awaiting transmission in the output buffer associated with each data source.

${ }^{3}$ For urban macro-mMTC, a simple non-full buffer traffic model is also considered assuming 1 message/period/device with packet arrivals following a Poisson process.
} 
for new traffic models for $5 \mathrm{G}$, considering the new QoS requirements. He suggests to evaluate $4 \mathrm{G}$ using services such as eMBB or URLLC and proposes to employ scaling factors for these services in $5 \mathrm{G}$.

Similarly, the adopted scenario will also be decisive, since it will have an enormous impact on some performance metrics such as user throughput and energy efficiency [8]. Moreover, the combination of scenario and traffic load may be fundamental for the performance evaluation of many features and mechanisms [9].

Table I: Summary of IMT-2020 test environments

\begin{tabular}{|c|c|c|c|}
\hline Name & Description & Scenario & $\begin{array}{l}\text { Traffic } \\
\text { patterns }\end{array}$ \\
\hline $\begin{array}{l}\text { Indoor } \\
\text { hotspot- } \\
\text { eMBB }\end{array}$ & $\begin{array}{l}\text { Offices } \\
\text { and/or } \\
\text { shopping } \\
\text { malls }\end{array}$ & $\begin{array}{l}\text { Environment: floor with an area } \\
\text { of } 120 \mathrm{~m} \times 50 \mathrm{~m} \\
\text { Users: stationary or pedestrian } \\
\text { Deployment: } 12 \text { sites which are } \\
\text { placed in } 20 \text { meter spacing }\end{array}$ & Full buffer \\
\hline $\begin{array}{l}\text { Dense } \\
\text { urban- } \\
\text { eMBB }\end{array}$ & $\begin{array}{l}\text { City with } \\
\text { high user } \\
\text { density }\end{array}$ & $\begin{array}{l}\text { Environment: urban environment } \\
\text { with } 19 \text { sites (Inter Site Distance } \\
\text { (ISD) = 200m) } \\
\text { Users: pedestrian and vehicular } \\
\text { Deployment: Composed of two } \\
\text { layers, macro and micro. The } \\
\text { macro layer follows a regular } \\
\text { grid with three Transmission Re- } \\
\text { ception Points (TRxPs) per site, } \\
\text { and the micro layer is com- } \\
\text { posed of } 3 \text { micro sites randomly } \\
\text { dropped in each macro TRxP } \\
\text { area }\end{array}$ & Full buffer \\
\hline $\begin{array}{l}\text { Rural- } \\
\text { eMBB }\end{array}$ & $\begin{array}{l}\text { Rural } \\
\text { area with } \\
\text { larger and } \\
\text { continuous } \\
\text { coverage }\end{array}$ & $\begin{array}{l}\text { Scenario: rural environment with } \\
19 \text { sites (ISD }=1732 \mathrm{~m} \text { or } 6000 \\
\mathrm{~m}) \\
\text { Users: pedestrian, vehicular and } \\
\text { high speed vehicular } \\
\text { Deployment: regular grid as in } \\
\text { the dense urban-eMBB environ- } \\
\text { ment }\end{array}$ & Full buffer \\
\hline $\begin{array}{l}\text { Urban } \\
\text { macro- } \\
\text { mMTC }\end{array}$ & $\begin{array}{l}\text { City with a } \\
\text { high num- } \\
\text { ber of con- } \\
\text { nected ma- } \\
\text { chine type } \\
\text { devices }\end{array}$ & $\begin{array}{l}\text { Scenario: urban environment } \\
\text { with } 19 \text { sites (ISD }=500 \mathrm{~m} \text { ) } \\
\text { Deployment: regular grid as } \\
\text { in the dense urban-eMBB } \\
\text { environment }\end{array}$ & $\begin{array}{l}\text { Poisson } \\
\text { packet } \\
\text { arrival (1 } \\
\text { message } \\
\text { per day } \\
\text { or every } 2 \\
\text { hours) }\end{array}$ \\
\hline $\begin{array}{l}\text { Urban } \\
\text { macro- } \\
\text { URLLC }\end{array}$ & $\begin{array}{l}\text { City with } \\
\text { services } \\
\text { requiring } \\
\text { URLLC } \\
\text { communi- } \\
\text { cations }\end{array}$ & $\begin{array}{l}\text { Scenario: regular grid as in the } \\
\text { dense urban-eMBB environment } \\
\text { Deployment: regular grid as in } \\
\text { the dense urban-eMBB environ- } \\
\text { ment }\end{array}$ & Full buffer \\
\hline
\end{tabular}

\section{B. $5 G$ requirements}

Although many organizations (e.g. [10], [11], [12], [13]) and works (e.g. [14], [15], [16], [17], [18], [19], [20]) have devised the $5 \mathrm{G}$ requirements, it has not been until recently that ITU has formally specified them. The IMT-2020 technical requirements are included in Recommendation ITU-R M.2410 [21], summarized in Fig. 3. Some of the main targets are $20 \mathrm{Gbps}$ for eMBB, a latency of $4 \mathrm{~ms}$ for eMBB and $1 \mathrm{~ms}$ for URLLC and a connection density of $10^{6}$ devices $/ \mathrm{km}^{2}$ for mMTC. Table II provides the required values for these Key Performance Indicators (KPIs).

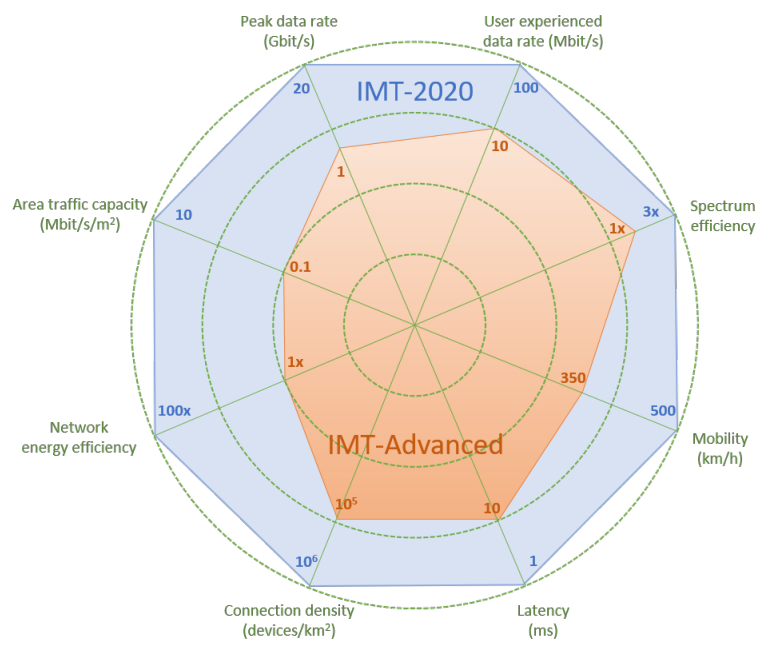

Figure 3: Enhancement of key capabilities from IMT-Advanced to IMT-2020 [3].

\section{Traffic estimates from 2020 to 2030}

In addition to current traffic mixes and traffic generation models, it is also critical to understand the evolution of the traffic load in the next years for the performance evaluation of these technologies. For that purpose, report ITU-R M.23700 [22] analyses trends impacting future IMT traffic growth beyond the year 2020. This work also estimates the traffic demands for the period from 2020 to 2030 .

According to this report, the main drivers influencing the growth of future IMT traffic are:

- Video usage: video-on-demand services with highresolution content (HD/UHD) will account for two-thirds of all mobile traffic.

- Device proliferation: more than 1.4 billion smartphones and tablets are forecasted.

- Application uptake: more than 270 billion apps are expected to be downloaded.

ITU-R M.2370-0 report includes different estimations for traffic forecast from 2020 to 2030 using different sources. This evolution will differ between countries due to social and economic differences, but it is expected that global IMT traffic will grow in the range of 10-100 times over this period. For example, Fig. 4 depicts the evolution of global mobile subscriptions for different devices. It is estimated that the global number of subscribers increases, between 2020 and 2030, from 6.3 to 12 billion for smartphones, from 1.3 to 5 billion for tablets and disappears for non-smartphones. Besides,

Fig. 5 estimates Machine-to-Machine (M2M) subscriptions (with an increase from 7 to 97 billion devices between 2020 and 2030) and Fig. 6 shows the evolution of mobile traffic, differentiating between video, non-video and M2M traffic. As shown, mobile internet and M2M traffic will grow dramatically after 2020, being video traffic 6 times higher than that of non-video in 2030. Additionally, M2M traffic will increase from $7 \%$ to $12 \%$ in that period. Finally, Fig. 7 shows the forecasted increase of mobile traffic compared to the actual 
Table II: Technical performance requirements for IMT-2020 [21]

\begin{tabular}{|c|c|}
\hline $\begin{array}{l}\text { Performance } \\
\text { indicator }\end{array}$ & Value \\
\hline $\begin{array}{l}\text { Peak data } \\
\text { rate }\end{array}$ & $e M B B$ : DL 20 Gbps, UL $10 \mathrm{Gbps}$ \\
\hline $\begin{array}{l}\text { Peak spectral } \\
\text { efficiency }\end{array}$ & $\begin{array}{l}e M B B: \text { DL } 30 \mathrm{bps} / \mathrm{Hz} \text { (assuming } 8 \text { spatial streams), UL } \\
15 \mathrm{bps} / \mathrm{Hz} \text { (assuming } 4 \text { spatial streams) }\end{array}$ \\
\hline $\begin{array}{l}\text { User } \\
\text { experienced } \\
\text { data rate }\end{array}$ & Dense urban eMBB: DL $100 \mathrm{Mbps,} \mathrm{UL} 50 \mathrm{Mbps}$ \\
\hline \multirow{3}{*}{$\begin{array}{l}5^{\text {th }} \text { percentile } \\
\text { user spectral } \\
\text { efficiency }\end{array}$} & $\begin{array}{l}\text { Indoor hotspot eMBB: } \mathrm{DL} \quad 0.3 \mathrm{bps} / \mathrm{Hz} / \mathrm{TRxP}, \quad \mathrm{UL} \\
0.21 \mathrm{bps} / \mathrm{Hz} / \mathrm{TRxP}\end{array}$ \\
\hline & $\begin{array}{l}\text { Dense urban eMBB: DL } 0.225 \mathrm{bps} / \mathrm{Hz} / \mathrm{TRxP}, \quad \mathrm{UL} \\
0.15 \mathrm{bps} / \mathrm{Hz} / \mathrm{TRxP}\end{array}$ \\
\hline & $\begin{array}{lc}\text { Rural } \quad \text { eMBB: } \\
0.045 \mathrm{bps} / \mathrm{Hz} / \mathrm{TRxP}\end{array} \quad$ DL $\quad 0.12 \mathrm{bps} / \mathrm{Hz} / \mathrm{TRxP}, \quad$ UL \\
\hline \multirow{3}{*}{$\begin{array}{l}\text { Average } \\
\text { spectral } \\
\text { efficiency }\end{array}$} & $\begin{array}{l}\begin{array}{l}\text { Indoor hotspot } \\
6.75 \mathrm{bps} / \mathrm{Hz} / \mathrm{TRx} \mathrm{P}\end{array}\end{array}$ \\
\hline & $\begin{array}{l}\text { Dense urban eMBB: } \mathrm{DL} \quad 7.8 \mathrm{bps} / \mathrm{Hz} / \mathrm{TRxP}, \quad \mathrm{UL} \\
5.4 \mathrm{bps} / \mathrm{Hz} / \mathrm{TRxP}\end{array}$ \\
\hline & Rural eMBB: DL $3.3 \mathrm{bps} / \mathrm{Hz} / \mathrm{TRxP}$, UL 1.6bps/Hz/TRxP \\
\hline $\begin{array}{l}\text { Area traffic } \\
\text { capacity }\end{array}$ & $\begin{array}{l}\text { Depends on average spectral efficiency and site density; } \\
\text { target value for indoor hotspot eMBB is } 10 \mathrm{Mbps} / \mathrm{m}^{2}\end{array}$ \\
\hline $\begin{array}{l}\text { User plane } \\
\text { latency }\end{array}$ & $4 \mathrm{~ms}$ for eMBB, $1 \mathrm{~ms}$ for URLLC \\
\hline $\begin{array}{l}\text { Control } \\
\text { plane latency }\end{array}$ & $20 \mathrm{~ms}$ (recommended $10 \mathrm{~ms}$ ) \\
\hline $\begin{array}{l}\text { Connection } \\
\text { density }\end{array}$ & $10^{6} / \mathrm{km}^{2}$ for $\mathrm{m}$ \\
\hline $\begin{array}{l}\text { Energy effi- } \\
\text { ciency }\end{array}$ & $\begin{array}{l}\text { Support for a) efficient transmission of data in loaded or } \\
\text { power limited case and b) low energy consumption when } \\
\text { there is no data. }\end{array}$ \\
\hline Reliability & $\begin{array}{l}\left(1-10^{-5}\right) \text { success probability of transmitting a L2 PDU } \\
\text { of } 32 \text { bytes within } 1 \mathrm{~ms} \text { for urban macro URLLC }\end{array}$ \\
\hline \multirow[t]{3}{*}{ Mobility } & $\begin{array}{l}4 \text { classes defined: stationary }(0 \mathrm{~km} / \mathrm{h}) \text {, pedestrian }(0 \text { to } \\
10 \mathrm{~km} / \mathrm{h}) \text {, vehicular }(10 \text { to } 120 \mathrm{~km} / \mathrm{h}) \text { and high speed } \\
\text { vehicular }(120 \text { to } 500 \mathrm{~km} / \mathrm{h}) \text {. Supported mobility and } \\
\text { normalized data rate: }\end{array}$ \\
\hline & $\begin{array}{l}\text { Indoor hotspot eMBB: stationary, pedestrian; } 1.5 \mathrm{bps} / \mathrm{Hz} \\
\text { Dense urban eMBB: stationary, pedestrian, vehicular (up } \\
\text { to } 30 \mathrm{~km} / \mathrm{h} \text { ); } 1.12 \mathrm{bps} / \mathrm{Hz}\end{array}$ \\
\hline & $\begin{array}{l}\text { Rural } e M B B \text { : pedestrian, vehicular, high speed vehicular; } \\
0.8 \mathrm{bps} / \mathrm{Hz} \text { up to } 120 \mathrm{~km} / \mathrm{h}, 0.45 \mathrm{bps} / \mathrm{Hz} \text { up to } 500 \mathrm{~km} / \mathrm{h}\end{array}$ \\
\hline $\begin{array}{l}\text { Mobility } \\
\text { interruption } \\
\text { time }\end{array}$ & $0 \mathrm{~ms}$ for $\mathrm{eMBB}$ \\
\hline Bandwidth & $\begin{array}{l}\text { At least } 100 \mathrm{MHz} \text {; up to } 1 \mathrm{GHz} \text { for frequency bands } \\
\text { above } 6 \mathrm{GHz}\end{array}$ \\
\hline
\end{tabular}

global mobile traffic (2010-2013). As depicted, this estimation implies a global growth between 2300 -times and 14 000-times from 2010 to 2030, assuming 'lower' and 'upper' forecasting scenarios.

ITU-R M.2370-0 report also includes a description of traffic asymmetry for some of the most popular applications (e.g. video, audio, web browsing, social networking, file sharing, etc.), showing that downlink represents around $80-90 \%$ of the data traffic while UL contributes around 10-20\%.

It shall be noticed that [22] also includes the daily traffic profiles for the five major mobile applications (streaming, computing, gaming, communicating, and storage) for some of the regions (North America, Western Europe, and Central \& Eastern Europe).

These traffic forecasts will allow researchers to estimate the increase in traffic load for the performance evaluation of $5 \mathrm{G}$ and future mobile technologies under e.g the usage scenarios and test cases analyzed in this paper.

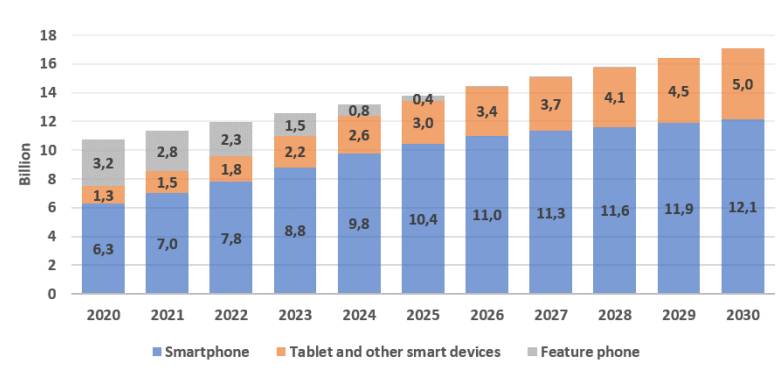

Figure 4: Estimation of global mobile subscriptions with different categories (provided by China) [22].

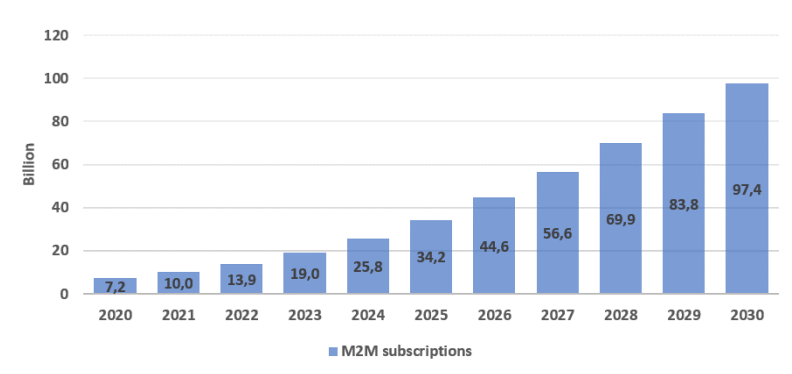

Figure 5: Estimation of global M2M subscriptions (provided by China) [22].

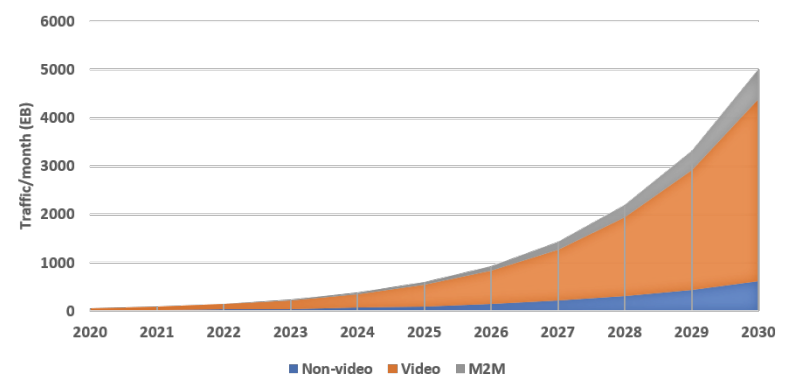

Figure 6: Estimation of mobile traffic by different service types globally (provided by China) [22].

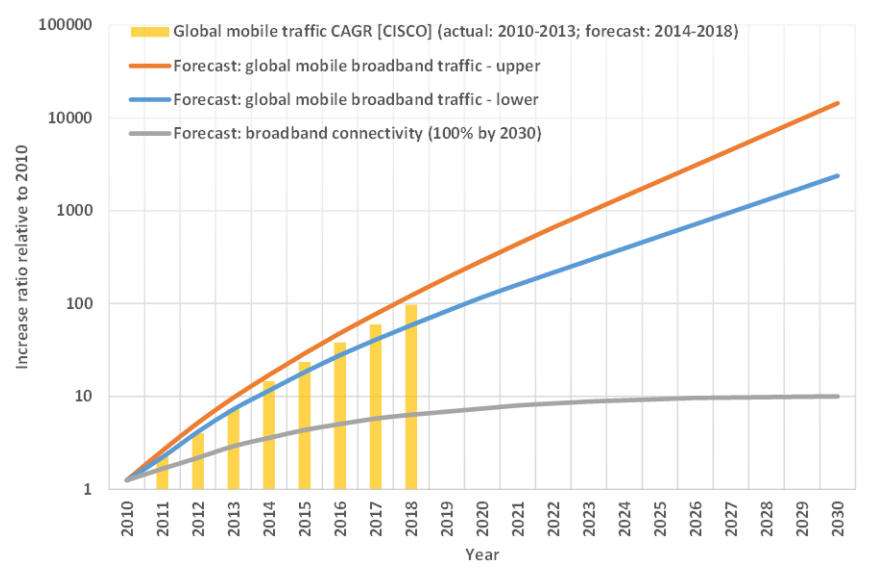

Figure 7: Forecast for global mobile broadband traffic growth for the period 2010 - 2030 (provided by Nokia) [22]. 


\section{5G STANDARDS DEVELOPMENT ORGANIZATIONS AND MAIN STAKEHOLDERS}

This section provides a landscape of the 5G-related activities in standards bodies, industry fora, and regional research efforts. Since the number of initiatives is huge, we have focused on those which define performance evaluation guidelines, including use cases and traffic models, specifically for $5 \mathrm{G}$. Besides, we have also included the performance evaluation guidelines for $4 \mathrm{G}$ from some of the major players. Following these criteria, we have summarized the test cases for the following organizations / initiatives: ITU, 3GPP, IEEE (Institute of Electrical and Electronics Engineering), WiMAX (Worldwide Interoperability for Microwave Access) Forum, TIA (Telecommunications Industry Association), research projects from $5 \mathrm{G}$ PPP (METIS, FANTASTIC-5G, mmMAGIC, SPEED-5G, and 5G-NORMA), and NGMN. We believe they are representative of the different Standards Development Organizations and industry associations.

To the best of our knowledge, most of the works in the literature rely on the use cases and the traffic patterns proposed in these initiatives. For example, the work presented in [23] presents a system-level simulator for $5 \mathrm{G}$ mobile networks and utilizes the use cases from 3GPP, assuming a full buffer traffic model. Similarly, [24] proposes another system-level simulator for the performance evaluation of $5 \mathrm{G}$ related technologies, identifying five emerging scenarios (some of them from IMTAdvanced and 3GPP): heterogeneous network, high-rise building, Device-to-Device (D2D) communication, high-speed mobile environment, and traditional typical simulation scenario. Nevertheless, only a brief description of these scenarios is given. Furthermore, [25] presents a solution for ultra-dense heterogeneous networks for $5 \mathrm{G}$ including a scenario with femtocells, picocells, mMTC and D2D communications. Another example can be found in [26], which tries to summarize the $5 \mathrm{G}$ requirements and related test environments, proposing classical scenarios from 3GPP and IMT-2020 (indoor isolated environment, urban macro coverage environment, dense urban area environment, and high speed train environment).

In addition, there are other research projects on $5 \mathrm{G}$, but most of them also rely on the information from the aforementioned works or consider use cases for specific technologies or infrastructures. For example, the 5GCHAMPION Europe-Korea collaborative project [27] provided the first fully-integrated and operational 5G prototype for the 2018 Winter Olympic Games, so the use cases were specific to the European and Korean infrastructure available for the project [28] [29].

In order to guide the reader, Fig. 8 summarizes the main traffic models proposed by these organizations, which will be explained in detail in the following subsections. Similarly, Fig. 9 depicts the main usage scenarios from these stakeholders.

\section{A. ITU}

ITU is the United Nations specialized agency for information and communication technologies (ICTs). Founded on the principle of international cooperation between governments (Member States) and the private sector (Sector Members, Associates and Academia), ITU is the premier global forum through which parties work towards consensus on a wide range of issues affecting the future direction of the ICT industry [30]. Within ITU, the ITU Radio-communication Sector (ITU$\mathrm{R})$ plays a vital role in the global management of the radiofrequency spectrum and satellite orbits [31].

The guidelines for the evaluation of radio interface technologies for IMT-2020 are included in Section II-A. For the sake of completeness, we also summarize here the guidelines for evaluation for IMT-Advanced (i.e. for 4G), which are included in Report ITU-R M.2135-1 [32]. Focusing on the usage scenarios, it defines four test environments:

- Indoor: targeting isolated cells at offices and/or hotspot based on stationary and pedestrian users.

- Microcellular: an urban environment with higher user density focusing on pedestrian and slow vehicular users.

- Base coverage urban: an urban macro-cellular environment targeting continuous coverage for pedestrian up to fast vehicular users.

- High speed: a rural macro-cellular environment with high speed vehicular and trains.

The network layout and the configurations for these scenarios are defined in the report. Although this report is intended for $4 \mathrm{G}$ communications, these scenarios are also relevant in today's networks and continue to be used in current relevant works (e.g. [33]).

Regarding traffic models, the report specifies the support of a wide range of services which can be classified under the following classes: conversational, interactive, streaming, and background. However, only two traffic models are defined:

- Full buffer traffic model: data sources with an infinite amount of data awaiting transmission.

- VoIP (Voice over IP): $12.2 \mathrm{kbps}$ codec with a $50 \%$ activity factor (with the same parameters as 3GPP, see Table V in the 3GPP subsection).

As already commented, the full buffer traffic model has widely been adopted both in simulationbased [34][35][36][37] and theoretical [38][39][40][41] investigations due to its simplicity.

Voice using codecs with $12.2 \mathrm{kbps}$ (e.g. using AMR-NB) has also been highly used for research since GSM and up to current 4G and 5G networks, e.g. [42][43][44][45][46].

Similarly to IMT-2020 [4], there are no service-specific traffic models defined for IMT-Advanced.

\section{B. $3 G P P$}

The original scope (1998) of 3rd Generation Partnership Project (3GPP) [47] was to produce Technical Specifications and Technical Reports for a $3 \mathrm{G}$ mobile system based on evolved GSM core networks and their corresponding radio access technologies, i.e. Universal Terrestrial Radio Access (UTRA).

Now, the 3GPP unites seven telecommunications standard development organizations (known as "Organizational Partners") including ARIB (the Association of Radio Industries and Businesses, Japan), ATIS (the Alliance for Telecommunications Industry Solutions, USA), CCSA (China Communications Standards Association), ETSI (the European Telecommunications Standards Institute), TSDSI (Telecommunications 


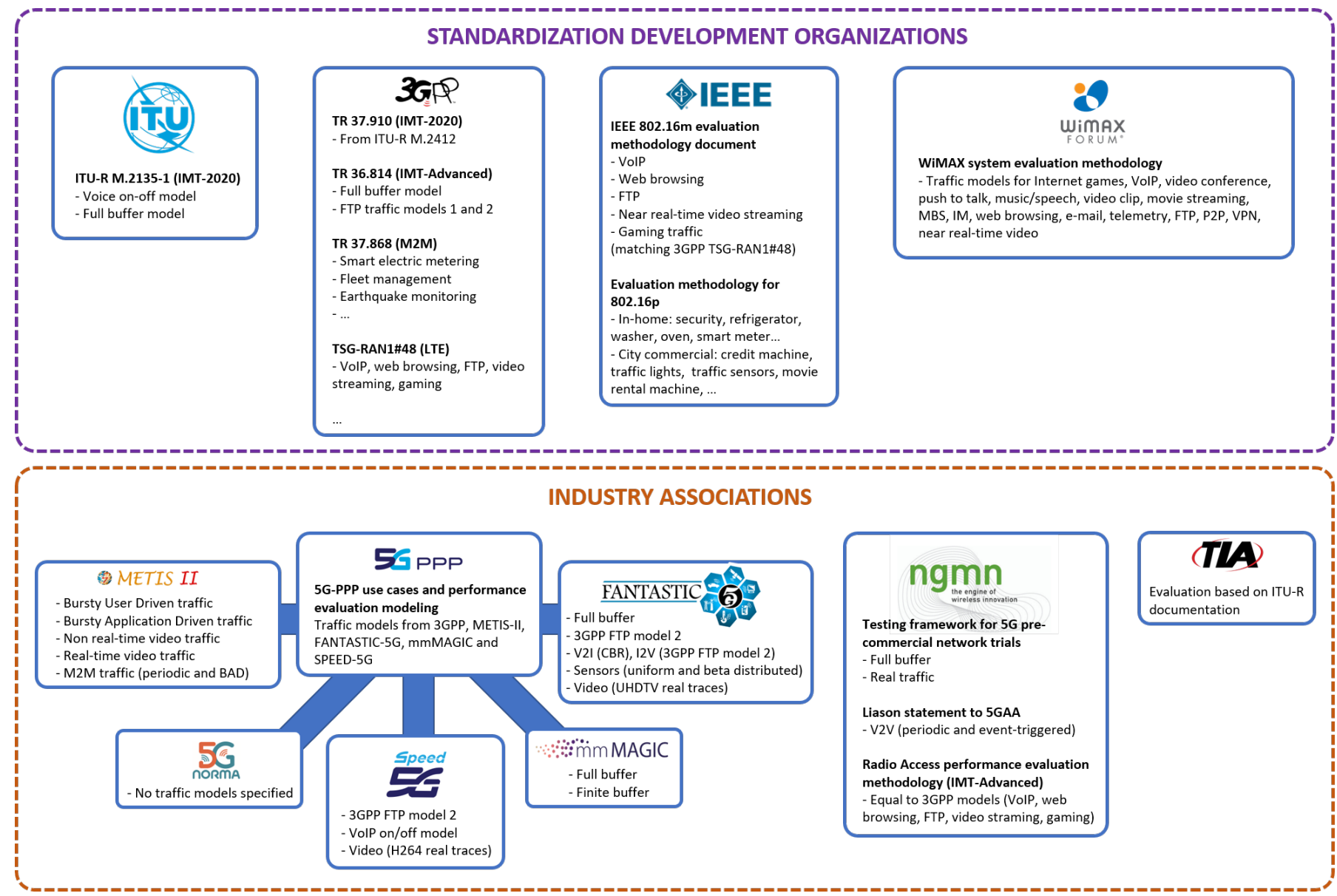

Figure 8: Summary of traffic models proposed by main SDOs and industry associations.

Standards Development Society, India), TTA (Telecommunications Technology Association, Korea), and TTC (Telecommunication Technology Committee, Japan), market associations and several hundred companies, providing a stable environment to produce the Reports and Specifications that define 3GPP technologies. These technologies includes radio access, the core transport network, and service capabilities.

The latest versions of the standard includes Long Term Evolution (LTE) (Release 8), LTE-Advanced (Release 10), and their evolutions (up to Release 14). The works for the first set of $5 \mathrm{G}$ standards started in Release 15 during the second half of 2017 were successfully completed in September 2018 [48]. 5G Phase 2 (Release 16) should be completed in December 2019 [49]. 3GPP has decided to submit the final specifications at the ITU-R WP5D meeting in February 2020 [50], based on these specifications, before the ITU-R deadline for the detailed specification submission in October 2020.

Within release 14, report 3GPP TR 38.913 [51] defines typical deployment scenarios and requirements for next-generation access technologies considering, but not limited to, the IMT2020 requirements. The considered usage scenarios are eMBB, mMTC, and URLLC. The deployment scenarios in this report are summarized in Table III. It shall be noted that most of the scenarios from IMT-2020 are included (indoor hotspot-eMBB, dense urban, rural and urban coverage for massive Machine-
Type Communications (MTC)). In addition, some new use cases are also proposed with different requirements, such as speed (high speed trains, highways, urban connected cars, commercial/light aircraft scenarios) or large coverage (extreme long distance, satellite extension to terrestrial).

Interestingly, the KPI targets are in line with those defined by IMT-2020 (see Table II). The target peak data rate is 20 Gbps for DL and $10 \mathrm{Gbps}$ for UL. The target peak spectral efficiency is $30 \mathrm{bps} / \mathrm{Hz}$ for DL and $15 \mathrm{bps} / \mathrm{Hz}$ for UL. The target control plane latency is $10 \mathrm{~ms}$. The target user plane latency, for both DL and UL, is $0.5 \mathrm{~ms}$ for URLLC and $4 \mathrm{~ms}$ for eMBB, whereas shall be no worse than $10 \mathrm{~s}$ for infrequent small packets. The target for mobility interruption time is 0 ms. The reliability requirement for URLLC is $1-10^{-5}$ with a user plane latency of $1 \mathrm{~ms}$, and $1-10^{-5}$ for eV2X (enhanced Vehicle to everything) with a user plane latency of 3-10 ms. The target for link budget is $164 \mathrm{~dB}$. The target UE battery life for mMTC should be beyond 10 years (sending one packet per day in extreme coverage). The TRxP spectrum efficiency shall be 3 times higher than that of IMT-Advanced for the first four deployment scenarios with eMBB. Both the user experienced data rate and the 5 th percentile user spectrum efficiency shall also be three times higher than that of IMT-Advanced. The target connection density is $1,000,000$ devices $/ \mathrm{km}^{2}$ in urban environment. The target maximum user speed is $500 \mathrm{~km} / \mathrm{h}$. 


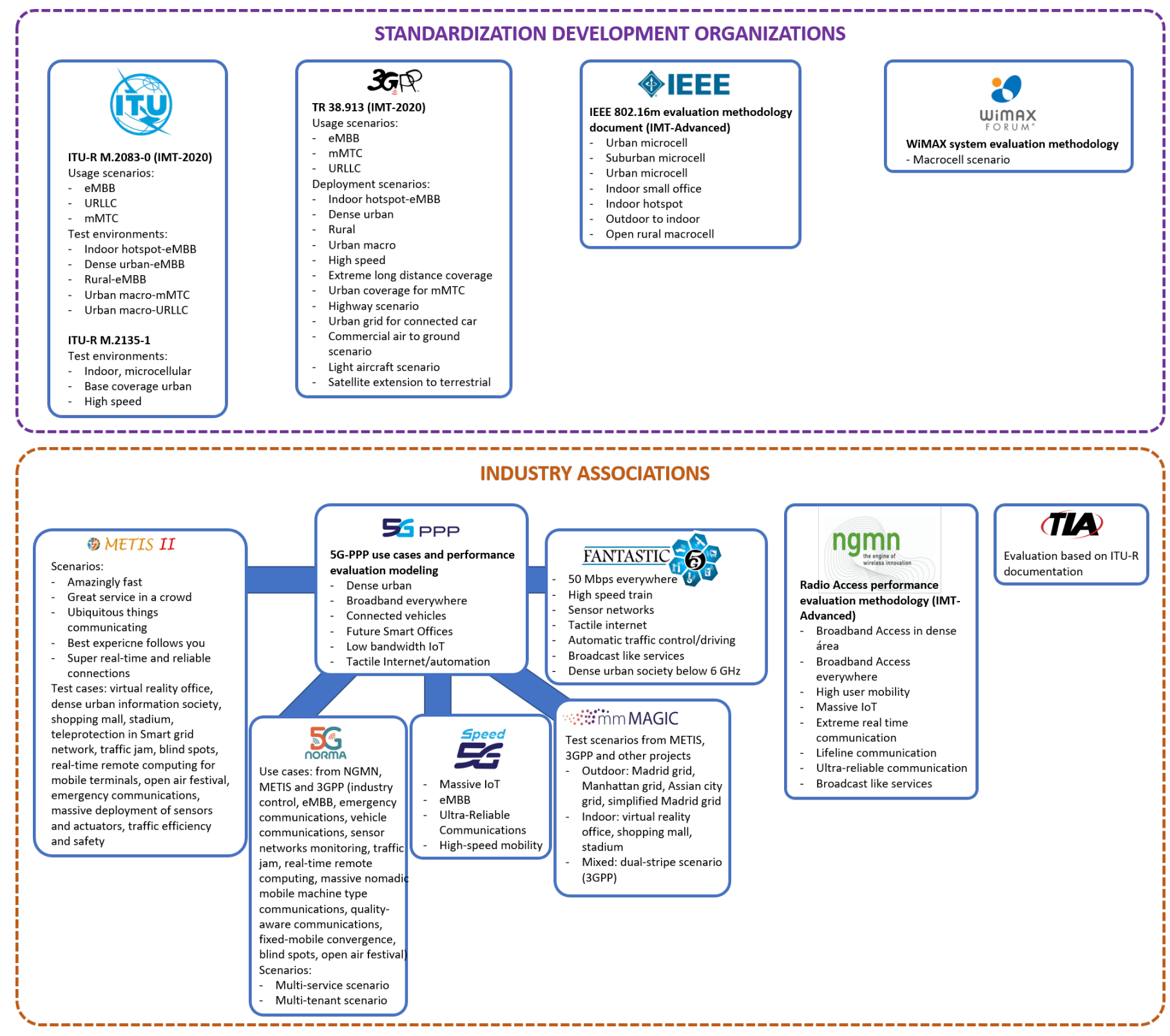

Figure 9: Summary of usage scenarios proposed by main SDOs and industry associations.

It is also proposed that at least $1 \mathrm{GHz}$ aggregated bandwidth shall be supported.

Report 3GPP TR 37.910 [52] provides self evaluation results towards IMT-2020 submission to ITU-R WP 5D. The use cases from IMT-2020 are considered: eMBB (indoor hotspot, dense urban, and rural), URLLC and mMTC. Results include average spectral efficiency, peak data rate, user experienced data rate, area traffic capacity, and latency. For the evaluation, link level assumptions are given but no traffic models are defined (only full buffer for New Radio (NR) and ITU models for mMTC).

Within 4G, report 3GPP TR 36.814 [53] presented the further advancements for E-UTRA (LTE-Advanced) to fulfill the requirements on IMT-Advanced. The simulation model presented in its Annex A identifies two types of simplified traffic models for non-real time services, the well-known full buffer traffic model and FTP (File Transfer Protocol) traffic models 1 and 2, which are summarized in Table IV. Due to its simplicity, these models have been largely used in the literature. The details of the self-evaluation results are defined in document 3GPP TSG RAN1\#59 R1-094954 [54]. Although these models are highly detailed, to the best of our knowledge, they have almost not been used in the literature.

Additionally, document 3GPP TSG-RAN1\#48 R1-070674 [55] presents the evaluation cases and the corresponding metrics to verify the performance of the LTE physical layer, including more complex traffic models for some of the most relevant services, i.e. FTP, web-browsing, video streaming, gaming and VoIP traffic models. Table $\mathrm{V}$ summarizes the characterization of these traffic patterns.

Other relevant traffic types are depicted in different 3GPP specifications. For example, Machine-to-Machine is studied in 3GPP TR 37.868 [56]. The study includes a load analysis 
Table III: Summary of 3GPP deployment scenarios

\begin{tabular}{|c|c|}
\hline Name & Scenario \\
\hline \multirow{4}{*}{$\begin{array}{l}\text { Indoor } \\
\text { hotspot- } \\
\text { eMBB }\end{array}$} & Description: offices and/or shopping malls \\
\hline & Environment: indoor floor (open office) \\
\hline & Users: 10 users per TRxP, indoor, $3 \mathrm{~km} / \mathrm{h}$ \\
\hline & Deployment: 12 TRxPs per $120 \mathrm{~m} \times 50 \mathrm{~m}(\mathrm{ISD}=20 \mathrm{~m})$ \\
\hline \multirow{4}{*}{$\begin{array}{l}\text { Dense ur- } \\
\text { ban }\end{array}$} & Description: city centres and dense urban areas \\
\hline & $\begin{array}{l}\text { Environment: high user densities and traffic loads, outdoor } \\
\text { and outdoor-to-indoor coverage }\end{array}$ \\
\hline & $\begin{array}{l}\text { Users: } 10 \text { users per TRxP, } 80 \% \text { indoor }(3 \mathrm{~km} / \mathrm{h}), 20 \% \\
\text { outdoor }(30 \mathrm{~km} / \mathrm{h})\end{array}$ \\
\hline & $\begin{array}{l}\text { Deployment: macro layer with ISD }=200 \mathrm{~m} \text {, micro layer with } \\
3 \text { TRxPs (outdoor) per macro TRxP }\end{array}$ \\
\hline \multirow[t]{4}{*}{ Rural } & Description: larger and continuous coverage \\
\hline & Scenario: rural environment \\
\hline & Users: 10 users per TRxP, $50 \%$ outdo \\
\hline & Deployment: regular grid with ISD $=1732 \mathrm{~m}$ or $5000 \mathrm{~m}$ \\
\hline \multirow{5}{*}{$\begin{array}{l}\text { Urban } \\
\text { macro }\end{array}$} & Description: city \\
\hline & Scenario: urban environment \\
\hline & Users: 10 users per TRxP, $20 \%$ \\
\hline & \\
\hline & Deployment: regular grid $(\mathrm{ISD}=500 \mathrm{~m})$ \\
\hline \multirow{5}{*}{$\begin{array}{l}\text { High } \\
\text { speed }\end{array}$} & Description: high speed trains \\
\hline & Scenario: track in high speed trains \\
\hline & Users: $100 \%$ of users in train, 300 UEs \\
\hline & gers ner train \\
\hline & $\begin{array}{l}\text { Deployment: ISD } 1732 \mathrm{~m} \text { between RRH sites, with two } \\
\text { TRxPs per RRH site (following the track) }\end{array}$ \\
\hline \multirow{5}{*}{$\begin{array}{l}\text { Extreme } \\
\text { long } \\
\text { distance } \\
\text { coverage }\end{array}$} & Description: very large areas with low density of users \\
\hline & Scenario: rural environn \\
\hline & Users: depending on the target user experience $\mathrm{d}$ \\
\hline & $\begin{array}{l}\text { Mbps while stationary and } 384 \mathrm{kbps} \text { while moving); up to } \\
160 \mathrm{~km} / \mathrm{h}\end{array}$ \\
\hline & Deployment: isolated cell with $100 \mathrm{~km}$ range \\
\hline \multirow{11}{*}{$\begin{array}{l}\text { Urban } \\
\text { coverage } \\
\text { for } \\
\text { massive } \\
\text { MTC } \\
\text { Highway } \\
\text { scenario }\end{array}$} & Descr \\
\hline & \\
\hline & Users: $20 \%$ outdoor in cars $(100 \mathrm{~km} / \mathrm{h})$ or users $(3 \mathrm{~km} / \mathrm{h})$, \\
\hline & Deployment: macro with ISD $=1732$ or $500 \mathrm{~m}$ \\
\hline & Description: vehicles in highways with high speed \\
\hline & \\
\hline & in vehicles, with an inter-vehicle dista \\
\hline & or $1 \mathrm{sec} *$ average vehicle \\
\hline & 50 messages per second \\
\hline & Deploymen \\
\hline & $\begin{array}{l}+ \text { RSUs (Roadside Unit, i.e. an eNB or UE with V2X } \\
\text { communications, ISD }=50 \text { or } 100 \mathrm{~m} \text { ) }\end{array}$ \\
\hline \multirow{6}{*}{$\begin{array}{l}\text { Urban } \\
\text { grid for } \\
\text { con- } \\
\text { nected } \\
\text { car }\end{array}$} & Description: urban area with highly density of vehicles \\
\hline & Scenario: urban grid model (1299 m x 750 m with 9 blocks \\
\hline & $\begin{array}{l}(433 \mathrm{~m} \times 250 \mathrm{~m}) \text { with car lanes ( } 2 \text { lanes per direction) and } \\
\text { pedestrian/bicycle sidewalks placed around the block) }\end{array}$ \\
\hline & Users: vehicles with speeds of 15,60 or $120 \mathrm{~km} / \mathrm{h}(50$ or 10 \\
\hline & $\begin{array}{l}\text { messages/sec depending on speed), inter-vehicle distance of } \\
2.5 \mathrm{sec} * \text { vehicle speed }\end{array}$ \\
\hline & $\begin{array}{l}\text { Deployment: macro only (ISD }=500 \mathrm{~m} \text { ) or macro }+ \text { RSUs } \\
\text { (placed at intersections, or with ISD }=50 \text { or } 100 \mathrm{~m} \text { ) }\end{array}$ \\
\hline \multirow{4}{*}{$\begin{array}{l}\text { Commercial } \\
\text { air to } \\
\text { ground } \\
\text { scenario }\end{array}$} & Description: mobile services for commercial aircrafts \\
\hline & $\begin{array}{l}\text { Scenario: services for both humans and machines inside a } \\
\text { commercial aircraft }\end{array}$ \\
\hline & Users: speed up to $1000 \mathrm{~km} / \mathrm{h}$ and altitude up to $15 \mathrm{~km}$ \\
\hline & $\begin{array}{l}\text { Deployment: macro cells with very large area coverage (up } \\
\text { to } 100 \mathrm{~km} \text { ) + relay in aircraft (aggregation point) }\end{array}$ \\
\hline \multirow{4}{*}{$\begin{array}{l}\text { Light air- } \\
\text { craft sce- } \\
\text { nario }\end{array}$} & Description: mobile services for small air planes \\
\hline & $\begin{array}{l}\text { Scenario: services for both humans and machines inside a } \\
\text { small air plane }\end{array}$ \\
\hline & $\begin{array}{l}\text { Users: up to } 6 \text { users per airplane, with up to } 370 \mathrm{~km} / \mathrm{h} \text { and } \\
\text { an altitude of up to } 3 \mathrm{~km}\end{array}$ \\
\hline & $\begin{array}{l}\text { Deployment: macro cells with very large area coverage (up } \\
\text { to } 100 \mathrm{~km} \text { ) without relays }\end{array}$ \\
\hline & Description: no terrestrial services are available \\
\hline extension & Scenario: roadways and rural areas \\
\hline & Users: $100 \%$ outdoors \\
\hline terrestrial & Deployment: GEO and LEO satellites \\
\hline
\end{tabular}

Table IV: Summary of 3GPP simplified traffic models for non-real time services

\begin{tabular}{|c|c|}
\hline Parameter & Statistical characterization \\
\hline \multicolumn{2}{|r|}{ Full buffer } \\
\hline Number of users & Constant during the simulation \\
\hline Data per user & Infinite \\
\hline \multicolumn{2}{|r|}{ FTP model 1} \\
\hline Number of users & Poisson distributed arrival rate $\lambda$ \\
\hline Data per user $S$ & $\begin{array}{l}\text { Each user downloads one file of fixed size } \\
S \text { (2Mbytes, optionally } 0.5 \text { Mbytes to speed-up } \\
\text { simulations) }\end{array}$ \\
\hline \multicolumn{2}{|r|}{ FTP model 2} \\
\hline Number of users & Constant $K$ during the simulation \\
\hline Data per user & $\begin{array}{l}\text { Each user downloads one file and waits an } \\
\text { exponentially distributed reading time } D \text { before } \\
\text { requesting the next file }\left(f_{D}=\lambda e^{-\lambda D}, D \geq\right. \\
0, \lambda=0.2 \text {, i.e. the average } D \text { is } 5 \text { seconds })\end{array}$ \\
\hline
\end{tabular}

for smart electric metering, fleet management, and earthquake monitoring applications. From this analysis, two traffic models are proposed which are summarized in Table VI. The amount of data transmitted per arrival is not included in the traffic models definition, although the evaluation assumes one packet of 200 bytes (+UDP/IP headers). Based on this report, 3GPP TR 36.888 [57] also includes two traffic models for MTC, one for regular reporting and another one for triggered reporting, summarized in Table VII.

Additionally, document 3GPP TSG-RAN WG2\#68-bis R2100204 [58] includes a list for some M2M services with their typical traffic characteristics, including session density, bytes in a session, deployment, mobility and machines $/ \mathrm{km}^{2}$, although not clearly specified. These services are summarized in Table VIII. This document also includes session level and packet level modeling, defining three cases for the session initiation time: periodic, random (following an exponential distribution, i.e. $p(t<T)=1-e^{-\lambda T}, T \geq 0$ ), or mixed. In the third case, the session is usually initiated periodically but may also be triggered by random events, so the session can be described by adding up one or several periodical processes and one or several Poisson processes. From the packet level point of view, in pure M2M services, the transmitted packet series inside a session usually is predefined, i.e. the packet number, sizes and intervals are fixed. In some M2M services where human input is present (interactive session), there may be different types of sessions, but the packet number, sizes and intervals of each type are still predefined.

As an example, [58] includes a typical smart metering service with metering data report, load control and alarm. The metering data are reported every hour (periodical process), the load control and alarm events take place randomly (two Poisson processes with average session intervals of 12 and 1000 hours, respectively). Each metering report includes only one 100 bytes packet, control sessions contains one 10 bytes packet and alarm messages include one 50 bytes packet.

Another example of application is D2D communications. Report 3GPP TR 36.843 [59] presents the evaluation methodology for D2D proximity services, including scenarios and traffic models. Different layout options are considered, using a hexagonal grid with 19 or 7 macro sites (urban macro scenario) mixed with indoor hotspot zones or dual stripes of 
apartments. The number of active users per cell area are 25 (general scenario) or 10 (public safety scenario), with a total of 150 users for discovery per cell. This report considers full buffer, VoIP and FTP2 (from [53]) for traffic models, assuming file sizes of 10 KBytes and, for VoIP, a source rate of 12.2 kbps with one frame every $20 \mathrm{~ms}$, a voice activity factor of $75 \%$, exponentially distributed talk spurts with a mean of 2.5 $\mathrm{s}$, and payloads of 41 bytes (with header compression) or 70 bytes (without header compression).

Table V: Summary of 3GPP traffic models

\begin{tabular}{|c|c|}
\hline Parameter & Statistical characterization \\
\hline & FTP traffic \\
\hline \multirow[t]{2}{*}{ File size $S$} & Truncated lognormal distribution (max 5Mbytes) \\
\hline & $\begin{array}{l}f_{x}=\frac{1}{\sqrt{2 \pi} \sigma x} e^{\frac{-(\ln x-\mu)^{2}}{2 \sigma^{2}}}, x>0, \sigma=0.35 \\
\mu=14.45\end{array}$ \\
\hline \multirow[t]{2}{*}{ Reading time $D$} & $\begin{array}{l}\text { Exponential distribution } \\
f_{x}=\lambda e^{-\lambda x}, x>0, \lambda=0.006\end{array}$ \\
\hline & Web-browsing traffic \\
\hline Main object size & Truncated lognormal \\
\hline & 100bytes, $\max 2$ Mbytes, $\sigma=1.37, \mu=8.37$ \\
\hline $\begin{array}{l}\text { Embedded object } \\
\text { size } S_{E}\end{array}$ & $\begin{array}{l}\text { Truncated lognormal distribution: min 50bytes, } \\
\text { max 2Mbytes, } \sigma=2.36, \mu=6.17\end{array}$ \\
\hline \multirow{3}{*}{$\begin{array}{l}\text { Embedded } \\
\text { objects per page } \\
N_{D}\end{array}$} & Truncated Pareto distribution ( $\max 53$ ) \\
\hline & $\begin{array}{l}f_{x}=\frac{\alpha_{k}^{\alpha}}{\alpha+1}, k \leq x<m, f_{x}=\left(\frac{k}{m}\right)^{\alpha}, x= \\
m, \alpha=1 . k=2, m=55\end{array}$ \\
\hline & $\begin{array}{l}\text { (subtract } k \text { from the random value to obtain } \\
N_{D} \text { ) }\end{array}$ \\
\hline time $D$ & Exponential distribution: $\lambda=0.033$ \\
\hline \multirow[t]{2}{*}{ Parsing time $T_{P}$} & Exponential distribution: $\lambda=7.69$ \\
\hline & Video streaming traffic \\
\hline \multirow{3}{*}{$\begin{array}{l}\text { Inter-arrival time } \\
\text { between frames } \\
\text { Packets per frame } \\
\text { Packet size }\end{array}$} & Deterministic: $100 \mathrm{~ms}$ (based on 10fps) \\
\hline & Deterministic: 8 packets per frame \\
\hline & $\begin{array}{l}\text { Truncated Pareto distribution: } \alpha=1.2, k= \\
\text { 20bytes, } m=250 \text { bytes }\end{array}$ \\
\hline \multirow[t]{2}{*}{$\begin{array}{l}\text { Inter-arrival time } \\
\text { between packets } \\
\text { in a frame }\end{array}$} & $\begin{array}{l}\text { Truncated Pareto distribution: } \alpha=1.1, k= \\
2.5 \mathrm{~ms}, m=12.5 \mathrm{~ms}\end{array}$ \\
\hline & Gaming traffic \\
\hline \multirow{5}{*}{$\begin{array}{l}\text { UL initial packet } \\
\text { arrival } \\
\text { UL packet arrival } \\
\text { UL packet size }\end{array}$} & $\begin{array}{l}\text { Uniform distribution } \\
f_{x}=\frac{1}{b-a}, a \leq x \leq b, a=0, b=40 \mathrm{~ms}\end{array}$ \\
\hline & $\begin{array}{l}\text { Deterministic: } 40 \mathrm{~ms} \\
\text { Deter }\end{array}$ \\
\hline & Largest extreme value distribution \\
\hline & $\begin{array}{l}f_{x}=\frac{1}{b} e^{-\frac{x-a}{b}} e^{-e^{-\frac{x-a}{b}}}, a=45 \text { bytes, } b= \\
5.7 \text { bytes }\end{array}$ \\
\hline & 2 bytes UDP header after header compression \\
\hline $\begin{array}{l}\text { DL initial packet } \\
\text { arrival }\end{array}$ & Uniform distribution: $a=0, b=40 \mathrm{~ms}$ \\
\hline DL packet arrival & $\begin{array}{l}\text { Largest extreme value distribution: } a=55 \mathrm{~ms} \text {, } \\
b=6 \mathrm{~ms}\end{array}$ \\
\hline DL packet size & $\begin{array}{l}\text { Largest extreme value distribution: } a= \\
120 \text { bytes, } b=36 \text { bytes ( } 2 \text { bytes UDP header) }\end{array}$ \\
\hline & VoIP traffic \\
\hline Codec & $\begin{array}{l}\text { RTP AMR } 12.2 \text { (source rate 12.2kbps) with } \\
\text { encoder frame duration } T=20 \mathrm{~ms}\end{array}$ \\
\hline \multirow[t]{2}{*}{$\begin{array}{l}\text { Voice } \\
\text { model }\end{array}$} & $\begin{array}{l}\text { Simple 2-state Markov model with the following } \\
\text { parameters: }\end{array}$ \\
\hline & $\begin{array}{l}\text { Voice Activity Factor (VAF) } \lambda=0.5 \text {, transition } \\
\text { probability from inactive to active state } c=0.01 \\
\rightarrow \text { transition probability from active to inactive } \\
\text { state } a=0.01 \text {, mean talk-spurt duration } \mu_{T S}=2 \mathrm{~s} \text {, } \\
\text { mean silence period duration } \mu_{S P}=2 \mathrm{~s}\end{array}$ \\
\hline \multirow[t]{2}{*}{ Packet size } & $\begin{array}{l}\text { VoIP frame of } 40 \text { bytes (including all overhead) } \\
\text { every } T=20 \mathrm{~ms}\end{array}$ \\
\hline & $\begin{array}{l}\text { Silence Insertion Descriptor (SID) packets of } \\
15 \text { bytes (including all overhead) every } 160 \mathrm{~ms} \\
\text { during silence }\end{array}$ \\
\hline
\end{tabular}

Although voice communications has been decreasing in the
Table VI: Summary of 3GPP traffic models for MTC (3GPP TR 37.868)

\begin{tabular}{|c|c|}
\hline Parameter & Statistical characterization \\
\hline \multicolumn{2}{|r|}{ Traffic model 1} \\
\hline $\begin{array}{l}\text { Number of MTC } \\
\text { devices }\end{array}$ & $1000,3000,5000,10000,30000$ \\
\hline $\begin{array}{l}\text { Arrival distribu- } \\
\text { tion }\end{array}$ & Uniform distribution over $T=60$ seconds \\
\hline $\begin{array}{l}\text { Application } \\
\text { packet size }\end{array}$ & 200 bytes \\
\hline \multicolumn{2}{|r|}{ Traffic model 2} \\
\hline $\begin{array}{l}\text { Number of MTC } \\
\text { devices }\end{array}$ & $1000,3000,5000,10000,30000$ \\
\hline $\begin{array}{l}\text { Arrival distribu- } \\
\text { tion }\end{array}$ & $\begin{array}{l}\text { Beta distribution over } T=10 \text { seconds }(\alpha=3, \beta=4) \\
f_{t}=\frac{t^{\alpha-1}(T-t)^{\beta-1}}{T^{\alpha+\beta-1} \operatorname{Beta}(\alpha, \beta)} \text {, where } \operatorname{Beta}(\alpha, \beta) \text { is } \\
\text { the Beta function }\end{array}$ \\
\hline $\begin{array}{l}\text { Application } \\
\text { packet size }\end{array}$ & 200 bytes \\
\hline
\end{tabular}

Table VII: Summary of 3GPP traffic models for MTC (3GPP TR 36.888)

\begin{tabular}{lc}
\hline Parameter & Statistical characterization \\
\hline \multicolumn{1}{c}{ Regular reporting for low-cost MTC (no mobility) } \\
\hline UL interval & 1 min (optional), 5 min, 30 min, 1 hour \\
Packets (bits) & 1000, optional 10000 \\
Mobility & Static, pedestrian (optional) \\
\hline \multicolumn{2}{c}{ Regular reporting for low-cost MTC (limited mobility) } \\
\hline UL interval & $5 \mathrm{~s}($ optional), $10 \mathrm{~s}, 30 \mathrm{~s}$ \\
Packets (bits) & 1000 \\
Mobility & Vehicular \\
\hline \multicolumn{2}{c}{ Triggered reporting (UL and DL) } \\
\hline Volume & 256 bits, 1000 bits \\
Inter-arrival time & Exponential with mean of 30 seconds \\
\hline
\end{tabular}

last years compared to data traffic (now it represents only around $2 \%$ of the total mobile traffic [60]), voice remains the principle service for most subscribers. Therefore, voice quality continues to be a major factor to determine what is the subscriber's perception regarding a particular operator. For that reason, current mobile networks are incorporating changes to improve the voice service in networks that are initially recognized as "data oriented" networks [61]. One example is VoLTE (Voice over LTE) in current 4G networks.

Due to the way humans talk with each other, many works (e.g. [62] [63] [64] [65] [66] [67] [68] [69] [70] [71]) utilize a simple on/off model for voice activity, despite of being very old [72]. Even nowadays, as previously commented, the on/off model is used by the 3GPP for the evaluation of LTE [55] (see Fig. 10).

Regarding voice activity, $3 \mathrm{GPP}$ uses a VAF of $50 \%$ (i.e. each subscriber speaks during half of the time, being quiet the

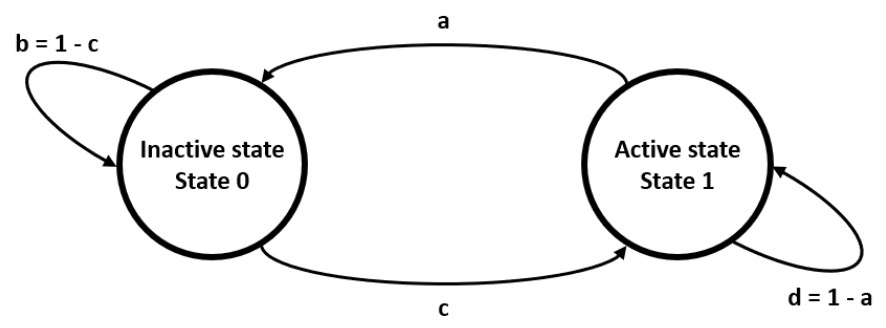

Figure 10: Two-state activity model for one speaker [55]. 
Table VIII: Summary of 3GPP traffic models for M2M services

\begin{tabular}{|c|c|}
\hline Parameter & Statistical characterization \\
\hline \multicolumn{2}{|r|}{ Smart metering } \\
\hline Description & Periodic or on-demand metering reports \\
\hline Session density & $<50$ times/day/metering device \\
\hline Bytes/session & Tens of bytes \\
\hline Deployment & Urban/suburban \\
\hline Mobility & Stationary \\
\hline Machines $/ \mathrm{km}^{2}$ & $<10000$ (urban), <1000 (suburban) \\
\hline \multicolumn{2}{|r|}{ Point of sale } \\
\hline Description & $\begin{array}{l}\text { Vending machine (transaction randomly trig- } \\
\text { gered) }\end{array}$ \\
\hline Session density & $<1000$ times/day \\
\hline Bytes/session & Hundreds of bytes \\
\hline Deployment & Urban \\
\hline Mobility & Stationary \\
\hline Machines $/ \mathrm{km}^{2}$ & $<1000$ \\
\hline \multicolumn{2}{|r|}{ Fleet management } \\
\hline Description & $\begin{array}{l}\text { Vehicles located periodically or on-demand; also } \\
\text { alarm and control data }\end{array}$ \\
\hline Session density & $<1000$ times/day \\
\hline Bytes/session & KBs \\
\hline Deployment & Urban/suburban \\
\hline Mobility & Mobile \\
\hline Machines $/ \mathrm{km}^{2}$ & $<5000$ \\
\hline \multicolumn{2}{|r|}{ Telemedicine } \\
\hline Description & $\begin{array}{l}\text { Periodical patient monitoring; also urgent calls } \\
\text { or some control data }\end{array}$ \\
\hline Session density & $<500$ times/day \\
\hline Bytes/session & Tens to hundreds of $\mathrm{KBs}$ \\
\hline Deployment & Urban/suburban \\
\hline Mobility & Stationary/mobile \\
\hline Machines $/ \mathrm{km}^{2}$ & $<1000$ \\
\hline \multicolumn{2}{|c|}{ Environment monitoring and control } \\
\hline Description & $\begin{array}{l}\text { Periodic or on-demand sensing data; also alarm } \\
\text { and control data }\end{array}$ \\
\hline Session density & $<1000$ times/day/sensor gateway \\
\hline Bytes/session & KBs (or MBs in special cases) \\
\hline Deployment & Urban/suburban \\
\hline Mobility & Stationary \\
\hline Machines $/ \mathrm{km}^{2}$ & $<1000$ (sensing data aggregated in a gateway) \\
\hline \multicolumn{2}{|r|}{ Home automation } \\
\hline Description & Home sensing and control, home security \\
\hline Session density & $<100$ times/day/home gateway \\
\hline Bytes/session & Hundreds of bytes \\
\hline Deployment & Urban/suburban \\
\hline Mobility & Stationary \\
\hline Machines $/ \mathrm{km}^{2}$ & $<10000$ (urban), <1000 (suburban) \\
\hline
\end{tabular}

other half) in document TSG-RAN1\#48 R1-070674 [55], but assumes a VAF of $40 \%$ for the performance evaluation of the AMR-WB speech codec [73]. This $40 \%$ is similar to the $39 \%$ specified by the ITU-T in 1993 [74], which utilizes an average ON (talk) duration of $\frac{1}{\lambda}=1.004 \mathrm{~s}$ and an average OFF (silence) duration of $\frac{1}{\mu}=1.587 \mathrm{~s}$. The derivation of parameters $a$ to $d$ is also explained in [55].

The latest version of the study on voice and video enhancement for LTE [75] considers the Adaptive Multi-Rate WideBand (AMR-WB [76]) and the Enhanced Voice Services (EVS [77]) codecs. These codecs adapt their rate during the conversation depending on current conditions. The standard defines the procedure to change the codec rate (using Codec Mode Request (CMR) messages) but it is up to the manufacturer to decide when the rate adaptation shall be triggered. Both AMR and EVS generate voice frames every $20 \mathrm{~ms}$ with a payload size which depends on the selected bit rate. During silence periods, a Silence Insertion Descriptor (SID) is sent every 160 ms with a payload of 39/40/48 bits (AMR-NB/AMRWB/EVS). 3GPP Technical Report 26.952 [78] comprises the performance characterization of EVS, including a comparison with both AMR-NB and AMR-WB.

In the case of AMR and AMR-WB, many papers e.g. [79] [80] [81] [82] [83] assume that the rate is fixed and no adaptation is performed (e.g. AMR-WB with $12.65 \mathrm{kbps}$ ). Similarly, it is typically assumed EVS-WB with $24.4 \mathrm{kbps}$ (since higher bit rates are not commonly implemented) with a VAF of $50 \%$.

\section{IEEE}

IEEE, the Institute of Electrical and Electronics Engineers, is an association dedicated to advancing innovation and technological excellence for the benefit of humanity, being the world's largest technical professional society [84].

Although IEEE has its own 5G Initiative [85], they are currently discussing about concepts, future options and roadmaps [86]; unfortunately, there is no clear picture about which current or future standards will be included on a proposal for IMT-2020. However, it is expected that IEEE 802.11 continues to enhance and develop new capabilities which can be RAN components of $5 \mathrm{G}$ [87]:

- 802.11ad/ay/aj: $60 \mathrm{GHz}$ band operation, applicable to short range and very high bandwidth operation (up to $176 \mathrm{Gbps})$.

- 802.11ah/ba: Sub $1 \mathrm{GHz}$ band (with a range up to $1 \mathrm{Km}$ ), applicable to low power machine type communications.

- 802.11ax: High efficiency WLANs (up to $14 \mathrm{Gbps}$ ), applicable to dense deployments.

Previously, IEEE was very active on 4G. In this regard, on October 2009, IEEE submitted to ITU-R Working Party 5D a "Candidate IMT-Advanced RIT based on IEEE 802.16". On October 2010, ITU-R assessment of six candidate submissions for the 4th generation of cellular systems resulted in two technologies, "LTE-Advanced" and "WirelessMANAdvanced" (IEEE Std $802.16 \mathrm{~m}$ ) being accorded the official designation of IMT-Advanced, qualifying them as true $4 \mathrm{G}$ technologies.

Document [88] proposes the baseline evaluation methodology for the IEEE $802.16 \mathrm{~m}$ standard. This document includes traffic models for web browsing, FTP, VoIP, near real time video streaming, and gaming traffic, which match those defined by 3GPP in [55] (with few changes in some parameters, see Tables V and IX). Specific path loss models are considered for different environments (e.g. urban macrocell, indoor small office, indoor hotspot, etc.) but no specific scenarios are defined.

In the case of VoIP, [88] also summarizes the main parameters for different voice codecs but suggests to assume AMR 12.2 kbps since "this model captures the worst case scenario", which is also the codec selected by 3GPP in [55]. In the case of web browsing, this document also incorporates an updated model based on measurements from the top 50 web sites taken on April 2007. Additionally, [88] describes traffic models for video telephony (based on MPEG 4 traces) and e-mail (based 
on an ON/OFF session model), which are also depicted in Table IX. Section 10.8 in [88] proposes different traffic mixes to be used in system evaluations. However, these traffic mixes are very simplistic, since most of them utilize only one service (e.g. "HTTP only") or a mixture of VoIP and full buffer traffic sources. The traffic mixed defined by NGMN in [89] (see Section III-G) is also included for liaison with NGMN.

For M2M communications, IEEE 802.16's Machine-toMachine Task Group includes in IEEE 802.16p-10/005 [91] usage scenarios, requirements, and standards changes needed for supporting M2M communications. This technical report identifies the following relevant M2M usage models: secured access and surveillance; tracking, tracing, and recovery; public safety; payment; health care; remote maintenance and control; metering; consumer devices; and retail. Besides, the traffic characteristics for Advanced Metering Infrastructure (AMI) is also provided as an example. Later, this Task Group elaborated a proposal for evaluation methodology for 802.16p [92] which includes traffic models for typical M2M services for in-home and city commercial M2M devices deployments. Tables X and XII summarize the traffic models for in-home and city commercial deployments, respectively. In the case of an inhome deployment, typical smart home appliances are included, such as the refrigerator, clothes washer/dryer, dishwasher, oven, etcetera. For the city commercial deployment, usual pieces of urban furniture are contemplated such as credit machines, traffic lights, roadway signs, etcetera. Deployments (cell radius and number of devices) are included in Tables XI and XIII.

\section{WiMAX Forum}

The WiMAX Forum is an industry-led, not-for-profit organization that certifies and promotes the compatibility and interoperability of broadband wireless products based upon IEEE Standard 802.16 [93].

The WiMAX Forum presented a system evaluation methodology for mobile WiMAX systems [94], including application traffic models (summarized in Table XIV) for: Internet games, VoIP, video conference, PTT (Push-to-Talk), music/speech, video clip, movie streaming, MBS (Multicast Broadcast Services), IM (Instant Messaging), web browsing, e-mail, telemetry, FTP, P2P (Peer-to-Peer), VPN (Virtual Private Network) and near real-time video. These application traffic models include user level and IP packet level models. The former considers user behavior interactions in an application, whereas the later contemplates packet size and packet interarrival time distributions at the IP layer. This document only considers a macrocell scenario with 19 hexagonal cells. Since this document was intended for WiMAX (which fulfills the requirements for IMT-Advanced), these models are not used in the current literature.

\section{E. TIA}

The Telecommunications Industry Association (TIA) [95] is the leading trade association representing the global information and communications technology (ICT) industry through standards development, policy initiatives, business
Table IX: Summary of IEEE $802.16 \mathrm{~m}$ traffic models

\begin{tabular}{l}
\hline Statistical characterization \\
\hline Web-browsing traffic \\
\hline Same statistical characterization as 3GPP (see Table V) \\
Updated model (Appendix P in [88]): this model separates the UL \\
and DL traffic and maintains the same reading and parsing times. \\
$U L:$ main object size with truncated lognormal distribution (min. 100 \\
bytes, max. 100 Kbytes, $\sigma=1.37, \mu=8.35$ ), embedded object \\
size with truncated lognormal distribution (min. 50 bytes, max. 100 \\
Kbytes, $\sigma=1.69, \mu=7.53$ ), and number of embedded objects per \\
page with truncated Pareto distribution (max. 53, $\alpha=1.1, k=2$, \\
$m=55$ ) \\
$D L:$ main object size with truncated lognormal distribution (min. 1290 \\
bytes, max. 0.25 Mbytes, $\sigma=0.8, \mu=10.55$ ), embedded object size \\
with truncated lognormal distribution (min. 5 bytes, max. 6 Mbytes, \\
$\sigma=1.97, \mu=7.1$ ), and number of embedded objects per page with \\
truncated Pareto distribution (max. 165, $\alpha=1.1, k=2, m=55$ ) \\
\hline FTP traffic \\
\hline Same statistical characterization as 3GPP (see Table V) \\
\hline VoIP traffic \\
\hline Same statistical characterization as $3 \mathrm{GPP}$ (see Table V), but with \\
different parameter values: \\
$\mu_{T S}=\mu_{S P}=1.25 s, a=c=0.016$
\end{tabular}

$\mu_{T S}=\mu_{S P}=1.25 s, a=c=0.016$

VoIP frame of 44-46bytes (including all overhead), SID packets of 18-20bytes (including all overhead) during silence

The main parameters (source bit rate, frame duration and information per frame) for typical voice codecs (EVRC, AMR-NB, GSM 6.10, G.711, G.723.1, and G.729A) are also included.

Near real time video streaming traffic

Same statistical characterization as "video streaming traffic" 3GPP (see Table V), except $k=40$ bytes for the packet size distribution

Video telephony traffic

Based on an Office Cam trace (from [90]) with high or medium quality. The video codec is MPEG-4 and it is transmitted over UDP. The main parameters are: 25 frames/sec, Group of Pictures with $\mathrm{N}=12$ and $\mathrm{M}=3$, display size is $176 \times 144$ pixels, color depth is 8 bits, the video quality is medium, the mean bandwidth is $110 \mathrm{kbps}$, the I frame size (bytes) follows a Weibull distribution $(\alpha=5.15$, $\beta=863$, shift $=3949, \mu=4742, \sigma=178, \min =4034, \max =5184)$, the $\mathrm{P}$ frame size (bytes) follows a lognormal distribution $(\mu=259$, $\sigma=134, \min =100, \max =1663$ ), and the B frame size (bytes) follows a lognormal distribution $(\mu=147, \sigma=74, \min =35, \max =882)$

Gaming traffic

Same statistical characterization as 3GPP (see Table V), except:

Uplink: packet arrival with largest extreme distribution $(a=40 \mathrm{~ms}$, $b=6 \mathrm{~ms})$ and packet size parameters ( $a=45$ bytes, $b=5.7$ bytes $)$

Downlink: packet arrival parameters $(a=50 \mathrm{~ms}, b=4.5 \mathrm{~ms})$ and packet size parameters ( $a=330$ bytes, $b=82$ bytes $)$

\section{E-mail traffic}

Traffic characterization: ON/OFF states. During ON-state an email could be transmitted or received, and during OFF-state a client is writing or reading an e-mail

E-mail protocol: POP3, MAPI

E-mail average header size: Deterministic distribution: $1 \mathrm{Kbyte}$

Number of e-mail received: Lognormal distribution: $\sigma=3.262$, $\mu=0.5277$

Number of e-mail sent: Lognormal distribution: $\sigma=2.364, \mu=$ 0.742

E-mail reading time: Pareto distribution: $\alpha=1.1, k=2 \mathrm{~s}, m=65 \mathrm{~s}$

E-mail writing time: Pareto distribution: $\alpha=1.1, k=2 \mathrm{~s}, m=125 \mathrm{~s}$

Size of e-mail received/sent without attachment: Cauchy distribution $f_{x}=\frac{A}{\pi\left((x-\mu)^{2}+1\right)}, \mu=22.7 \mathrm{Kbytes}, \mathrm{A}$ is selected to satisfy $90 \%$ tile $=80$ Kbytes

Size of e-mail received/sent with attachment: Cauchy distribution: $\mu=227$ Kbytes, $90 \%$-tile $=800$ Kbytes

Ratio of e-mail with attachment: Deterministic: $80 \%$ without attachment, $20 \%$ with attachment 
Table X: In-home M2M devices traffic parameters

\begin{tabular}{lllll}
\hline Device & $\begin{array}{l}\text { Transaction } \\
\text { rate }\end{array}$ & $\begin{array}{l}\text { Transaction Devices } \\
\text { size } \\
\text { (bytes) }\end{array}$ & $\begin{array}{l}\text { Distribution } \\
\text { hom }\end{array}$ & \\
\hline $\begin{array}{l}\text { Home security } \\
\text { system }\end{array}$ & $\begin{array}{l}1 \text { per } 10 \\
\text { min }\end{array}$ & 20 & 1 & Poisson \\
\hline $\begin{array}{l}\text { Elderly sensor } \\
\text { devices }\end{array}$ & 1 per min & 128 & 0.1 & Poisson/uniform \\
\hline Refrigerator & 1 per hour & 30 & 1 & Poisson/uniform \\
\hline $\begin{array}{l}\text { Clothes } \\
\text { washer }\end{array}$ & 1 per day & 8 & 1 & Poisson/uniform \\
\hline Clothes dryer & 1 per day & 8 & 1 & Poisson/uniform \\
\hline Dishwasher & 1 per day & 8 & 1 & Poisson/uniform \\
\hline Freezer & 1 per day & 30 & 1 & Poisson/uniform \\
\hline Stove/oven & 1 per day & 8 & 1 & Poisson/uniform \\
\hline Microwave & 1 per day & 8 & 1 & Poisson/uniform \\
\hline Coffee maker & 1 per day & 8 & 1 & Poisson/uniform \\
\hline Toaster oven & 1 per day & 8 & 1 & Poisson/uniform \\
\hline $\begin{array}{l}\text { Plug in elec- } \\
\text { tric vehicles in } \\
\text { smart grids }\end{array}$ & $\begin{array}{l}1 \text { per } 1.15 \\
\text { hours }\end{array}$ & 97.6 & 2 & Poisson/uniform \\
\hline Smart meter & $\begin{array}{l}1 \text { per } 2.5 \\
\text { hours }\end{array}$ & 2017 & 3 & Poisson/uniform \\
\hline
\end{tabular}

Table XI: Average home numbers in a cell

\begin{tabular}{lllll}
\hline Scenario & $\begin{array}{l}\text { Max cell } \\
\text { radius } \\
(\mathbf{m})\end{array}$ & $\begin{array}{l}\text { Min cell } \\
\text { radius } \\
(\mathbf{m})\end{array}$ & $\begin{array}{l}\text { max no. } \\
\text { homes } \\
\text { within } \\
\text { cell }\end{array}$ & $\begin{array}{l}\text { min no. } \\
\text { homes } \\
\text { within cell }\end{array}$ \\
\hline $\begin{array}{l}\text { Urban (New } \\
\text { York city) }\end{array}$ & 1000 & 500 & 12077 & 3021 \\
\hline $\begin{array}{l}\text { Suburban } \\
\text { (Washington }\end{array}$ & 1500 & 1000 & 10456 & 4647 \\
D.C.) & & & & \\
\hline
\end{tabular}

Table XII: City commercial M2M devices traffic parameters

\begin{tabular}{llll}
\hline Device & $\begin{array}{l}\text { Transaction } \\
\text { rate }\end{array}$ & $\begin{array}{l}\text { Transaction } \\
\text { size (bytes) }\end{array}$ & Distribution \\
\hline $\begin{array}{l}\text { Credit machine } \\
\text { in grocery }\end{array}$ & $\begin{array}{l}1 \text { per 2 min- } \\
\text { utes }\end{array}$ & 24 & Poisson \\
\hline $\begin{array}{l}\text { Credit machine } \\
\text { in shop }\end{array}$ & $\begin{array}{l}1 \text { per half an } \\
\text { hour }\end{array}$ & 24 & Poisson \\
\hline Roadway signs & $\begin{array}{l}1 \text { per half a } \\
\text { minute }\end{array}$ & 1 & Uniform \\
\hline Traffic lights & 1 per minute & 1 & Uniform \\
\hline Traffic sensors & 1 per minute & 1 & Poisson \\
\hline $\begin{array}{l}\text { Movie rental ma- } \\
\text { chines }\end{array}$ & 1 per day & 152 & Poisson \\
\hline
\end{tabular}

Table XIII: City commercial facilities deployment

\begin{tabular}{lllllll}
\hline Scenario & $\begin{array}{l}\text { grocery } \\
\text { stores } \\
/ \mathbf{m}^{2}\end{array}$ & $\begin{array}{l}\text { shops } \\
\text { and } \\
\text { restau- } \\
\text { rants } \\
/ \mathbf{m}^{2}\end{array}$ & $\begin{array}{l}\text { roadway } \\
\text { signs } \\
/ \mathbf{m}^{2}\end{array}$ & $\begin{array}{l}\text { traffic } \\
\text { lights } \\
/ \mathbf{m}^{2}\end{array}$ & $\begin{array}{l}\text { traffic } \\
\text { sensors } \\
/ \mathbf{m}^{2}\end{array}$ & $\begin{array}{l}\text { movie } \\
\text { rental } \\
\text { ma- } \\
\text { chines } \\
/ \mathbf{m}^{2}\end{array}$ \\
\hline $\begin{array}{l}\text { Urban } \\
\text { (New }\end{array}$ & $2.09 \mathrm{e}-4$ & 0.0022 & $3.16 \mathrm{e}-4$ & $1.50 \mathrm{e}-5$ & $1.50 \mathrm{e}-5$ & $6.98 \mathrm{e}-5$ \\
$\begin{array}{l}\text { York } \\
\text { city) }\end{array}$ & & & & & & \\
\hline $\begin{array}{l}\text { Suburban } \\
\text { (Wash- }\end{array}$ & $2.31 \mathrm{e}-5$ & $3.49 \mathrm{e}-4$ & $9.43 \mathrm{e}-4$ & $1.14 \mathrm{e}-4$ & $1.14 \mathrm{e}-4$ & $1.15 \mathrm{e}-5$ \\
ington & & & & & & \\
D.C.) & & & & & & \\
\hline
\end{tabular}

Table XIV: Summary of WiMAX traffic models

\begin{tabular}{|c|c|}
\hline Parameter & Statistical characterization \\
\hline \multicolumn{2}{|c|}{ Internet game, e.g. Quake II (see Xbox Halo2 and Toon Town in [94]) } \\
\hline $\begin{array}{l}\text { Session } \\
\text { (hours) }\end{array}$ & $\begin{array}{l}\text { Extreme distribution }\left(F(x)=1-e^{-e^{(x-a) / b}},\right. \\
a=1, b=0.1) \text {, truncated }(0,2)\end{array}$ \\
\hline $\begin{array}{l}\text { Client to server } \\
\text { packet IAT (msec) }\end{array}$ & $\begin{array}{l}\text { Lower } 4.5 \%, x<18: \text { Extreme }(a=6.57 \text {, } \\
b=0.517) ; \text { Upper } 95.5 \%, x>=18 \text { : Extreme } \\
(a=37.9, b=7.22)\end{array}$ \\
\hline $\begin{array}{l}\text { Client to server } \\
\text { packet sizes (bytes) }\end{array}$ & Around 45 (see [94] for more details) \\
\hline Server to client packet & Lower $4.8 \%, x<60$ : Extreme $(a=58.2, b=$ \\
\hline IAT $(\mathrm{msec})$ & $\begin{array}{l}\text { 7.47); Upper } 95.2 \%, x>=60: \text { Normal }(a= \\
100, b=17.7)\end{array}$ \\
\hline $\begin{array}{l}\text { Server to client packet } \\
\text { sizes (bytes) }\end{array}$ & $\begin{array}{l}\text { Lower } 27.6 \%, x<55 \text { : Extreme }(a=46.7 \text {, } \\
b=4.39) ; \text { Upper } 72.4 \%, x>=55 \text { : Extreme } \\
(a=79.7, b=11.3)\end{array}$ \\
\hline \multicolumn{2}{|r|}{ VoIP } \\
\hline $\begin{array}{l}\text { Average call holding } \\
\text { time }\end{array}$ & Exponential: $\mu$ \\
\hline Voice codec & AMR (12.2kbps) \\
\hline Frame length & $20 \mathrm{msec}$ \\
\hline Talk spurt length & Exponential: $\mu=1026 \mathrm{~ms}$ \\
\hline Silence length & Exponential: $\mu=1171 \mathrm{~ms}$ \\
\hline Silence suppression & Yes \\
\hline Protocols & RTP/UDP/IP, with header compression \\
\hline Speech activity & $47.17 \%$ \\
\hline UL:DL ratio & $1: 1$ \\
\hline Total MAC PDU size & MAC header $(6$ bytes $)+$ compressed \\
\hline during a talk spurt & $\begin{array}{l}\text { RTP/UDP/IP header }(3 \text { bytes })+\text { voice packet } \\
(33 \text { bytes })=42 \text { bytes }\end{array}$ \\
\hline Total MAC PDU size & MAC header (6 bytes) + compressed \\
\hline during a silence & $\begin{array}{l}\text { RTP/UDP/IP header ( } 3 \text { bytes) + voice packet }(7 \\
\text { bytes) }=16 \text { bytes }\end{array}$ \\
\hline Average bandwidth & $9.25 \mathrm{kbps}$ (w/o HARQ), $9.71 \mathrm{kbps}$ (w/ HARQ \\
\hline usage at MAC layer & CRC 2 bytes) \\
\hline \multicolumn{2}{|c|}{ Video conference, e.g. H.264 with 320x240 pixels and 8-bit color depth } \\
\hline Session duration & $3600 \mathrm{sec}$ \\
\hline Protocols & ader compression \\
\hline Scene length & Lognormal $(\mu=5.1 \mathrm{sec}, \sigma=9.05 \mathrm{sec})$ \\
\hline Direction & Bidirectional (UL and DL) \\
\hline Group of Pictures & $\mathrm{N}=12$, \\
\hline Subsampling method & 4:1:1 \\
\hline $\begin{array}{l}\text { Mean bandwidth for } \\
\text { uncompressed stream }\end{array}$ & $23 \mathrm{Mbps}$ \\
\hline Compressed ratio & 13.95 \\
\hline I frame size & $=5441)$ \\
\hline$P$ frame size & Lognormal $(\mu=8552, \sigma=3422)$ \\
\hline B frame size & Lognormal $(\mu=6048, \sigma=2168)$ \\
\hline AR coefficient & $a_{1}=0.39, a_{2}=0.15, \sigma_{\epsilon}=4.36$ \\
\hline \multicolumn{2}{|r|}{ Push to talk (PPT) } \\
\hline Call type mix & $\begin{array}{l}90 \% \text { one-to-one, } 10 \% \text { group talk (avg. } 5 \text { per- } \\
\text { sons/group) }\end{array}$ \\
\hline Voice & AMR $(12.2 \mathrm{kbps})$ \\
\hline Speech activity & $40 \%$ \\
\hline Protocols & $\begin{array}{l}\text { SIP/RTP/UDP/IP, with header compression, } 10 \\
\text { voice frames }(100 \mathrm{msec}) \text { per RTP packet }\end{array}$ \\
\hline y timer expire & $15 \mathrm{sec}$ \\
\hline No. transactions & $\begin{array}{l}\text { Avg. } 2.5 \text { talk }+2.5 \text { listens for one-to-one, avg. } \\
1 \text { talk }+4 \text { listens for group }\end{array}$ \\
\hline Talk burst duration & Exponential $(\mu=6 \mathrm{sec})$ \\
\hline Each volley latency & $2.75 \mathrm{sec}$ \\
\hline \multicolumn{2}{|r|}{ Instant messaging (IM) } \\
\hline Considerations & $\begin{array}{l}\text { Only IM background traffic is consider due to } \\
\text { the very low user-generated events }\end{array}$ \\
\hline $\begin{array}{l}\text { Presence update or } \\
\text { status check }\end{array}$ & $\begin{array}{l}\text { Exchange } 4 \text { packets between client and server } \\
\text { every } 40 \text { seconds (see Fig. 3.9.2 in [94]) }\end{array}$ \\
\hline \multicolumn{2}{|r|}{ Music / speech } \\
\hline Session duration & $1800 \mathrm{sec}$ \\
\hline Bit & $128 \mathrm{kbps}$ \\
\hline Protocols & TCP \\
\hline Direction & DL on \\
\hline Frames/sec & 10 frames/sec \\
\hline
\end{tabular}


Table XIV: Summary of WiMAX traffic models (cont.)

\begin{tabular}{|c|c|}
\hline Parameter & Statistical characterization \\
\hline \multicolumn{2}{|r|}{ Video clip } \\
\hline Video characteristics & $\begin{array}{l}\text { H.264 with } 320 \times 240 \text { pixels with } 8 \text { bit color } \\
\text { depth and } 25 \mathrm{fps}\end{array}$ \\
\hline Length & $\begin{array}{l}\text { Truncated exponential }(\mu=15 \mathrm{sec}, \max =60 \\
\text { sec) }\end{array}$ \\
\hline Protocols & TCP \\
\hline Direction & Unidirectional (UL or DL) \\
\hline Subsampling method & $4: 1: 1$ \\
\hline $\begin{array}{l}\text { Mean uncompressed } \\
\text { frame size }\end{array}$ & 115 Kbytes \\
\hline Compression ratio & 13.95 \\
\hline \multicolumn{2}{|r|}{ Movie streaming } \\
\hline Video characteristics & $\begin{array}{l}\text { Similar to video conference, with the following } \\
\text { differences }\end{array}$ \\
\hline Direction & DL only \\
\hline Compression ratio & 13.22 \\
\hline I frame size & Lognormal $(\mu=17068, \sigma=7965)$ \\
\hline$P$ frame size & Lognormal $(\mu=9190, \sigma=7005)$ \\
\hline B frame size & Lognormal $(\mu=6839, \sigma=5323)$ \\
\hline \multicolumn{2}{|r|}{ MBS } \\
\hline Video characteristics & $\begin{array}{l}\text { Similar to video conference, with the following } \\
\text { differences }\end{array}$ \\
\hline Direction & DL only \\
\hline Compression ratio & 6.87 \\
\hline I frame size & Lognormal $(\mu=59025, \sigma=6697)$ \\
\hline$P$ frame size & Lognormal $(\mu=29933, \sigma=6990)$ \\
\hline B frame size & Lognormal $(\mu=19658, \sigma=5737)$ \\
\hline \multicolumn{2}{|r|}{ Web browsing } \\
\hline Considerations & $\begin{array}{l}\text { Two models are included: the first one with } \\
\text { the below parameters, and the second one from } \\
\text { 3GPP (see Table V) }\end{array}$ \\
\hline No. pages per session & Lognormal $($ mean $=17$ pages, $\mathrm{std}=22$ pages $)$ \\
\hline Page request size & Constant ( 350 bytes) \\
\hline $\begin{array}{ll}\text { Main } & \text { object } \quad \text { size } \\
\left(S_{M}\right) & \end{array}$ & $\begin{array}{l}\text { Truncated lognormal }(\text { mean }=52390 \text { bytes, } \\
\text { std=49591 bytes, min }=1290 \text { bytes, } \max =0.25 \\
\text { Mbytes) }\end{array}$ \\
\hline $\begin{array}{l}\text { Embedded object size } \\
\left(S_{E}\right)\end{array}$ & $\begin{array}{l}\text { Truncated lognormal }(\text { mean }=8551 \text { bytes, } \\
\text { std }=59232 \text { bytes, } \min =5 \text { bytes, } \max =6 \text { Mbytes) }\end{array}$ \\
\hline $\begin{array}{l}\text { No. embedded objects } \\
\text { per page }\left(N_{d}\right)\end{array}$ & Truncated Pareto $($ mean $=51.1, \max =165)$ \\
\hline Reading time $\left(D_{p c}\right)$ & Exponential $($ mean $=30 \mathrm{sec})$ \\
\hline Parsing time $\left(T_{p}\right)$ & Exponential $($ mean $=0.13 \mathrm{sec})$ \\
\hline \multicolumn{2}{|r|}{ E-mail (POP3, MAPI) } \\
\hline Considerations & $\begin{array}{l}\text { Similar to the model from IEEE } 802.16 \mathrm{~m} \text { (see } \\
\text { Table IX) }\end{array}$ \\
\hline No. e-mail received & Lognormal $(m e a n=30$, std=17) \\
\hline No. e- & $4, \mathrm{std}=12)$ \\
\hline Reading time & Pareto $($ mean $=60 \mathrm{sec})$ \\
\hline Writing time & Pareto $($ mean $=120 \mathrm{sec})$ \\
\hline $\begin{array}{l}\text { Avg. e-mail header } \\
\text { size }\end{array}$ & Constant (1 Kbyte) \\
\hline E-mail size & 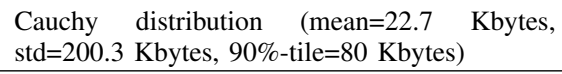 \\
\hline \multicolumn{2}{|r|}{ Telemetry } \\
\hline Message frequency & One every hour \\
\hline Message size & 10 bytes \\
\hline \multicolumn{2}{|r|}{ FTP } \\
\hline Considerations & From 3GPP (see Table V) \\
\hline \multicolumn{2}{|r|}{ P2P (file sharing) } \\
\hline Session duration & $1800 \mathrm{sec}$ \\
\hline Average DL bit rate & $500 \mathrm{kbps}$ \\
\hline Direction & DL only \\
\hline Protocol & TCP (FTP for the application layer) \\
\hline \multicolumn{2}{|r|}{ VPN } \\
\hline Considerations & $\begin{array}{l}\text { A brief analysis about VPN traffic using IPSec is } \\
\text { included, but it is recommended that the traffic } \\
\text { model should utilize traffic measurements from } \\
\text { the real target network. }\end{array}$ \\
\hline \multicolumn{2}{|r|}{ Near real-time video (NRTV) } \\
\hline Considerations & From 3GPP (see Table V) \\
\hline
\end{tabular}

opportunities, market intelligence and networking events. With support from hundreds of members, TIA enhances the business environment for companies involved in telecommunications, broadband, mobile wireless, information technology, networks, cable, satellite, unified communications, emergency communications and the greening of technology. TIA is accredited by ANSI.

Committee TR-45 was registered as an independent evaluation group for candidate radio interface technologies for the terrestrial components of the radio interface(s) for IMTAdvanced. The evaluation methodology is based on relevant ITU-R documentation (e.g. ITU-R M.2135 [32]). [96] presents the results for such evaluation. The system-level simulation assumptions used full-buffer data traffic to evaluate cell and cell-edge user spectral efficiency, and VoIP traffic (12.2 kbps codec with a $50 \%$ activity factor, with the same parameters as 3GPP, see Table V) to evaluate the VoIP capacity. No other traffic models were assumed for the evaluation of IMTAdvanced.

\section{F. $5 G P P P$}

The 5G Infrastructure Public Private Partnership [97] has been initiated by the EU Commission and industry manufacturers, telecommunications operators, service providers, SMEs and researchers. In the 5G PPP, the 5G Infrastructure Association (5G IA) represents the private side and the European Commission the public side. The 5G IA is committed to the advancement of $5 \mathrm{G}$ in Europe and to build global consensus on 5G. To this aim, the Association and its Members carry out a wide-range of activities in key strategic areas including standardization, frequency spectrum, $R \& D$, cooperation with other strategic industry sectors.

White paper [98] provides an overview of use cases and performance evaluation models that were developed for an early evaluation of different $5 \mathrm{G}$ radio access network concepts. It includes the following use case families, which have different type of requirements:

- Dense urban

- Broadband (50+Mbps) everywhere

- Connected vehicles

- Future smart offices

- Low bandwidth IoT (Internet of Things)

- Tactile internet/automation

These use case families are mapped onto the following vertical industries business cases:

- Automotive

- e-Health

- Energy

- Media \& entertainment

- Factories of the future

Section 4 of [98] includes the performance evaluation models proposed for simulations, including the models and use cases from METIS-II [99], FANTASTIC-5G [100], mmMAGIC [101], SPEED-5G [102] and 3GPP [47]. Network deployments include synthetic scenarios for indoor hotspot, urban macro, outdoor small cells, and rural macro, as well as realistic scenarios for indoor office, Madrid Grid, Future 
Home Environment, and Extended Suburban HetNet, which are mapped to specific use cases of the aforementioned projects. More details can be found in [98]. Table XV summarizes the traffic models included in [98], which will be discussed in this section, for the main use cases treated by $5 \mathrm{G}$ PPP: indoor, dense urban, broadband access everywhere, high speed, mMTC, vehicular safety and broadcast and moving hot spots.

Following subsections summarize the test environments and traffic models extracted from the major 5G PPP projects.

1) METIS: METIS [103], Mobile and wireless communications Enablers for Twenty-twenty (2020) Information Society, was an Integrated Project co-funded by the European Commission under the Seventh Framework Programme for research and development (FP7). The consortium was composed of 29 partners coordinated by Ericsson, including manufactures, network telecommunications operators, academic institutions, automotive industry and a research centre. The project started at November 2012 and finished at April 2015, and aimed at providing a foundation for a future mobile and wireless communications system for 2020 and beyond, paving the way for future standardization.

METIS proposes a 5G system [104] that integrates the following services:

- Evolved mobile broadband (eMBB)

- Massive Machine Communications (MCC)

- Vehicle to Vehicle, Device and Infrastructure (V2X)

- Ultra-Reliable Communications (URC)

METIS-II [99] built on the METIS project and aimed at providing the $5 \mathrm{G}$ collaboration framework within 5G PPP for a common evaluation of $5 \mathrm{G}$ radio access network concepts and preparing concerted action towards regulatory and SDOs. Started at July 2015 and with a duration of 24 months, METIS-II comprised partners from all regions with strong $5 \mathrm{G}$ $\mathrm{R} \& \mathrm{D}$ initiatives, including major international vendors, major operators, and key researchers. METIS-II also built on the previous 5G system concept, now considering three generic services (extreme mobile broadband, massive machine-type communication, and ultra-reliable machine-type communication), and four main enablers (a lean system control plane, a dynamic ran, localized contents and traffic flows, and a spectrum toolbox) [13].

The METIS project proposes 5 scenarios [107] [108] based on five challenges, namely "amazingly fast", "great service in a crowd", "ubiquitous things communicating", "best experience follows you" and "super real-time and reliable connections". Additionally, it further defines 12 test cases (TC1 - TC12) which contain challenges from one or more scenarios. The aim of the test cases is to describe different problems, including their requirements and the end-user expectations.

These test cases are further described in [105] and summarized in Table XVI, including the environment, network deployment, system load, traffic patterns and requirements for each use case. TCs include virtual reality office, dense cities, shopping malls, stadiums, traffic jams, open air festivals, emergency communications, massive deployment of sensors, traffic safety, etcetera. For the sake of readability, only requirements related to traffic volume, user data rate and latency are
Table XV: Summary of traffic models for 5G PPP performance evaluation

\begin{tabular}{l|l}
\hline Use case & Traffic model \\
\hline \multirow{3}{*}{ Indoor environment } & $\begin{array}{l}\text { METIS-II Virtual reality office: Full buffer, } \\
\text { bursty traffic FTP model 3 (file size = 3.5 MB, } \\
\text { varying IAT (InterArrival Time) }\end{array}$ \\
\cline { 2 - 2 } SPEED-5G Future home environment: Full \\
buffer, 20 Mb packet generated according to \\
a Poisson process with mean IAT = 20ms, \\
UL/DL/D2D/no tx probability = 50/50/0/0 or \\
40/40/10/10
\end{tabular}

included [107]. Propagation and mobility models are included in [105]. Traffic generation models for the proposed traffic mixes are outlined in Table XVII. As shown, these models are rather simplistic since they are based on the well-known 3GPP FTP model 2, CBR (Constant Bit Rate) sources or VBR (Variable Bit Rate) sources with uniform packet size. Moreover, the reading time (e.g. for BUD and BAD traffic) is derived from traffic volume which is clearly a non-realistic assumption if user-level granularity is desired.

2) FANTASTIC-5G: FANTASTIC-5G [100] is the 5G-PPP project on $5 \mathrm{G}$ air interface below $6 \mathrm{GHz}$, aiming at concurrently supporting a wide range of use cases with a single modular air interface. For the development and evaluation of the proposed air interface, the following services have been considered [109]: mobile broadband, massive machine communications, mission critical communications, broadcast/multicast services, and vehicular communications.

Deliverable D2.1 [110] provides the guidelines for the system level simulations within this project. Seven use cases are 
Table XVI: Summary of METIS test cases

\begin{tabular}{|c|c|c|c|c|c|}
\hline Test case & Description & Scenario & User Requirements & System requirements & Traffic patterns \\
\hline $\begin{array}{l}\text { TC1 } \\
\text { Virtual real- } \\
\text { ity office }\end{array}$ & $\begin{array}{l}\text { An office with rooms, } \\
\text { cubicle offices and ta- } \\
\text { bles }\end{array}$ & $\begin{array}{l}\text { Environment: realistic office }\left(10 \times 20 \mathrm{~m}^{2}\right) \text { en- } \\
\text { vironmental model } \\
\text { Deployment: one main base station ceiling- } \\
\text { mounted }\end{array}$ & $\begin{array}{l}\text { Data rate: } 1 \mathrm{Gbps} \text { (UL and DL) with } \\
95 \% \text { availability, 5Gbps with } 20 \% \\
\text { availability, } 0.5 \mathrm{Gbps} \text { in busy period } \\
\text { Latency: } 10 \mathrm{~ms} \text { (MAC RTT) }\end{array}$ & $\begin{array}{l}\text { Connections: } 0.1 \mathrm{UEs} / \mathrm{m}^{2} \\
\text { Traffic: average } 100 \mathrm{Mbps} / \mathrm{m}^{2} \text {, peaks } \\
500 \mathrm{Mbps} / \mathrm{m}^{2} \text { DL and UL }\end{array}$ & $\begin{array}{l}\text { FTP-based model with varying } \\
\text { reading time }\end{array}$ \\
\hline $\begin{array}{l}\mathrm{TC} 2 \\
\text { Dense urban } \\
\text { information } \\
\text { society }\end{array}$ & $\begin{array}{l}\text { Future urban setting } \\
\text { with high traffic vol- } \\
\text { umes and high expe- } \\
\text { rienced data rates }\end{array}$ & $\begin{array}{l}\text { Environment: Madrid grid (an area of } \\
\text { 387mx552m) } \\
\text { Deployment: one single three-sector macro } \\
\text { station with } 12 \text { micro/pico cells }\end{array}$ & $\begin{array}{l}\text { Data rate: } 300(60) \text { Mbps DL(UL) with } \\
95 \% \text { availability, } 5(1) \text { Mbps DL(UL) in } \\
\text { busy period } \\
\text { Latency: }<0.5 \mathrm{~s} \text { for web and video start- } \\
\text { ing (E2E), }<2-5 \mathrm{~ms} \text { for augmented real- } \\
\text { ity (E2E), certain D2D discovery and } \\
\text { setup time requirements }\end{array}$ & $\begin{array}{l}\text { Connections: } \max 0.2 \mathrm{UEs} / \mathrm{m}^{2}, 75 \% \\
\text { of users are located indoor and } 25 \% \\
\text { outdoor } \\
\text { Traffic: } 700 \mathrm{Gpbs} / \mathrm{km}^{2} \quad \text { (DL+UL), } \\
500 \mathrm{Gbyte} / \mathrm{month} / \mathrm{subscriber} \text { (DL+UL) }\end{array}$ & $\begin{array}{l}40 \% \text { BUD traffic (6\% UL, } \\
34 \% \text { DL), } 40 \% \text { Non Real-Time } \\
\text { Video Traffic (NRT VT) (6\% } \\
\text { UL, 34\% DL), } 7.5 \% \text { BAD traf- } \\
\text { fic (1.5\% UL, 6\% DL), } 7.5 \% \\
\text { Real-Time Video Traffic (RT } \\
\text { VT) (1.5\% UL, } 6 \% \text { DL), traffic } \\
\text { generated by sensors 5\% }\end{array}$ \\
\hline $\begin{array}{l}\text { TC3 } \\
\text { Shopping } \\
\text { Mall }\end{array}$ & $\begin{array}{l}\text { Setting with a high } \\
\text { density of customers } \\
\text { and staff with high } \\
\text { traffic volumes, high } \\
\text { experienced data rates } \\
\text { and good availability }\end{array}$ & $\begin{array}{l}\text { Environment: } 300 \mathrm{~m} \times 200 \mathrm{~m} \text { mall area with } \\
\text { stores and passage ways } \\
\text { Deployment: pico and femto cells placed } \\
\text { regularly along the passage way }\end{array}$ & $\begin{array}{l}\text { Data rate: } 300(60) \text { Mbps } \quad \text { DL(UL) } \\
\text { under below availability, 20Mbps } \\
\text { (DL and UL) for continuous traffic, } \\
1.7(0.7) \text { Mbps DL(UL) in busy period } \\
\text { Latency: user plane RTT }<5 \mathrm{~ms} \text {, control } \\
\text { plane for sensor network attach }<5 \mathrm{~ms}\end{array}$ & 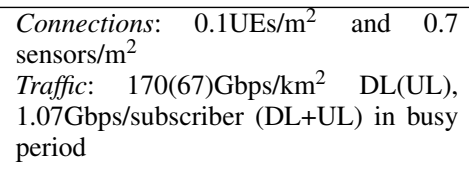 & $\begin{array}{l}\text { FTP-traffic model ( } 20 \mathrm{MB} \text { for } \\
\text { regular users and } 8 \mathrm{~KB} \text { for sen- } \\
\text { sors) }\end{array}$ \\
\hline $\begin{array}{l}\text { TC4 } \\
\text { Stadium }\end{array}$ & $\begin{array}{l}\text { A mass event with a } \\
\text { very high probability } \\
\text { of correlated demand } \\
\text { for data transfer }\end{array}$ & $\begin{array}{l}\text { Environment: stadium with ellipse shape } \\
\text { with } 105 \mathrm{~m} \times 150 \mathrm{~m} \text { of radii, covered with } \\
\text { a deck of height } 33 \mathrm{~m} \\
\text { Deployment: } 27 \text { small cells deployed on the } \\
\text { roof }\end{array}$ & $\begin{array}{l}\text { Data rate: } 0.3-20 \mathrm{Mbps} \text { DL+UL, } 0.3- \\
\text { 3Mbps DL+UL in busy period } \\
\text { Latency: } \mathrm{RTT}<5 \mathrm{~ms}\end{array}$ & $\begin{array}{l}\text { Connections: } 50000 \text { active users } \\
\text { Traffic: two cases (both with } \\
\left.\text { 9Gbytes/h/user, 0.1-10Mbps } / \mathrm{m}^{2}\right) \text { : } \\
\text { a) DL heavy traffic }+\mathrm{UL}+\text { optional } \\
\text { D2D traffic (ratio } 7: 1: 1) \text {, with transfers } \\
\text { of 50Mbytes files every 20s; b) UL } \\
\text { heavy traffic }+ \text { DL }+ \text { optional D2D } \\
\text { traffic (ratio } 1: 7: 1) \text {, with transfers } \\
\text { of } 75 \mathrm{Mbytes}(37.5 \mathrm{MBytes} \text { for D2D } \\
\text { traffic) files every 30s }\end{array}$ & $\begin{array}{l}\text { Video upload; mixture of } \\
\text { video traffic and BUD traffic }\end{array}$ \\
\hline $\begin{array}{l}\text { TC5 } \\
\text { Tele- } \\
\text { protection in } \\
\text { smart grid } \\
\text { network }\end{array}$ & $\begin{array}{l}\text { Smart grid network } \\
\text { with low latency } \\
\text { and high reliability } \\
\text { requirements }\end{array}$ & $\begin{array}{l}\text { Environment: } 3 \mathrm{GPP} \text { or TC2 models } \\
\text { Deployment: } 200,15 \text { and } 1 \text { substation per } \\
\mathrm{km}^{2} \text { in dense urban, urban and rural envi- } \\
\text { ronments, respectively }\end{array}$ & $\begin{array}{l}\text { Data rate: } 0.15-1.5 \mathrm{Mbps} \\
\text { Latency: } 8 \mathrm{~ms} \text { one trip time for event } \\
\text { triggered message }\end{array}$ & $\begin{array}{l}\text { Connections: } 1-1000 \text { per } \mathrm{km}^{2} \\
\text { No specific requirement for traffic vol- } \\
\text { ume }\end{array}$ & $\begin{array}{l}\text { Small net payloads (from } 200 \\
\text { to } 1521 \text { bytes) }\end{array}$ \\
\hline $\begin{array}{l}\text { TC6 } \\
\text { Traffic jam }\end{array}$ & $\begin{array}{l}\text { In-vehicle users that } \\
\text { utilize bandwidth- } \\
\text { demand services } \\
\text { during traffic jam } \\
\text { situations }\end{array}$ & $\begin{array}{l}\text { Environment: Madrid grid model (TC2) or } \\
\text { other Manhattan grid models for urban sce- } \\
\text { narios, a single road for motorways scenar- } \\
\text { ios } \\
\text { Deployment: base stations placed regularly } \\
\text { along the road (2-sector BSs with ISD of } 25 \\
\text { km for motorways) }\end{array}$ & $\begin{array}{l}\text { Data rate: } 100(20) \mathrm{Mbps} \text { DL(UL) with } \\
95 \% \text { availability } \\
\text { Latency: }<100 \mathrm{~ms}(\mathrm{E} 2 \mathrm{E})\end{array}$ & $\begin{array}{l}\text { Connections: } 4000 \text { per } \mathrm{km}^{2} \text {, max } \\
0.2 / \mathrm{m}^{2} \text { on the lane in traffic jam } \\
\text { Traffic: } 480 \mathrm{Gbps} / \mathrm{km}^{2} \text { DL+UL }(1000 \\
\text { vehicles per } \mathrm{km}^{2} \text {, with a maximum of } \\
4 \text { active users per vehicle) }\end{array}$ & $\begin{array}{l}\text { Traffic model defined for TC2 } \\
\text { for in-vehicle users }\end{array}$ \\
\hline
\end{tabular}


Table XVI: Summary of METIS test cases (cont.)

\begin{tabular}{|c|c|c|c|c|c|}
\hline Test case & Description & Scenario & User requirements & System requirements & Traffic patterns \\
\hline $\begin{array}{l}\text { TC7 } \\
\text { Blind spots }\end{array}$ & $\begin{array}{l}\text { E.g. rural areas } \\
\text { with sparse network } \\
\text { architecture or deeply } \\
\text { shadowed urban areas }\end{array}$ & $\begin{array}{l}\text { Environment: blind spots such as rural areas } \\
\text { or deeply shadowed urban areas } \\
\text { Deployment: vehicles equipped with relays } \\
\text { which can be integrated into the infrastruc- } \\
\text { ture of the operators (Madrid grid) }\end{array}$ & $\begin{array}{l}\text { Data rate: } 100(20) \text { Mbps DL(UL) with } \\
95 \% \text { availability in blind spots } \\
\text { Latency: }<100 \mathrm{~ms}\end{array}$ & $\begin{array}{l}\text { Connections: } 100-1000 \text { per } \mathrm{km}^{2} \\
\text { Traffic: } 12-120 \mathrm{Gbps} / \mathrm{km}^{2} \text { DL and UL } \\
\text { (rural-urban) }\end{array}$ & Same as TC2 \\
\hline $\begin{array}{l}\text { TC8 } \\
\text { Real-time } \\
\text { remote } \\
\text { computing } \\
\text { for mobile } \\
\text { terminals }\end{array}$ & $\begin{array}{l}\text { Access to remote } \\
\text { computing and cloud } \\
\text { facilities (high data } \\
\text { rates and low latency } \\
\text { for terminals with } \\
\text { mobility) }\end{array}$ & $\begin{array}{l}\text { Environment: same as TC2 } \\
\text { Deployment: same as TC2 }\end{array}$ & $\begin{array}{l}\text { Data rate: } 100(20) \mathrm{Mbps} \text { DL(UL) } \\
\text { Latency: }<10 \mathrm{~ms}(\mathrm{E} 2 \mathrm{E})\end{array}$ & $\begin{array}{l}\text { Connections: up to } 5 \text { active devices per } \\
\text { car, } 100 \mathrm{cars} / \mathrm{km}^{2}, 50 \text { per bus, } 300 \text { per } \\
\text { train } \\
\text { Traffic: } 60 \mathrm{Gbps} / \mathrm{km}^{2}\end{array}$ & Same as TC2 \\
\hline $\begin{array}{l}\text { TC9 } \\
\text { Open air fes- } \\
\text { tival }\end{array}$ & $\begin{array}{l}\text { Small rural area dur- } \\
\text { ing a few days with } \\
\text { lots of visitors }\end{array}$ & $\begin{array}{l}\text { Environment: small rural area of } 1 \mathrm{~km} \times 1 \mathrm{~km} \\
\text { Deployment: possible deployments: } 5,9 \text { or } \\
25 \text { base stations }\end{array}$ & $\begin{array}{l}\text { Data rate: } 30 \mathrm{Mbps} \text { (DL or UL), } 9 \mathrm{Mbps} \\
(\mathrm{DL} / \mathrm{UL}) \text { in busy period } \\
\text { Latency: }<1 \mathrm{~s} \text { for machine traffic, } 10- \\
50 \mathrm{~ms} \text { for user traffic, }<10 \mathrm{~min} \text { for delay } \\
\text { tolerant traffic }\end{array}$ & $\begin{array}{l}\text { Connections: } 0.1 \text { per } \mathrm{m}^{2} \text {, max } 4 \text { per } \\
\mathrm{m}^{2} \\
\text { Traffic: } 900 \mathrm{Gbps} / \mathrm{km}^{2} \quad \text { (DL+UL), } \\
\begin{array}{l}\text { 3.6Gbyte/subscriber } \mathrm{DL}+\mathrm{UL} \text { in busy } \\
\text { period }\end{array}\end{array}$ & 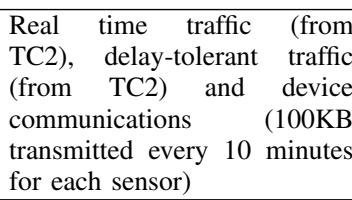 \\
\hline $\begin{array}{l}\text { TC10 } \\
\text { Emergency } \\
\text { communica- } \\
\text { tions }\end{array}$ & $\begin{array}{l}\text { After a natural disas- } \\
\text { ter in dense urban en- } \\
\text { vironment }\end{array}$ & $\begin{array}{l}\text { Environment: same as TC2 but after a nat- } \\
\text { ural disaster (no 3D buildings) } \\
\text { Deployment: macro cells with an inter site } \\
\text { distance (ISD) of } 5 \mathrm{~km}\end{array}$ & $\begin{array}{l}\text { No requirements regarding user data } \\
\text { rate or latency }\end{array}$ & $\begin{array}{l}\text { Connections: } 10 \mathrm{UEs} / \mathrm{km}^{2} \text { with } 10 \\
\text { voice calls and } 10 \mathrm{SMS} \text { during a week }\end{array}$ & $\begin{array}{l}\text { Voice traffic from survivors } \\
\text { and voice traffic between first } \\
\text { responders (rescue teams) }\end{array}$ \\
\hline $\begin{array}{l}\text { TC11 } \\
\text { Massive de- } \\
\text { ployment of } \\
\text { sensors and } \\
\text { actuators }\end{array}$ & $\begin{array}{l}\text { Large number of de- } \\
\text { vices which transmit } \\
\text { data occasionally }\end{array}$ & $\begin{array}{l}\text { Environment: } 3 \mathrm{GPP} \text { or TC2 models, } 300 \\
000 \text { devices per macro cell area ( } 3 \mathrm{GPP}) \text { or } \\
\text { per Madrid grid area (TC2) } \\
\text { Deployment: } 3 \mathrm{GPP} \text { or TC2 models }\end{array}$ & $\begin{array}{l}\text { No requirements regarding user data } \\
\text { rate (1kbps) or latency }\end{array}$ & $\begin{array}{l}\text { Connections: } 3 \times 10^{5} \text { per cell } \\
\text { Traffic: up to } 300 \mathrm{Mbps} \text { per cell }\end{array}$ & $\begin{array}{l}125 \text { bytes transmitted every } 5 \\
\text { minutes }\end{array}$ \\
\hline $\begin{array}{l}\text { TC12 } \\
\text { Traffic } \\
\text { efficiency } \\
\text { and safety }\end{array}$ & $\begin{array}{lr}\text { Automotive } & \\
\text { safety rervices } \\
\text { with reliability, } \\
\text { availability } \quad \text { and } \\
\text { latency requirements }\end{array}$ & $\begin{array}{l}\text { Environment: any road environment, } \\
\text { whether this is urban, rural or highway } \\
\text { Deployment: all vehicles equipped with the } \\
\text { METIS system and some road infrastructure } \\
\text { equipped with communication modules }\end{array}$ & $\begin{array}{l}\text { Data rate: } 100 \mathrm{kbps} \\
\text { Latency: }<5 \mathrm{~ms}\end{array}$ & $\begin{array}{l}\text { Connections: up to } 1000,100 \text { and } 100 \\
\text { users } / \mathrm{km}^{2} \text { for urban, rural or highway } \\
\text { environments, respectively } \\
\text { Traffic: } 0.01-0.1 \mathrm{Gbps} / \mathrm{km}^{2}\end{array}$ & $\begin{array}{l}\text { Periodic and event-driven } \\
\text { broadcast traffic ( } 1600 \text { bytes } \\
\text { with repetition rate from } 5 \text { to } \\
10 \mathrm{~Hz} \text { from local environment } \\
\text { perception and } 500 \text { bytes } \\
\text { for communication between } \\
\text { vehicles) }\end{array}$ \\
\hline
\end{tabular}


considered, which are summarized in Table XVIII: 50 Mbps everywhere, high speed train, sensor networks, tactile internet, automatic traffic control/driving, broadcast like services and dense urban society. Most of these scenarios employ macrocell deployments except tactile internet and dense urban society, which also use small cells.

3) mmMAGIC: Co-funded by the European Commission's 5G PPP program, the mmMAGIC project is focused on the research and development of novel radio access technologies at the millimeter-wave frequency bands (from 6 to $100 \mathrm{GHz}$ ). mmMAGIC [111] [112] presents the initial concepts envisioned for $5 \mathrm{G} \mathrm{mm}$-wave architecture, discussing some crucial aspects including use cases, deployments and requirements.

Test scenarios are grouped into outdoor, outdoor-to-indoor, and indoor. These scenarios have been derived from other projects like WINNER-I/II, METIS, and 3GPP recommendations. Outdoor scenarios include Madrid grid, Manhattan grid, Asian city grid and simplified Madrid grid. Indoor scenarios include virtual reality office, shopping mall, and stadium. For mixed indoor/outdoor scenarios, the dual-stripe scenario from 3GPP is proposed. [111] provides more details about these scenarios.

In mmMAGIC, few details are given about the traffic models for evaluating the different use cases. [111] only specifies that full buffer as well as finite buffer traffic models will be investigated for both 50+ Mbps everywhere and Cloud services use cases.

4) SPEED-5G: The Speed-5G project [102] aims to achieve a better exploitation of heterogeneous wireless technologies, supporting ultra-densification and the new QoE 5G requirements.

Deliverable D3.2 [113] contains a detailed description of the use cases for this project. The main scenarios investigated in SPEED-5G refer to indoor and indoor/outdoor scenarios where capacity demands are the highest: Massive IoT communications (mIoT), enhanced Mobile Broadband (eMBB), UltraReliable Communications (URC), and High-Speed Mobility.

According to [114], the main sources of scenarios for $5 \mathrm{G}$ system level simulations in this project are 3GPP, NGMN and METIS. No new traffic models are defined in the deliverable documents of this project, since only 3GPP FTP traffic model 2, VoIP, and H264 video traffic (using real traces) are used [115].

5) 5G-NORMA: This project [116] aims to develop a conceptually novel, adaptive and future-proof $5 \mathrm{G}$ mobile network architecture. For that purpose, it relies on NFV (Network Functions Virtualization) and SDN (Software Defined Networking) paradigms, as well as the usage of network slicing [117].

Deliverable 2.1 [118] includes the following use cases, which has been built on those developed by NGMN, METIS and 3GPP: industry control, enhanced mobile broadband, emergency communications, vehicle communications, sensor networks monitoring, traffic jam, real-time remote computing, massive nomadic mobile machine type communications, quality-aware communications, fixed-mobile convergence, blind spots, and open air festival.

The requirements from these use cases can be grouped around three main axes: very low latency and reliability
Table XVII: Summary of METIS traffic models [105]

\begin{tabular}{|c|c|c|}
\hline Traffic type & $\begin{array}{l}\text { Burst size / } \\
\text { Packet size }\end{array}$ & $\begin{array}{l}\text { Reading time / } \\
\text { Inter packet delay }\end{array}$ \\
\hline \multicolumn{3}{|c|}{ Based on 3GPP FTP Model 2 [53] } \\
\hline $\begin{array}{l}\text { Bursty User-Driven } \\
(B U D) \text { traffic }\end{array}$ & 20 Mbytes & $\begin{array}{l}\text { Derived from traffic } \\
\text { volume }\end{array}$ \\
\hline $\begin{array}{l}\text { Non Real-Time Video } \\
\text { Traffic }(N R T \text { VT) }\end{array}$ & $\begin{array}{lcr}\begin{array}{l}\text { Derived } \\
\text { coding }\end{array} & \text { rate } & \text { target } \\
\text { 50Mbps) } & & \end{array}$ & $1 \mathrm{~s}$ \\
\hline $\begin{array}{l}\text { Bursty Application- } \\
\text { Driven }(B A D) \text { traffic }\end{array}$ & 2 Mbytes & $\begin{array}{l}\text { Derived from traffic } \\
\text { volume }\end{array}$ \\
\hline \multicolumn{3}{|c|}{ Real time streaming } \\
\hline $\begin{array}{l}\text { Real-Time Video Traf- } \\
\text { fic }(R T V T)\end{array}$ & $\begin{array}{l}\text { Uniformly distributed } \\
\text { between } 3 \text { and } 6 \text { kbytes }\end{array}$ & $36 \mathrm{~ms}$ \\
\hline \multicolumn{3}{|c|}{ Moving networks } \\
\hline $\begin{array}{l}\text { Vehicle to Infrastruc- } \\
\text { ture (V2I) traffic }\end{array}$ & 20 Mbytes & $\begin{array}{l}\text { Derived from traffic } \\
\text { volume }\end{array}$ \\
\hline $\begin{array}{l}\text { Vehicle to Vehicle } \\
(V 2 V) \text { traffic }\end{array}$ & 1.6 kbytes & $100 \mathrm{~ms}$ \\
\hline \multicolumn{3}{|c|}{ Massive Machine Communication (MMC) } \\
\hline $\begin{array}{l}\text { BAD RT streaming } \\
1 \mathrm{Mbps}\end{array}$ & 125 kbytes & $1 \mathrm{~s}$ \\
\hline$B A D N R T$ & 2 Mbytes & $\begin{array}{l}\text { Derived from traffic } \\
\text { volume }\end{array}$ \\
\hline$B A D N R T$ for $T C 11$ & 125 bytes & $300 \mathrm{~s}$ \\
\hline \multicolumn{3}{|c|}{ Direct D2D communication } \\
\hline BUD traffic & 20 Mbytes & $\begin{array}{l}\text { Derived from traffic } \\
\text { volume }\end{array}$ \\
\hline VoIP WB AMR & 69 bytes & $20 \mathrm{~ms}$ \\
\hline
\end{tabular}

for critical machine type communications; high throughput for massive broadband communications and the ability to support high volumes of devices for massive machine type of communications.

To validate the proposed architectural solutions, 5G NORMA defines two scenario frameworks comprising the previous use cases:

- Multi-service scenario framework: focused on multiservice and context-aware adaptation of network functions. It comprises the following use cases: enhanced mobile broadband, vehicle communications, emergency communications, traffic jams, real-time remote computing, quality-aware communications, blind spots, and open air festival.

- Multi-tenant scenario framework: based on the idea of sharing the same infrastructure among different tenants (participant operators, vertical market players, etc.), transparent to end users. It comprises the following use cases: industry control, vehicular communications, sensor network monitoring, traffic jam, and open air festival.

Table XIX presents the performance requirements for the aforementioned use cases according to 5G-NORMA. We refer the reader to [118] for more information about these use cases, such as a complete description, functional requirements and relevant KPIs.

In this case, no details are given about traffic models, although deliverable D2.3 [120] includes data volumes for some of the aforementioned use cases.

\section{G. NGMN}

The NGMN Alliance (Next Generation Mobile Network Alliance) is an open forum composed of mobile network 
Table XVIII: Summary of FANTASTIC-5G use cases

\begin{tabular}{|c|c|c|}
\hline Use case & Scenario & Traffic pattern \\
\hline $\begin{array}{l}50 \quad \text { Mbps } \\
\text { every- } \\
\text { where }\end{array}$ & $\begin{array}{l}19 \text { macro base stations with } \\
\text { ISD of } 250 \mathrm{~m} \text { (suburban) or } \\
500 \mathrm{~m} \text { (rural) in a hexagonal } \\
\text { grid [51]; } 400 \text { users } / \mathrm{km}^{2} \text { (sub- } \\
\text { urban) or } 100 \text { users } / \mathrm{km}^{2} \text { (ru- } \\
\text { ral), } 80 \% \text { UEs indoor, } 20 \% \\
\text { UEs outdoor }\end{array}$ & $\begin{array}{l}\text { Infinite buffer or } 3 \mathrm{GPP} \\
\text { FTP Model } 2 \text { [54] }\end{array}$ \\
\hline $\begin{array}{l}\text { High } \\
\text { speed train }\end{array}$ & $\begin{array}{l}\text { Hexagonal grid with macro } \\
\text { BTSs (ISD } 1732 \mathrm{~m} \text { ) in the cor- } \\
\text { ner of the cell [51]; } 2000 \\
\text { users } / \mathrm{km}^{2} \text { (in a straight line) }\end{array}$ & $\begin{array}{l}\text { Mix of V2I (UL) and } \\
\text { I2V (DL). I2V modeled } \\
\text { as 3GPP FTP Model } 2 \\
\text { [54] and V2I modeled } \\
\text { as CBR sources [105]. }\end{array}$ \\
\hline $\begin{array}{l}\text { Sensor } \\
\text { networks }\end{array}$ & $\begin{array}{l}\text { Macro cells (hexagonal grid } \\
\text { with BTSs in the corner of the } \\
\text { cell [51]), Small cells with ran- } \\
\text { dom deployment [119]; thou- } \\
\text { sands of households (13 de- } \\
\text { vices } / \text { household) [57] and } 500 \\
\text { cars } / \mathrm{km}^{2} \text { ( } 6 \text { devices/car) }\end{array}$ & $\begin{array}{l}\text { "Regular reporting" and } \\
\text { "triggered reporting" } \\
\text { from [57], generation } \\
\text { throughout time based } \\
\text { on Model } 1 \text { (uniform } \\
\text { distribution) and Model } \\
2 \text { (beta distribution) } \\
\text { from [56]. }\end{array}$ \\
\hline $\begin{array}{l}\text { Tactile In- } \\
\text { ternet }\end{array}$ & $\begin{array}{l}\text { Hexagonal grid with BTSs } \\
\text { in the corner of the cell } \\
\text { [51]. Macro cells for urban } \\
\text { (ISD 500m) or suburban (ISD } \\
\text { 1732m), small cells for ur- } \\
\text { ban (ISD 50m); up to } 20,000 \\
\text { users } / \mathrm{km}^{2}\end{array}$ & As for use case 1 \\
\hline $\begin{array}{l}\text { Automatic } \\
\text { traffic } \\
\text { control / } \\
\text { driving }\end{array}$ & $\begin{array}{l}\text { Macro BTSs with ISD } 1732 \mathrm{~m} \\
\text { (suburban) or } 4330 \mathrm{~m} \text { (rural); } \\
1000 \text { (rural), } 2000 \text { (suburban) } \\
\text { or } 3000 \text { (urban) devices } / \mathrm{km}^{2}\end{array}$ & $\begin{array}{l}\text { Mix of V2I (BUD traf- } \\
\text { fic [105] and V2V (mes- } \\
\text { sages of 190,300, } 800 \\
\text { bytes) [106] }\end{array}$ \\
\hline $\begin{array}{l}\text { Broadcast } \\
\text { like } \\
\text { services: } \\
\text { local, } \\
\text { regional, } \\
\text { national }\end{array}$ & $\begin{array}{l}\text { Macro BTSs and user distribu- } \\
\text { tion as for use case } 1\end{array}$ & $\begin{array}{l}\text { Real time streaming (17 } \\
\text { Mbps for } 4 \mathrm{~K} \text { UHDTV } \\
\text { using real traces) and } \\
\text { non-real time applica- } \\
\text { tions }(1 / 3 \text { of the rate for } \\
\text { use case } 1)\end{array}$ \\
\hline $\begin{array}{ll}\text { Dense } & \\
\text { urban } & \\
\text { society } \\
\text { below } 6 \\
\text { GHz }\end{array}$ & $\begin{array}{l}\text { Macro cells (ISD 500m) and } \\
\text { small cells (ISD 50m); up to } \\
2500 \text { users } / \mathrm{km}^{2}\end{array}$ & As for use case 1 \\
\hline
\end{tabular}

operators (members), vendors/manufacturers (sponsors) and universities or non-industrial research institutes (advisors). Its goal is to ensure that the standards for next-generation mobile networks will meet the requirements of operators and, ultimately, will satisfy end user demand and expectations.

The 5G vision of the NGMN Alliance [121] defines 5G as "an end-to-end ecosystem to enable a fully mobile and connected society". 5G will be able to be available anywhereanytime, be delivered with consistent experience, be accessible on multiple devices / interfaces, support multiple interaction types, be supported transparently across technologies, be delivered in a personalized and contextual fashion, be enabled by trusted \& reliable communications, be highly reliable and resilient network, and support responsive and real-time communications. In that sense, it will provide higher data rates and lower latencies for consumers, providing differentiated capabilities depending on enterprise application needs, and the required flexibility for verticals to operate their own applications in a profitable manner.

For these purposes, NGMN [122] envisions a 5G system architecture comprising three layers: the infrastructure layer (physical resources exposed to higher layers), the business
Table XIX: Performance requirements of 5G-NORMA use cases

\begin{tabular}{llr}
\hline $\begin{array}{l}\text { Use } \\
\text { case }\end{array}$ & \multicolumn{2}{l}{ Description } \\
\hline $\begin{array}{l}\text { Industry } \\
\text { control }\end{array}$ & $\begin{array}{l}\text { Industrial } \\
\text { monitoring } \\
\text { control services }\end{array}$ & $\begin{array}{r}\text { process } \\
\text { and }\end{array}$ \\
& & \\
& & \\
& & \\
\hline Enhanced & User can ubiquitously \\
Mobile & connect & with \\
Broad- & extremely & high \\
band & data rates &
\end{tabular}

Requirements

Very low latency (less than $1 \mathrm{~ms}$ ), tens of Mbps per device in dense environment, high reliability (error rates lower than $10^{-9}$ ), seamless connection re-establishment, large user densities, highly accurate position information (from $1 \mathrm{~m}$ to $1 \mathrm{~cm}$ )

with 10 s of Gbps), low latency (e. . 10s outdoors of Tbps $/ \mathrm{km}^{2}$ ), high mobility (e.g. $500 \mathrm{~km} / \mathrm{h}$ with $10 \mathrm{Mbps}$ and $10 \mathrm{~ms}$ )

\begin{tabular}{llllrr}
\hline Emergency Part of the network & Network & connectivity & re- \\
com- & is destroyed due to & establishment & in less than & 60 \\
munica- & a natural disaster & s. Support & more than & 1000 \\
tions & (e.g. earthquake, & simultaneous & connections & per \\
& tsunamis, floods, and & cell and MHz. & & & \\
& & & &
\end{tabular}
hurricanes)

Vehicular Real-time Latency for critical messages related
com- information about to safety lower than $5 \mathrm{~ms}$, high nummunica- road and traffic ber of active connections (1500-2500 tions conditions for traffic vehicles expected per lane) safety and driving assistance

Sensor Monitoring a wide $100 \%$ geographic coverage, support network area for a particular unsolicited information from sensor monitor- measured property devices, highly reliable communicaing tion and prioritization (but not stringent latency restrictions)

Traffic Public cloud services Voice with 21-320 Kbps and $<150$ jam (e.g. video, web ms, video with $100 \mathrm{Mbps}$ DL and 20 browsing, file Mbps UL and $<300 \mathrm{~ms}$, public cloud downloading) for services with $100 \mathrm{Mbps}$ DL and 20 users inside vehicles Mbps with $<100 \mathrm{~ms}, 1000$ attach during traffic jams attempts/second

Real- Variety of future Latencies between 100 and $170 \mathrm{~ms}$
time applications such as for RT voice and video communicaremote cloud computing, tions, $<10 \mathrm{~ms}$ for remote execution comput- remote gaming, of application, augmented reality, viring remote device tual office, tactile, and remotely concontrol, tactile trolled vehicles; $100 \mathrm{Mbps} \mathrm{DL}$ and internet, etc. $20 \mathrm{Mbps}$ UL; high speed $(350 \mathrm{~km} / \mathrm{h})$; availability $99 \%$; reliability $95 \%$

\begin{tabular}{|c|c|c|}
\hline $\begin{array}{l}\text { Massive } \\
\text { no- } \\
\text { madic/ } \\
\text { mobile } \\
\text { MTC }\end{array}$ & $\begin{array}{l}\text { For sensors or } \\
\text { actuators physically } \\
\text { mounted on nomadic } \\
\text { and mobile objects }\end{array}$ & $\begin{array}{l}\text { Small data payloads ( } 20-125 \text { bytes) } \\
\text { with moderate latency requirements } \\
(\sim 1 \mathrm{~s}) \text {; high speed }(500 \mathrm{Km} / \mathrm{h}) \text {; long } \\
\text { battery lifetime (up to } 15 \text { years) and } \\
\text { low cost; high density (up to } 200.000 \\
\text { active sensor connections per } \mathrm{km}^{2}\end{array}$ \\
\hline $\begin{array}{l}\text { Quality- } \\
\text { aware } \\
\text { com- } \\
\text { munica- } \\
\text { tions }\end{array}$ & $\begin{array}{l}\text { Network reacts to the } \\
\text { quality of the services } \\
\text { provided to the users } \\
\text { (both QoS and QoE) }\end{array}$ & $\begin{array}{l}\text { Support changing conditions (e.g. } \\
\text { mobility) and highly scalable to han- } \\
\text { dle a high number of users simulta- } \\
\text { neously }\end{array}$ \\
\hline $\begin{array}{l}\text { Fixed- } \\
\text { Mobile } \\
\text { Conver- } \\
\text { gence } \\
\text { (FMC) }\end{array}$ & $\begin{array}{l}\text { Seamless customer } \\
\text { experience within } \\
\text { the fixed and } \\
\text { mobile domains, } \\
\text { independently of his } \\
\text { access type }\end{array}$ & $\begin{array}{l}\text { Fast and seamless handover between } \\
\text { wireless technologies as well as be- } \\
\text { tween mobile and fixed access do- } \\
\text { mains }\end{array}$ \\
\hline $\begin{array}{l}\text { Blind } \\
\text { spots }\end{array}$ & $\begin{array}{l}\text { High QoE in blind } \\
\text { spots }\end{array}$ & $\begin{array}{l}100 \text { Mbps DL and } 20 \text { Mbps UL, } \\
\text { latency }<100 \mathrm{~ms} \text {, availability } 95 \% \text {, } \\
\text { reliability } 95 \%\end{array}$ \\
\hline $\begin{array}{l}\text { Open } \\
\text { Air } \\
\text { Festival }\end{array}$ & $\begin{array}{l}\text { Remote and rural area } \\
\text { with tens of thou- } \\
\text { sands of a visitors for } \\
\text { a multi-day open air } \\
\text { music festival }\end{array}$ & $\begin{array}{l}\text { Data rate } 30 \text { Mbps per user, }<1 \mathrm{~s} \\
\text { for machine/devices, delivery of de- } \\
\text { lay tolerant data in less than } 10 \mathrm{~min} \\
\text { with } 95 \% \text { probability, availability for } \\
\text { users } 95 \% \text {, availability for sensors } \\
100 \%\end{array}$ \\
\hline
\end{tabular}


Table XX: Summary of NGMN use cases

\begin{tabular}{|c|c|c|c|c|}
\hline Family & Category & Use case & User requirements & System requirements \\
\hline \multirow{3}{*}{$\begin{array}{l}\text { Broadband access in } \\
\text { dense area }\end{array}$} & $\begin{array}{l}\text { Broadband access in } \\
\text { dense area }\end{array}$ & $\begin{array}{l}\text { Pervasive video } \\
\text { Operator cloud services } \\
\text { Dense urban society }\end{array}$ & $\begin{array}{l}\text { Data rate: } 300(50) \mathrm{Mbps} \mathrm{DL}(\mathrm{UL}) \\
\text { E2E latency: } 10 \mathrm{~ms}\end{array}$ & $\begin{array}{l}\text { Connections: } 200-2500 / \mathrm{km}^{2} \\
\text { Traffic: } 750(125) \mathrm{Gbps} / \mathrm{km}^{2} \mathrm{DL}(\mathrm{UL})\end{array}$ \\
\hline & $\begin{array}{l}\text { Indoor ultra-high } \\
\text { broadband access }\end{array}$ & Smart office & $\begin{array}{l}\text { Data rate: } 1000(500) \mathrm{Mbps} \text { DL(UL) } \\
\text { E2E latency: } 10 \mathrm{~ms}\end{array}$ & $\begin{array}{l}\text { Connections: } 75000 / \mathrm{km}^{2} \\
\text { Traffic: } 15(2) \mathrm{Tbps} / \mathrm{km}^{2} \text { DL(UL) }\end{array}$ \\
\hline & $\begin{array}{l}\text { Broadband access in } \\
\text { a crowd }\end{array}$ & $\begin{array}{l}\text { HD video/photo sharing in } \\
\text { stadium/open-air gathering }\end{array}$ & $\begin{array}{l}\text { Data rate: } 25(50) \mathrm{Mbps} \text { DL(UL) } \\
\text { E2E latency: } 10 \mathrm{~ms}\end{array}$ & $\begin{array}{l}\text { Connections: } 150000 / \mathrm{km}^{2} \\
\text { Traffic: } 3.75(7.5) \mathrm{Tbps} / \mathrm{km}^{2} \mathrm{DL}(\mathrm{UL})\end{array}$ \\
\hline \multirow[t]{2}{*}{$\begin{array}{l}\text { Broadband access } \\
\text { everywhere }\end{array}$} & $\begin{array}{l}\text { 50+ Mbps } \\
\text { everywhere }\end{array}$ & 50 Mbps everywhere & $\begin{array}{l}\text { Data rate: } 50(25) \mathrm{Mbps} \mathrm{DL}(\mathrm{UL}) \\
\text { E2E latency: } 10 \mathrm{~ms}\end{array}$ & $\begin{array}{l}\text { Connections: } 400 / \mathrm{km}^{2} \text { in suburban, } 100 / \mathrm{km}^{2} \text { in } \\
\text { rural } \\
\text { Traffic: } 20(10) \mathrm{Gbps} / \mathrm{km}^{2} \mathrm{DL}(\mathrm{UL}) \text { in suburban, } \\
5(2.5) \mathrm{Gbps} / \mathrm{km}^{2} \mathrm{DL}(\mathrm{UL}) \text { in rural }\end{array}$ \\
\hline & $\begin{array}{l}\text { Ultra low-cost } \\
\text { broadband access for } \\
\text { low ARPU areas }\end{array}$ & Ultra-low cost networks & $\begin{array}{l}\text { Data rate: } 10(10) \mathrm{Mbps} \mathrm{DL}(\mathrm{UL}) \\
\text { E2E latency: } 50 \mathrm{~ms}\end{array}$ & $\begin{array}{l}\text { Connections: } 16 / \mathrm{km}^{2} \\
\text { Traffic: } 16 \mathrm{Mbps} / \mathrm{km}^{2}\end{array}$ \\
\hline \multirow[t]{2}{*}{ High user mobility } & $\begin{array}{l}\text { Mobile broadband in } \\
\text { vehicles }\end{array}$ & $\begin{array}{l}\text { High speed train } \\
\text { Moving hot spots } \\
\text { Remote computing }\end{array}$ & $\begin{array}{l}\text { Data rate: } 50(25) \mathrm{Mbps} \text { DL(UL) } \\
\text { E2E latency: } 10 \mathrm{~ms}\end{array}$ & $\begin{array}{l}\text { Connections: } 2000 / \mathrm{km}^{2} \\
\text { Traffic: } 25(12.5) \mathrm{Gbps} / \mathrm{train} \mathrm{DL}(\mathrm{UL}) \text {, } \\
\text { 50(25)Mbps/car DL(UL) }\end{array}$ \\
\hline & $\begin{array}{l}\text { Airplanes } \\
\text { connectivity }\end{array}$ & 3D connectivity: aircrafts & $\begin{array}{l}\text { Data rate: } 15(7.5) \mathrm{Mbps} \text { DL(UL) } \\
\text { E2E latency: } 10 \mathrm{~ms}\end{array}$ & $\begin{array}{l}\text { Connections: } 80 / \mathrm{plane} \\
\text { Traffic: } 1.2(0.6) \mathrm{Gbps} / \mathrm{plane}\end{array}$ \\
\hline \multirow[t]{2}{*}{$\begin{array}{l}\text { Massive Internet of } \\
\text { Things }\end{array}$} & $\begin{array}{l}\text { Massive } \\
\text { low-cost/long- } \\
\text { range/low-power } \\
\text { MTC }\end{array}$ & $\begin{array}{l}\text { Smart wearables (clothes) } \\
\text { Sensor networks }\end{array}$ & $\begin{array}{l}\text { Data rate: low (typically } 1-100 \mathrm{kbps}) \\
\text { E2E latency: seconds to hours }\end{array}$ & $\begin{array}{l}\text { Connections: } 200000 / \mathrm{km}^{2} \\
\text { Traffic: not critical }\end{array}$ \\
\hline & Broadband MTC & Mobile video surveillance & \multicolumn{2}{|c|}{ Same as Broadband access in dense areas and $50+$ Mbps everywhere categories } \\
\hline $\begin{array}{l}\text { Extreme real time } \\
\text { communication }\end{array}$ & Ultra low latency & Tactile internet & $\begin{array}{l}\text { Data rate: } 50(25) \mathrm{Mbps} \mathrm{DL}(\mathrm{UL}) \\
\text { E2E latency: }<1 \mathrm{~ms}\end{array}$ & $\begin{array}{l}\text { Connections: not critical } \\
\text { Traffic: potentially high }\end{array}$ \\
\hline $\begin{array}{l}\text { Lifeline } \\
\text { communication }\end{array}$ & $\begin{array}{l}\text { Resilience and traffic } \\
\text { surge }\end{array}$ & Natural disaster & $\begin{array}{l}\text { Data rate: } 0.1-1 \mathrm{Mbps} \text { DL and UL } \\
\text { E2E latency: not critical }\end{array}$ & $\begin{array}{l}\text { Connections: } 10000 / \mathrm{km}^{2} \\
\text { Traffic: potentially high }\end{array}$ \\
\hline \multirow[t]{2}{*}{$\begin{array}{l}\text { Ultra-reliable } \\
\text { communication }\end{array}$} & $\begin{array}{l}\text { Ultra-high reliability } \\
\& \text { ultra low latency }\end{array}$ & $\begin{array}{l}\text { Automatic traffic control/driving } \\
\text { Collaborative robots } \\
\text { Remote object manipulation - remote } \\
\text { surgery }\end{array}$ & $\begin{array}{l}\text { Data rate: from } 50 \mathrm{kbps} \text { to } 10 \mathrm{Mbps} \text { (from a } \\
\text { few bps to } 10 \mathrm{Mbps}) \mathrm{DL}(\mathrm{UL}) \\
\text { E2E latency: } 1 \mathrm{~ms}\end{array}$ & $\begin{array}{l}\text { Connections: not critical } \\
\text { Traffic: potentially high }\end{array}$ \\
\hline & $\begin{array}{l}\text { Ultra-high } \\
\text { availability and } \\
\text { reliability }\end{array}$ & $\begin{array}{l}\text { e-Health: extreme life critical } \\
\text { Public safety } \\
\text { 3D connectivity: drones }\end{array}$ & $\begin{array}{l}\text { Data rate: } 10(10) \mathrm{Mbps} \mathrm{DL}(\mathrm{UL}) \\
\text { E2E latency: } 10 \mathrm{~ms}\end{array}$ & $\begin{array}{l}\text { Connections: not critical } \\
\text { Traffic: potentially high }\end{array}$ \\
\hline $\begin{array}{l}\text { Broadcast like } \\
\text { services }\end{array}$ & $\begin{array}{l}\text { Broadcast like } \\
\text { services }\end{array}$ & $\begin{array}{l}\text { News and information } \\
\text { Broadcast like services: local, } \\
\text { regional, national }\end{array}$ & $\begin{array}{l}\text { Data rate: Up to 200Mbps (modest, e.g. } \\
500 \mathrm{kbps}) \mathrm{DL}(\mathrm{UL}) \\
\text { E2E latency: }<100 \mathrm{~ms}\end{array}$ & $\begin{array}{l}\text { Connections: not relevant } \\
\text { Traffic: not relevant }\end{array}$ \\
\hline
\end{tabular}


enablement layer (library of all functions in the form of modular building blocks), and the business application layer (specific applications and services of the operator, enterprise, verticals, or other third parties).

NGMN has developed twenty five use cases for 5G [123] (summarized in Table XX), as representative examples, that are grouped into fourteen categories and into eight families. The specified families are: broadband access in dense area, broadband access everywhere, high user mobility, massive Internet of Things, extreme real time communication, lifeline communication, ultra-reliable communication and broadcast like services. For each use case category, the main requirements in terms of user experience and system performance are specified.

No traffic patterns are specified in [123] but only brief descriptions of the expected services, e.g. watch high definition playback video, share live video or post HD photos to social networks in the use case $H D$ video/photo sharing in stadium/open-air gathering.

NGMN also describes how to test the performance of individual features (such as massive MIMO, beamforming for eMBB, waveforms, etcetera) in [124]. However, only few and simplistic traffic models were included: Poisson distributed packet arrivals, full buffer, FTP traffic model 3, and FTP traffic model 1.

Similarly, in [125] NGMN describes the testing framework for the NMGN 5G pre-commercial network trials. Five scenarios are considered for eMBB and URLLC, out of the twelve defined in [51] for eMBB, URLLC, mMTC and eV2X (enhanced Vehicle to Everything). Only full buffer or real traffic (e.g. using traffic generators, the iperf tool, or real applications) are considered.

Additionally, NGMN presents in [126] the simulation assumptions and results for their liaison to 5GAA (5G Automotive Association) in order to compare LTE-V2X (also known as C-V2X, Cellular Vehicle to Everything) to DSRC (Dedicated Short Range Communications). The scenarios cover both NLOS and LOS with vehicle speeds from 15 to $250 \mathrm{~km} / \mathrm{h}$, with two use cases for urban (with 2 lanes for each direction) and freeway (with 3 lanes for each direction). The traffic model for V2V (vehicle to vehicle) includes periodic and eventtriggered traffic cases. For periodic traffic, it is assumed that one application layer message of 300 bytes is followed by four messages of 190 bytes. The first message is randomized among vehicles. For event-triggered traffic, the event arrival follows a Poisson process with an arrival rate to be defined. Once the event is triggered, 6 messages of 800 bytes are generated (separated $100 \mathrm{~ms})$. The link layer overhead is 16 bytes for C-V2X (MAC (10 bytes) / RLC ( 1 byte) / PDCP (5 bytes)) and 38 bytes for DSRC (MAC (30 bytes) / LLC ( 8 bytes)).

In the case of 4G, NGMN [89] proposed a complete evaluation methodology for the requirements for IMT-Advanced (LTE and WiMAX), defining a set of common evaluation scenarios. These traffic models match those defined by 3GPP (see Table V).

\section{DISCUSSION}

As it is noticed, there are many different use cases depending on the particular objective(s) of the organization or research project. This is legitimate since each technology, scenario, environment, type of device, type of service, etcetera, has its own particularities that must be considered for a realistic and fair performance evaluation.

However, in many cases some general test scenarios could be enough to assess a specific solution. In this sense, we believe that the IMT-2020 test environments presented in Table I could be utilized. These test cases are also found, with minor differences, in the proposals from the organizations and projects analyzed in this survey. Table XXI presents a mapping between these use cases. For example, most of the organizations define test scenarios for indoor isolated environments such as offices and shopping malls, which can be mapped to the ITU's indoor hotspot scenario. Urban environments with high user density and traffic loads are contemplated as well, which can be mapped to the ITU's dense urban case. And similarly for the other cases (rural environment, and mMTC and URLLC services).

Since the objective of the research and proposals for $5 \mathrm{G}$ is the fulfillment of IMT-2020 requirements, we propose to utilize the five IMT-2020 test environments (indoor hotspot-eMBB, dense urban-eMBB, rural-eMBB, urban macro-mMTC, and urban macro-URLLC) as the general use cases for $5 \mathrm{G}$ performance evaluation. Report ITU-R M.2412 [4] defines all the details such as the scenario, power values, frequency range, base station deployment, mobility, user/device density, traffic load, propagation models, among many others.

However, in these test environments invariably the traffic is generated assuming a full buffer model. Since this traffic model is clearly unrealistic, which may impact on the performance evaluation [127], we propose to utilize the traffic mixes shown in Table XXII based on the METIS project. Additionally, due to its importance from the enduser experience point of view, we believe that voice should be included. Although voice only represents $2 \%$ [60] of the total traffic, its performance should be assessed in the general use cases in order to have a complete vision of the end-user's experience.

The METIS traffic models (summarized in Table XVII) have also some drawbacks from end-users perspective, since the time between packets or sessions is derived from the traffic volume. This assumption is not realistic, because the traffic generated by one user should not be affected by the global traffic load. For that reason, we propose here the usage of other traffic models instead of those from METIS. Table XXII presents our proposal. As shown, dense urban information society (TC2) is recommended for the dense urban scenario; blind spots (TC7) represents the rural environment; massive deployment of sensors and actuators (TC11) defines the connection density for the urban macro-mMTC deployments; and traffic efficiency and safety (TC12) is employed as the URLLC service. Besides, since METIS TC1 (virtual reality office) only includes FTP-based models (like ITU and 3GPP), we propose 
Table XXI: Mapping of use cases from different sources to IMT-2020 use cases

\begin{tabular}{|c|c|c|c|c|c|c|}
\hline IMT-2020 & 3GPP & 5G PPP & METIS & FANTASTIC 5G & 5G-NORMA & NGMN \\
\hline $\begin{array}{l}\text { Indoor } \\
\text { hotspot- } \\
\text { eMBB }\end{array}$ & $\begin{array}{l}\text { Indoor } \\
\text { hotspot-eMBB }\end{array}$ & $\begin{array}{l}\text { Future smart } \\
\text { offices }\end{array}$ & $\begin{array}{l}\text { TC1 virtual } \\
\text { reality office }\end{array}$ & & & Smart office \\
\hline $\begin{array}{l}\text { Dense } \\
\text { urban-eMBB }\end{array}$ & Dense urban & $\begin{array}{l}\text { Broadband } \\
\text { access } \\
\text { everywhere }\end{array}$ & $\begin{array}{l}\text { TC2 dense urban } \\
\text { information } \\
\text { society }\end{array}$ & $\begin{array}{l}50 \mathrm{Mbps} \\
\text { everywhere } \\
\text { Dense urban society } \\
\text { below } 6 \mathrm{GHz}\end{array}$ & $\begin{array}{l}\text { Enhanced mobile } \\
\text { broadband }\end{array}$ & $\begin{array}{l}\text { Dense urban society } \\
50 \mathrm{Mbps} \text { everywhere }\end{array}$ \\
\hline Rural-eMBB & Rural & & TC7 blind spots & & Blind spots & Ultra-low cost networks \\
\hline $\begin{array}{l}\text { Urban } \\
\text { macro- } \\
\text { mMTC }\end{array}$ & $\begin{array}{l}\text { Urban } \\
\text { coverage for } \\
\text { massive } \\
\text { connection }\end{array}$ & mMTC & $\begin{array}{l}\text { TC11 massive } \\
\text { deployment of } \\
\text { sensors and } \\
\text { actuators }\end{array}$ & Sensor networks & $\begin{array}{l}\text { Massive } \\
\text { nomadic/mobile } \\
\text { MTC }\end{array}$ & Sensor networks \\
\hline $\begin{array}{l}\text { Urban } \\
\text { macro- } \\
\text { URLLC }\end{array}$ & $\begin{array}{l}\text { eMBB } \\
\text { deployment } \\
\text { scenarios may } \\
\text { be reused to } \\
\text { evaluate } \\
\text { URLLC }\end{array}$ & $\begin{array}{l}\text { Connected } \\
\text { vehicles } \\
\text { Tactile internet/ } \\
\text { automation }\end{array}$ & $\begin{array}{l}\text { TC12 traffic } \\
\text { efficiency and } \\
\text { safety }\end{array}$ & $\begin{array}{l}\text { Tactile internet } \\
\text { Automatic traffic } \\
\text { control/driving }\end{array}$ & $\begin{array}{l}\text { Industry control } \\
\text { Vehicular } \\
\text { communications }\end{array}$ & $\begin{array}{l}\text { 3D connectivity: aircrafts } \\
\text { Mobile video surveillance } \\
\text { Tactile internet } \\
\text { Automatic traffic control/ } \\
\text { driving } \\
\text { Collaborative robots } \\
\text { Remote object manipulation: } \\
\text { remote surgery } \\
\text { e-Health: extreme life critical } \\
\text { Public safety } \\
\text { 3D connectivity: drones }\end{array}$ \\
\hline
\end{tabular}

Table XXII: Proposal for 5G performance evaluation

\begin{tabular}{ll}
\hline IMT-2020 use case & Traffic pattern \\
\hline Indoor hotspot-eMBB & $\begin{array}{l}\text { Traffic mix defined for METIS TC2 }+2 \% \\
\text { of voice traffic, with traffic density from } \\
\text { METIS TC1 }\left(0.1 \mathrm{UEs} / \mathrm{m}^{2}\right)\end{array}$ \\
\hline Dense urban-eMBB & Traffic mix defined for METIS TC2 (see \\
& Table XVI) $+2 \%$ of voice traffic: $39 \%$ BUD \\
& traffic $(6 \%$ UL, 34\%DL), 39\% NRT VT (6\% \\
& UL, 34\% DL), 7.5\% BAD traffic (1.5\% UL, \\
& $6 \%$ DL), 7.5\% RT VT (1.5\% UL, 6\% DL), \\
& $5 \%$ traffic generated by sensors, $2 \%$ voice \\
& traffic \\
\hline Rural-eMBB & Traffic mix defined for METIS TC7 (same \\
& as TC2, see Table XVI) + 2\% of voice traffic \\
\hline Urban macro-mMTC & Traffic mix defined for METIS TC11: $3 \times$ \\
& $10^{5}$ devices per cell \\
\hline Urban macro-URLLC & Traffic mix defined for METIS TC12 for \\
& urban environment: up to 1000 users $/ \mathrm{km}^{2}$ \\
\hline
\end{tabular}

to utilize the traffic mix from METIS TC2 but assuming the connection density from TC1.

For realistic performance assessment, we suggest to use the traffic models included in Table XXIII. Starting with the bursty-user driven traffic, we propose to employ the web browsing service. Although we have already analyzed some web browsing models in this paper, they are obsolete (from 2008 or older). Fortunately, the literature that analyzes the traffic patterns produced by this service is abundant, e.g. [128][129][130][131][132]. Due to the detailed analysis performed, we have selected the model from [132]. In this work, the average web page size is defined by a uniform distribution between 60 and $1500 \mathrm{~KB}$.

Following with non-real time video, YouTube recommends to encode videos with $4 \mathrm{k}$ resolution for uploading to their platform using 35-45 Mbps for standard frame rate (24, 25, 30 fps) and 53-68 Mbps for high frame rate (48, 50, $60 \mathrm{fps})$ [133]. These values are in line with those proposed by METIS (50 Mbps, see Table XVII) and NGMN (25(50) Mbps UL(DL), see Table XX). Thus, we recommend an encoding rate of 50
Table XXIII: Proposed traffic models

\begin{tabular}{ll}
\hline Name & Traffic model \\
\hline BUD traffic & $\begin{array}{l}\text { Web traffic model from [132], i.e. web page } \\
\text { size with uniform distribution between 60 } \\
\text { and 1500 KB }\end{array}$ \\
\hline NRT VT & Video encoded with 50 Mbps and 30 fps \\
\hline BAD traffic & $\begin{array}{l}\text { 3GPP MTC traffic models 1 and 2 defined } \\
\text { in Table VI }\end{array}$ \\
\hline RT VT & CBR source with 1.5 Mbps \\
\hline Voice traffic & EVS-WB with 24.4 kbps, call duration with \\
& $\begin{array}{l}\text { log-normal distribution and average 202 } \\
\text { seconds, VAF }=50 \%\end{array}$ \\
\hline
\end{tabular}

Mbps with a frame rate of $30 \mathrm{fps}$.

For mMTC we select 3GPP traffic models 1 and 2 defined in Table VI. The first model is suitable for MTC devices accessing the network uniformly over a period of time, i.e. in a non-synchronized manner. The second model is appropriate for an extreme scenario in which a large amount of MTC devices access the network in a highly synchronized manner, e.g. after a power outage.

In the case of real-time video, we choose a CBR source with 1.5 Mbps, which is the Skype recommendation [134] for HD video calling. This data rate is in line with that of METIS, which demands a maximum of 1.37 Mbps (required data rate $=\frac{\text { max. packet size }}{\text { inter packet delay }}=\frac{6 \mathrm{Kbytes}}{36 \mathrm{~ms}}=1.37 \mathrm{Mbps}$, see Table XVII).

For voice traffic, we assume the EVS-WB codec at 24.4 kbps following a Log-normal distributed call duration with an average of 202 seconds (value suitable for residential environments [135]). For the voice activity factor, we select $50 \%$ like 3GPP and many works in the literature.

Finally, we would like to express that the guidelines provided in this survey may be useful for the performance assessment of many solutions, which may be more specific. In this regard, we believe that the scenarios and traffic models (and, in general, the performance evaluation guidelines) from 3GPP and the METIS project are very relevant, detailed and 
complete. Similarly, the use cases from NMGN are also very interesting, and we hope that they will provide in the future performance evaluation guidelines for $5 \mathrm{G}$ similar to those provided for $4 \mathrm{G}$ [89].

\section{OPEN RESEARCH ISSUES}

In this section, we identify usage scenarios and services that are foreseen for future mobile communication systems. We consider their definition and the elaboration of the required traffic models as open issues that shall be studied to facilitate further research on these new technologies.

These new applications will demand requirements several orders of magnitude higher than those of 5G. As an example, we include next the speculated requirements for IMT-2030 [136]:

- A peak data rate of at least $1 \mathrm{~Tb} / \mathrm{s}$, i.e. 100 times that of $5 \mathrm{G}$.

- A user-experienced data rate of $1 \mathrm{~Gb} / \mathrm{s}$, i.e. 10 times that of $5 \mathrm{G}$ (up to $10 \mathrm{~Gb} / \mathrm{s}$ in particular).

- Very low over-the-air latency $(10-100 \mu \mathrm{s})$ and high mobility ( $\geq 1,000 \mathrm{~km} / \mathrm{h}$ for e.g. hyper-high-speed railway and airline systems).

- Connectivity density of up to $10^{7}$ devices $/ \mathrm{km}^{2}$, i.e. ten times that of $5 \mathrm{G}$.

- Area traffic capacity of up to $1 \mathrm{~Gb} / \mathrm{s} / \mathrm{m}^{2}$ for scenarios such as hotspots.

- An energy efficiency of 10-100 times and a spectrum efficiency of 5-10 times those of 5G.

Several works [137][138][139][140][141][142][143][136] have already predicted which will be the services supported by next-generation systems that cannot be fully integrated in 5G. Most of the foreseen usage scenarios will evolve from the emerging $5 \mathrm{G}$ use cases, which will add further performance enhancements and new applications. Based on the previous works, we classify them into the following categories:

- Further enhanced Mobile BroadBand (FeMBB): the successor of eMBB in $5 \mathrm{G}$, for ubiquitous conventional mobile communications but with much higher requirements. It should be capable of big data transmission and processing, in addition to new functionalities such as accurate indoor positioning and global compatible connections among different mobile network operators.

- Extremely Reliable and Low-Latency Communications (ERLLC): enhancement of URLLC in $5 \mathrm{G}$ but with higher requirements, e.g. reliability of $99.9999999 \%$, i.e. 'seven sigma', and a latency lower than $0.1 \mathrm{~ms}$. ERLLC would allow industrial and military communications, e.g. robots, high precision machine tools and conveyor systems, as well as autonomous vehicular communications.

- Ultra-massive Machine-Type Communications (umMTC): improvement of mMTC with up to 10 times higher connectivity density, extending the Internet of Things concept to new paradigms such as the Internet of Nano-Things, the Internet of Bodies or nanonetworks, and expanding others such as smart cities and e-health.

- Long-Distance Communications (LDC): for moving or fixed base stations, achieving long-distance transmissions in futuristic scenarios such as hyper-high-speed railway or intersatellite communications in free space. Additionally, this use case is also intended to provide good services not only to dense areas but to remote areas. In such scenarios, the network coverage should be large enough so as to provide an acceptable service independently on where the subscribers are living or moving to.

- Extremely Low-Power Communications (ELPC): novel IoT scenarios such as nanodevices, nanorobots, nanosensors, or Internet of Bio-Nano-Things will require the design of new air-interfaces for ultra-low-power communications, even allowing nanodevices to operate without batteries thanks to energy harvesting technologies.

- Three-Dimensional Integrated Communications (3DIC): extension of the current 2D approach for network analysis, planning and optimization. By considering the height (3D), novel communication types can be implemented such as satellite, UAV (Unmanned Aerial Vehicle), and underwater communications. New features such as beamforming with full-dimensional MIMO architectures may enable these scenarios.

- Unconventional Data Communications (UCDC): this category is intended to cover those novel communication paradigms that cannot be classified into the previous ones. It may cover holographic, tactile, and human bond communications.

The support of these scenarios will allow the development of novel services. Some of these foreseen applications, which might be somewhat futuristic, are summarized next.

- Extremely High-Definition (EHD) video: thanks to the popularity of over-the-top (OTT) services such as Netflix and YouTube, the demand for video content is increasing exponentially. EHD videos with $16 \mathrm{~K}$ and $32 \mathrm{~K}$ formats will become a reality at the same time that the screens of mobile devices and TVs will increase their resolutions. Thus, future wireless networks will have to provide higher bandwidths and lower latencies to cope with these new demands.

- Tactile Internet: this concept, introduced by ITU-T in 2014, enables real-time interactions for services which may vary from medical, education, industrial or entertainment segments. Extremely low-latency, ultra-reliable and secure communications are required.

- Holographic telepresence applications: near-real personal communication or immersive live models with multiple digital avatars from different places are becoming a reality, requiring bandwidths up to terabits per second.

- Haptic communications: this type of communications adds the sense of "touch" to traditional audio-visual communications and will be key for Virtual and Augmented Reality (VAR). Haptic communications may be used for different sectors such as manufacturing, education, healthcare, smart utilities, gaming, etc. Some of these ultra-sensitive applications will require latencies lower than $1 \mathrm{~ms}$ and massive real-time data transfers over the air. This will enable the Internet of Skills (IoS), a new paradigm which allows to "store" the skills of 
different persons which can be shared with anyone who wants to learn something, e.g. painting, playing a musical instrument, or sports. With the help of tactile globes and other wearable devices, the person can use the stored "skill" as a movement reference.

- Automation and manufacturing: many potential application scenarios are expected for the industry, such as extended reality (XR), massive incorporation of robots into automation, warehouse transportation, etcetera. Lowlatency connectivity and accurate indoor positioning are examples of the requirements needed in this area.

- Smart healthcare: a number of solutions for ubiquitous health monitoring have been developed to monitor indicators such as temperature, heart rate, glucose levels, etc. As this information is very sensitive, a high level of security, reliability and availability must be ensured. Other applications such as secure high-definition video conferencing will also be required in order to ensure a seamless experience for remote diagnosis by doctors.

- The Internet of Nano-Things and Bodies: using smart wearable devices, integrated headsets, implantable sensors, etc., this concept will require ultra low-power consumption to support applications from different segments e.g. from military to healthcare.

- Massive IoT integrated smart city: current smart cities can only be fragmentally smart, i.e. considering only some aspects of utilities, healthcare, transportation but separately. Future smart cities are expected to take an integrated approach, which will support massive amounts of data and will require a high level of security.

- Fully autonomous vehicles: the automotive and transportation industries are experiencing a generation change, with standards for vehicle-to-everything (V2X) communications. Nevertheless, the movement of people and goods remains a critical challenge. Autonomous vehicles will require ultra-high reliability, in addition to low latencies and high bandwidth.

- High-quality communication services on board: emerging scenarios such as hyper-high-speed railways or aircrafts will require consistent service experiences, similar to those of conventional mobile environments.

- Underwater and space communications: it is expected that next-generation communication technologies will significantly expand the boundaries of human activity to environments such as deep-sea or outer space.

- Flying networks: providing ubiquitous connectivity to e.g. Unmanned Aerial Vehicles (UAVs) may be challenging for the upcoming wireless networks. In addition to low-latency and high bandwidth requirements, threedimensional analysis, planning and optimization shall be performed to ensure reliability and availability. Considering the node height will be required to implement elevation beamforming with full-dimensional MIMO architectures, which may be required for the proper network functioning.

As commented, the definition of these use cases, their requirements, specific environments and traffic mixes shall be further investigated and incorporated for the design and performance analysis of future mobile systems.

\section{CONCLUSIONS}

In this survey, we have presented an overview of the most significant $5 \mathrm{G}$ usage scenarios and traffic generation models. These environments and traffic models will allow 5G stakeholders and researchers to evaluate the performance of $5 \mathrm{G}$ solutions under the most exigent requirements.

Thanks to the initiatives from many organizations, including standardization development organizations, regional projects, and industry alliances, there is a large number of performance evaluation guidelines for different $5 \mathrm{G}$ innovations intended for particular use cases. We have summarized the contributions from the main SDOs (ITU, 3GPP, IEEE, WiMAX Forum, and TIA) and from the main regional projects and industry alliances (5G PPP -including METIS-II, FANTASTIC-5G, mmMAGIC, SPEED-5G, and 5G-NORMA-, and NGMN). We believe that the work from 3GPP, METIS-II and NGMN should be taken as main references.

Finally, we have discussed which general test cases and traffic models should be considered for the performance evaluation of $5 \mathrm{G}$ solutions. In this regard, we propose to utilize the five usage scenarios from IMT-2020 recommendations, using traffic patterns from the METIS project but updated with some traffic models from the literature.

As a result, the review presented in this paper provides the guidelines to ease the research (validation and testing) as well as future dimensioning of $5 \mathrm{G}$ mobile communications systems and technologies.

\section{REFERENCES}

[1] "ITU-D technologies infrastructures and applications: mobile communications." [Online]. Available: http://www.itu.int/ITU-D/tech/ MobileCommunications/IMT_INTRODUCING/IMT_2G3G4G.html

[2] "Requirements related to technical performance for IMT-Advanced radio interface(s)," ITU-R, Report ITU-R M.2134, 2008. [Online]. Available: http://www.itu.int/dms_pub/itu-r/opb/rep/R-REP-M.21342008-PDF-E.pdf

[3] "IMT vision - Framework and overall objectives of the future development of IMT for 2020 and beyond," ITU-R, Recommendation ITU-R M.2083, 2015. [Online]. Available: http://www.itu.int/rec/RREC-M.2083-0-201509-I

[4] "Guidelines for evaluation of radio interface technologies for IMT2020,” ITU-R, Recommendation ITU-R M.2412, Oct. 2017. [Online]. Available: https://www.itu.int/dms_pub/itu-r/opb/rep/R-REP-M.24122017-PDF-E.pdf

[5] L. Chiaraviglio, N. Blefari-Melazzi, W. Liu, J. A. Gutierrez, J. van de Beek, R. Birke, L. Chen, F. Idzikowski, D. Kilper, P. Monti, A. Bagula, and J. Wu, "Bringing 5G into rural and low-income areas: Is it feasible?" IEEE Communications Standards Magazine, vol. 1, no. 3, pp. 50-57, SEPTEMBER 2017.

[6] P. Ameigeiras, Y. Wang, J. Navarro-Ortiz, P. E. Mogensen, and J. M. Lopez-Soler, "Traffic models impact on OFDMA scheduling design," EURASIP Journal on Wireless Communications and Networking, vol. 2012, no. 1, p. 61, Feb 2012. [Online]. Available: https://doi.org/10.1186/1687-1499-2012-61

[7] L. Chiaraviglio, A. S. Cacciapuoti, G. D. Martino, M. Fiore, M. Montesano, D. Trucchi, and N. B. Melazzi, "Planning 5g Networks Under EMF Constraints: State of the Art and Vision," IEEE Access, vol. 6, pp. 51021-51 037, 2018.

[8] S. Fu, H. Wen, J. Wu, and B. Wu, "Energy-efficient precoded coordinated multi-point transmission with pricing power game mechanism,' IEEE Systems Journal, vol. 11, no. 2, pp. 578-587, June 2017. 
[9] F. Han, S. Zhao, L. Zhang, and J. Wu, "Survey of strategies for switching off base stations in heterogeneous networks for greener 5G systems," IEEE Access, vol. 4, pp. 4959-4973, 2016.

[10] "3GPP - 5G service requirements," Feb. 2017. [Online]. Available: http://www.3gpp.org/news-events/3gpp-news/1831-sa1_5g

[11] "5G vision," Samsung Electronics, White paper, Aug. 2015. [Online]. Available: http://images.samsung.com/is/content/samsung/p5/global/ business/networks/insights/white-paper/5g-vision/global-networksinsight-samsung-5g-vision-2.pdf

[12] "5G use cases and requirements," Nokia, White paper, 2016

[13] H. Tullberg, P. Popovski, Z. Li, M. A. Uusitalo, A. Hoglund, O. Bulakci, M. Fallgren, and J. F. Monserrat, "The METIS 5G system concept: meeting the 5G requirements," IEEE Communications Magazine, vol. 54, no. 12, pp. 132-139, Dec. 2016

[14] E. Dahlman, G. Mildh, S. Parkvall, J. Peisa, J. Sachs, Y. Selén, and J. Sköld, "5G wireless access: requirements and realization," IEEE Communications Magazine, vol. 52, no. 12, pp. 42-47, Dec. 2014.

[15] S. Chen and J. Zhao, "The requirements, challenges, and technologies for $5 \mathrm{G}$ of terrestrial mobile telecommunication," IEEE Communications Magazine, vol. 52, no. 5, pp. 36-43, May 2014.

[16] A. Gupta and R. K. Jha, "A survey of 5G network: architecture and emerging technologies," IEEE Access, vol. 3, pp. 1206-1232, 2015.

[17] L. Gavrilovska, V. Rakovic, and V. Atanasovski, "Visions towards 5G: technical requirements and potential enablers," Wireless Personal Communications, vol. 87, no. 3, pp. 731-757, Apr. 2016.

[18] G. Liu and D. Jiang, "5G: vision and requirements for mobile communication system towards year 2020," Chinese Journal of Engineering, vol. 2016, p. 8, 2016.

[19] P. Marsch, I. D. Silva, O. Bulakci, M. Tesanovic, S. E. E. Ayoubi, T. Rosowski, A. Kaloxylos, and M. Boldi, "5G radio access network architecture: design guidelines and key considerations," IEEE Cоттиnications Magazine, vol. 54, no. 11, pp. 24-32, Nov. 2016.

[20] M. Shafi, A. F. Molisch, P. J. Smith, T. Haustein, P. Zhu, P. D. Silva, F. Tufvesson, A. Benjebbour, and G. Wunder, "5G: a tutorial overview of standards, trials, challenges, deployment, and practice," IEEE Journal on Selected Areas in Communications, vol. 35, no. 6 , pp. 1201-1221, Jun. 2017.

[21] "Minimum requirements related to technical performance for IMT2020 radio interface(s)," ITU-R, Recommendation ITU-R M.2410, Nov. 2017. [Online]. Available: https://www.itu.int/dms_pub/itur/opb/rep/R-REP-M.2410-2017-PDF-E.pdf

[22] "IMT traffic estimates for the years 2020 to 2030," ITU-R, Report ITU-R M.2370-0, Jul. 2015. [Online]. Available: http: //www.itu.int/dms_pub/itu-r/opb/rep/R-REP-M.2370-2015-PDF-E.pdf

[23] C. K. Jao, C. Y. Wang, T. Y. Yeh, C. C. Tsai, L. C. Lo, J. H. Chen, W. C. Pao, and W. H. Sheen, "WiSE: a system-level simulator for 5G mobile networks," IEEE Wireless Communications, vol. 25, no. 2, pp. 4-7, Apr. 2018.

[24] Y. Wang, J. Xu, and L. Jiang, "Challenges of system-level simulations and performance evaluation for 5G wireless networks," IEEE Access, vol. 2, pp. 1553-1561, 2014.

[25] J. An, K. Yang, J. Wu, N. Ye, S. Guo, and Z. Liao, "Achieving sustainable ultra-dense heterogeneous networks for 5G," IEEE Communications Magazine, vol. 55, no. 12, pp. 84-90, Dec 2017.

[26] X. Meng, J. Li, D. Zhou, and D. Yang, "5G technology requirements and related test environments for evaluation," China Communications, vol. 13, no. Supplement2, pp. 42-51, 2016.

[27] "5GCHAMPION." [Online]. Available: http://www.5g-champion.eu/

[28] T. Choi, T. Kim, W. Tavernier, A. Korvala, and J. Pajunpää, "Agile management and interoperability testing of SDN/NFV-enriched 5G core networks," ETRI Journal, vol. 40, no. 1, pp. 72-88, Feb. 2018. [Online]. Available: https://onlinelibrary.wiley.com/doi/abs/10. 4218/etrij.2017-0236

[29] E. C. Strinati, M. Mueck, A. Clemente, J. Kim, G. Noh, H. Chung, I. Kim, T. Choi, Y. Kim, H. K. Chung, G. Destino, A. Pärssinen, N. Chuberre, B. Vautherin, T. Deleu, M. Gineste, and A. Korvala, "5GCHAMPION - disruptive 5G technologies for roll-out in 2018," ETRI Journal, vol. 40, no. 1, pp. 10-25, Feb. 2018. [Online]. Available: https://onlinelibrary.wiley.com/doi/abs/10.4218/etrij.2017-0237

[30] “About ITU." [Online]. Available: http://www.itu.int:80/en/about/ Pages/default.aspx

[31] "Welcome to ITU-R." [Online]. Available: http://www.itu.int/en/ITU$\mathrm{R} /$ information/Pages/default.aspx

[32] "Guidelines for evaluation of radio interface technologies for IMTAdvanced," ITU-R, Report ITU-R M.2135, Dec. 2009. [Online]. Available: https://www.itu.int/dms_pub/itu-r/opb/rep/R-REP-M.21351-2009-PDF-E.pdf
[33] G. Li, J. Wu, Z. Chen, X. Luo, T. Tang, and Z. Xu, "Performance analysis and evaluation for active antenna arrays under three-dimensional wireless channel model," IEEE Access, vol. 6, pp. 19 131-19 139, 2018.

[34] "Long Term Evolution (LTE): Overview of LTE air-interface. technical white paper 2007.” Tech. Rep., 2007. [Online]. Available: http://www.motorola.com

[35] N. Wei, A. Pokhariyal, T. B. Sørensen, T. E. Kolding, and P. E. Mogensen, "Performance of spatial division multiplexing MIMO with frequency domain packet scheduling: From theory to practice," IEEE Journal on Selected Areas in Communications, vol. 26, no. 6, pp. 890900, August 2008

[36] Y. Gao, L. Chen, X. Zhang, and Y. Jiang, "Performance evaluation of Mobile WiMAX with dynamic overhead," in 2008 IEEE 68th Vehicular Technology Conference, Sep. 2008, pp. 1-5.

[37] E. B. Rodrigues, F. Casadevall, P. Sroka, M. Moretti, and G. Dainelli, "Resource allocation and packet scheduling in OFDMA-based cellular networks," in 2009 4th International Conference on Cognitive Radio Oriented Wireless Networks and Communications, June 2009, pp. 1-6.

[38] J. Gross and M. Bohge, "Dynamic mechanisms in OFDM wireless systems: A survey on mathematical and system engineering contributions," TKN Technical Report, 012006.

[39] T. Nguyen and Y. Han, "A proportional fairness algorithm with QoS provision in downlink OFDMA systems," IEEE Communications Letters, vol. 10, no. 11, pp. 760-762, November 2006.

[40] Guocong Song and $\mathrm{Ye} \mathrm{Li,} \mathrm{"Cross-layer} \mathrm{optimization} \mathrm{for} \mathrm{OFDM} \mathrm{wire-}$ less networks-part i: theoretical framework," IEEE Transactions on Wireless Communications, vol. 4, no. 2, pp. 614-624, March 2005.

[41] G. Song and Y. Li, "Cross-layer optimization for OFDM wireless networks-part ii: algorithm development," IEEE Transactions on Wireless Communications, vol. 4, no. 2, pp. 625-634, March 2005.

[42] H. Holma, A. Toskala, K. Ranta-aho, and J. Pirskanen, "High-speed packet access evolution in 3gpp release 7 [topics in radio communications]," IEEE Communications Magazine, vol. 45, no. 12, pp. 29-35, December 2007.

[43] M. Fong, R. Novak, S. Mcbeath, and R. Srinivasan, "Improved voip capacity in mobile wimax systems using persistent resource allocation," IEEE Communications Magazine, vol. 46, no. 10, pp. 50-57, October 2008

[44] M. Rinne and O. Tirkkonen, "Lte, the radio technology path towards 4g," Computer Communications, vol. 33, no. 16, pp. 1894 1906, 2010. [Online]. Available: http://www.sciencedirect.com/science/ article/pii/S0140366410003099

[45] L. A. Vasquez-Toledo and D. Lara-Rodríguez, "Teletraffic analysis of ofdma cellular systems with persistent voip users and maximum sir scheduling based on order statistics," IEEE Access, vol. 6, pp. 25517 25 531, 2018.

[46] Y. C. Sung, Y. Ho, Y. Lin, J. Chen, and H. C. Rao, "Voice/video quality measurement for lte services," IEEE Wireless Communications, vol. 25 , no. 4, pp. 96-103, AUGUST 2018.

[47] "3GPP, the 3rd Generation Partnership Project." [Online]. Available: http://www.3gpp.org/

[48] “3GPP Release 15.” [Online]. Available: http://www.3gpp.org/release15

[49] “3GPP Release 16.” [Online]. Available: http://www.3gpp.org/release16

[50] J. Gozalvez, "Tentative 3GPP timeline for 5G," IEEE Vehicular Technology Magazine, vol. 10, no. 3, pp. 12-18, Sep. 2015.

[51] "3rd Generation Partnership Project; Technical Specification Group Radio Access Network; Study on Scenarios and Requirements for Next Generation Access Technologies," 3GPP, Technical Report 3GPP TR 38.913 V14.3.0, Jun. 2017. [Online]. Available: www.3gpp.org/ dynareport/38913.htm

[52] "3rd Generation Partnership Project; technical Specification Group Radio Access Network; Study on Self Evaluation towards IMT-2020 Submission (Release 16)," 3GPP, Technical Report 3GPP TR 37.910 V16.0.0, Jun. 2019. [Online]. Available: https://portal.3gpp.org/desktopmodules/Specifications/ SpecificationDetails.aspx? specificationId $=3190$

[53] "3rd Generation Partnership Project; technical Specification Group Radio Access Network; Evolved Universal Terrestrial Radio Access (E-UTRA); Further advancements for E-UTRA physical layer aspects (Release 9)," Tech. Rep. 3GPP TR 36.814 V9.2.0, Mar. 2017. [Online]. Available: https://portal.3gpp.org/desktopmodules/ Specifications/SpecificationDetails.aspx ?specificationId $=2493$

[54] "Annex A4 Self-evaluation results for TR36.814," 3GPP, Tech. Rep. 3GPP TSG RAN1 Meeting \#59 R1-094954. [On- 
line]. Available: http://www.3gpp.org/ftp/tsg_ran/WG1_RL1/TSGR1_ 59/Docs/R1-094954.zip

[55] "LTE physical layer framework for performance verification," Tech. Rep. 3GPP TSG-RAN1\#48 R1-070674, Feb. 2007. [Online]. Available: ftp://ftp.3gpp.org/tsg_ran/WG1_RL1/TSGR1_48/Docs/R1-070674.zip

[56] "3rd Generation Partnership Project; Technical Specification Group Radio Access Network; Study on RAN Improvements for Machine-type Communications (Release 11)," Tech. Rep. 3GPP TR 37.868 V11.0.0, Sep. 2011. [Online]. Available: https://portal.3gpp.org/desktopmodules/ Specifications/SpecificationDetails.aspx ?specificationId $=2630$

[57] "3rd Generation Partnership Project; Technical Specification Group Radio Access Network; Study on provision of low-cost Machine-Type Communications (MTC) User Equipments (UEs) based on LTE (Release 12)," 3GPP, Technical Report 3GPP TR 36.888 V12.0.0, Jun. 2013. [Online]. Available: https://portal.3gpp.org/desktopmodules/ Specifications/SpecificationDetails.aspx? specificationId $=2578$

[58] "Traffic model for M2M services," 3GPP, Technical Report 3GPP TSG-RAN WG2 Meeting \#68-bis R2-100204, Jan. 2010. [Online]. Available: http://www.3gpp.org/ftp/tsg_ran/WG2_RL2/TSGR2_68bis/ docs/R2-100204.zip

[59] "3rd Generation Partnership Project; Technical Specification Group Radio Access Network; Study on LTE Device to Device Proximity Services; Radio Aspects (Release 12)," 3GPP, Technical Report 3GPP TR 36.843 V12.0.1, Mar. 2014. [Online]. Available: http: //www.3gpp.org/dynareport/36843.htm

[60] N. Heuveldop, "Ericsson mobility report," Ericsson, Report, Nov. 2017. [Online]. Available: https://www.ericsson.com/assets/local/mobilityreport/documents/2017/ericsson-mobility-report-november-2017central-and-eastern-europe.pdf

[61] N. R. Brnovic, "Trends in the evolution of voice services: a comprehensive survey," Wireless Personal Communications, vol. 97, no. 2, pp. 3141-3148, Nov. 2017.

[62] R. V. Adams, "Performance evaluation of video, voice and web traffic over heterogeneous access networks," Wireless Personal Communications, vol. 99, no. 3, pp. 1195-1215, Apr. 2018. [Online] Available: https://link.springer.com/article/10.1007/s11277-017-51725

[63] A. Gautam and S. Dharmaraja, "Selection of DRX scheme for voice traffic in LTE-A networks: Markov modeling and performance analysis," Journal of Industrial \& Management Optimization, vol. 13, no. 1547-5816 2017 5 126, 2017. [Online]. Available: http: //aimsciences.org//article/id/56e65c75-1b80-4add-a681-7bbf3eca007b

[64] G. Min, J. Hu, and M. E. Woodward, "Performance modelling and analysis of the TXOP scheme in wireless multimedia networks with heterogeneous stations," IEEE Transactions on Wireless Communications, vol. 10, no. 12, pp. 4130-4139, Dec. 2011.

[65] J. W. So, "Performance analysis of VoIP services in the IEEE 802.16e OFDMA system with inband signaling," IEEE Transactions on Vehicular Technology, vol. 57, no. 3, pp. 1876-1886, May 2008.

[66] M. A. A. Masri, A. B. Sesay, and F. M. Ghannouchi, "Energy/Qualityof-Experience tradeoff of power saving modes for voice over IP services," IEEE Transactions on Wireless Communications, vol. 16, no. 6, pp. 4009-4022, Jun. 2017.

[67] H. H. Choi, O. Song, Y. K. Park, and J. R. Lee, "Performance evaluation of opportunistic vertical handover considering on-off characteristics of VoIP traffic," IEEE Transactions on Vehicular Technology, vol. 59, no. 6, pp. 3115-3121, Jul. 2010.

[68] H. H. Choi, O. Song, and J. R. Lee, "Voice-activity-based vertical handover in 3G-WLAN interworking networks," Electronics Letters, vol. 45, no. 21, pp. 1109-1101, Oct. 2009.

[69] A. D. Shaikh, K. J. Blow, M. A. Eberhard, and S. A. Fowler, "Language independent on-off voice over IP source model with lognormal transitions," IET Communications, vol. 7, no. 14, pp. 1449-1455, Sep. 2013.

[70] V. Amaradasa, J. Schormans, J. Pitts, and C. M. Leung, "Evaluating overflow probability for voice over internet protocol buffer dimensioning," IET Communications, vol. 3, no. 4, pp. 636-643, Apr. 2009.

[71] R. Musabe and H. Larijani, "Cross-layer scheduling and resource allocation for heterogeneous traffic in 3G LTE," Journal of Computer Networks and Communications, vol. 2014, p. 13, 2014

[72] P. T. Brady, "A Model for Generating On-Off Speech Patterns in TwoWay Conversation," Bell System Technical Journal, vol. 48, no. 7, pp. 2445-2472, Sep. 1969.

[73] "3rd Generation Partnership Project; Technical Specification Group Services and System Aspects; Performance characterization of the Adaptive Multi-Rate Wideband (AMR-WB) speech codec (Release 14)," 3GPP, Technical Report 3GPP TR 26.976 V14.0.0, Mar.
2017. [Online]. Available: https://portal.3gpp.org/desktopmodules/ Specifications/SpecificationDetails.aspx ?specificationId=1509

[74] "Telephony transmission quality objective measuring apparatus Artificical conversational speech," ITU-T, ITU-T Recommendation ITU-T P.59, Mar. 1993. [Online]. Available: https://www.itu.int/rec/TREC-P.59-199303-I/en

[75] "3rd Generation Partnership Project; technical Specification Group Radio Access Network; Evolved Universal Terrestrial Radio Access (E-UTRA); Study on Voice and Video enhancement for LTE (Release 14)," 3GPP, Technical Report 3GPP TR 36.750 V14.1.0, Mar. 2017. [Online]. Available: https://portal.3gpp.org/desktopmodules/ Specifications/SpecificationDetails.aspx ?specificationId $=3067$

[76] "3rd Generation Partnership Project; technical Specification Group Services and System Aspects; Speech codec speech processing functions; Adaptive Multi-Rate - Wideband (AMRWB) speech codec; General description (Release 14)," 3GPP, Technical Specification 3GPP TS 26.171 V14.0.0, Mar. 2017. [Online]. Available: https://portal.3gpp.org/desktopmodules/ Specifications/SpecificationDetails.aspx?specificationId $=1420$

[77] "3rd Generation Partnership Project; technical Specification Group Services and System Aspects; Codec for Enhanced Voice Services (EVS); General Overview (Release 14)," 3GPP, Technical Specification 3GPP TS 26.441 V14.0.0, Mar. 2017. [Online]. Available: https://portal.3gpp.org/desktopmodules/ Specifications/SpecificationDetails.aspx ?specificationId=1463

[78] "3rd Generation Partnership Project; Technical Specification Group Services and System Aspects; Codec for Enhanced Voice Services (EVS); Performance Characterization (Release 14)," 3GPP, Technical Report 3GPP TR 26.952 V14.0.0, Mar 2017. [Online]. Available: https://portal.3gpp.org/desktopmodules/ Specifications/SpecificationDetails.aspx?specificationId $=1504$

[79] L. Cao, Y. Zhao, Q. Wang, G. Du, S. Xiong, T. Luo, and F. Chen, "VoLTE coverage improvement by HARQ and RLC segmentation when TTI bundling is on," in 2016 IEEE Information Technology, Networking, Electronic and Automation Control Conference, May 2016, pp. 371-375.

[80] P. K. Wali and D. Das, "Enhanced-power saving semi-persistent scheduler for VoLTE in LTE-Advanced," IEEE Transactions on Wireless Communications, vol. 15, no. 11, pp. 7858-7871, Nov. 2016.

[81] A. Sniady, M. Sonderskov, and J. Soler, "VoLTE performance in railway scenarios: investigating VoLTE as a viable replacement for GSM-R," IEEE Vehicular Technology Magazine, vol. 10, no. 3, pp. 60-70, Sep. 2015.

[82] A. Vizzarri, "Analysis of VoLTE End-to-End Quality of Service using OPNET," in 2014 European Modelling Symposium, Oct. 2014, pp. 452457.

[83] O. Ozturk and M. Vajapeyam, "Performance of VoLTE and data traffic in LTE heterogeneous networks," in 2013 IEEE Global Communications Conference (GLOBECOM), Dec. 2013, pp. 1595-1601.

[84] "History of IEEE." [Online]. Available: https://www.ieee.org/about/ ieee_history.html

[85] "About - IEEE 5G." [Online]. Available: https://5g.ieee.org/about

[86] "IEEE 5G and Beyond - Technology roadmap white paper," IEEE, White paper, Oct. 2017. [Online]. Available: https://5g.ieee.org/images/ files/pdf/ieee-5g-roadmap-white-paper.pdf

[87] D. Stanley, "IEEE 802.11 radio components in 5G wireless," Hewlett Packard, Tech. Rep., May 2017. [Online]. Available: https://www.industryhk.org/upload/media/file/ bdedb9599302541da2d4972ea80ac964.pdf

[88] "IEEE 802.16m evaluation methodology document (EMD)," Tech. Rep. IEEE $802.16 \mathrm{~m}-08 / 004 \mathrm{r} 2$, Jul. 2008. [Online]. Available: http://ieee802.org/16/tgm/docs/80216m-08_004r2.pdf

[89] R. Irmer, "NGMN radio access performance evaluation methodology v1.0," Tech. Rep., Jan. 2008. [Online]. Available: https://www.ngmn.org/fileadmin/user_upload/NGMN Radio_Access_Performance_Evaluation_Methodology.pdf

[90] F. Fitzek and M. Reisslein, "MPEG-4 and H.263 video traces for network performance evaluation," Network, IEEE, vol. 15, no. 6, pp. 40-54, Nov. 2001

[91] "Machine to Machine (M2M) ccommunications technical report," IEEE 802.16's Machine-to-Machine (M2M) Task Group, Technical Report IEEE 802.16p-10/0005, Nov. 2010. [Online]. Available: http://ieee802.org/16/m2m/docs/80216p-10_0005.doc

[92] H. Li, B. Hamzeh, Y.-S. Choi, S. Mohanty, and C.-Y. Hsu, "Proposal for evaluation methodology for 802.16p," IEEE 802.16's Machineto-Machine (M2M) Task Group, Official Document IEEE C802.16p- 
11/0102r2, May 2011. [Online]. Available: http://wirelessman.org/ $\mathrm{m} 2 \mathrm{~m} /$ contrib/C80216p-11_0102r2.doc

[93] W. Forum, "About the WiMAX Forum." [Online]. Available: http://www.wimaxforum.org/Page/About

[94] "WiMAX system evaluation methodology v2.1," WiMAX Forum, Tech. Rep., Jul. 2008. [Online]. Available: http://www.cse.wustl.edu/ jain/wimax/ftp/wimax_system_evaluation_methodology_v2_1.pdf

[95] "About I Telecommunications Industry Association." [Online]. Available: https://sites.tiaonline.org/about/

[96] "Final report on the evaluation of candidate Radio Interface Technologies for the terrestrial component of IMT-Advanced," Telecommunications Industry Association (TIA), Technical Report TR45-AHIMT, May 2012. [Online]. Available: http://ftp.tiaonline.org/TR45/TR-45_AHIMT/Public/TR-45_Final_Report.pdf

[97] “5G-PPP.” [Online]. Available: https://5g-ppp.eu/

[98] M. Maternia and S. E. El Ayoubi, "5G-PPP use cases and performance evaluation modeling v1.0," 5G PPP, White paper, Apr. 2016. [Online]. Available: https://5g-ppp.eu/wp-content/uploads/2014/02/5G-PPP-usecases-and-performance-evaluation-modeling_v1.0.pdf

[99] "METIS-II, Mobile and wireless communications Enablers for Twenty-twenty (2020) Information Society II.” [Online]. Available: https://metis-ii.5g-ppp.eu/

[100] "FANTASTIC-5G, Flexible Air iNTerfAce for Scalable service delivery within wIreless Communication networks of the 5th Generation." [Online]. Available: http://fantastic5g.com/

[101] "mmMAGIC, mm-wave based Mobile radio Access network for 5G I."

[102] "SPEED-5G, Quality of Service provision and capacity expansion through Extended-DSA for 5G." [Online]. Available: https://speed5 g.eu/

[103] "The METIS 2020 Project." [Online]. Available: https://www. metis2020.com/

[104] J. F. Monserrat, G. Mange, V. Braun, H. Tullberg, G. Zimmermann, and O. Bulakci, "METIS research advances towards the $5 \mathrm{G}$ mobile and wireless system definition," EURASIP Journal on Wireless Communications and Networking, vol. 2015, no. 1, p. 53, Dec. 2015.

[105] J. F. Monserrat and M. Fallgren, "Simulation guidelines," METIS Deliverable D6.1, Oct. 2013. [Online]. Available: https://www. metis2020.com/wp-content/uploads/deliverables/METIS_D6.1_v1.pdf

[106] "3rd Generation Partnership Project; Technical Specification Group Radio Access Network; Study on LTE-based V2x Services (Release 14)," 3GPP, Technical Report 3GPP TR 36.885 V14.0.0, Jun. 2016. [Online]. Available: https://portal.3gpp.org/desktopmodules/ Specifications/SpecificationDetails.aspx ?specificationId $=2934$

[107] M. Fallgren and B. Timus, "Scenarios, requirements and KPIs for 5G mobile and wireless system," Deliverable D1.1, Apr. 2013. [Online]. Available: https://www.metis2020.com/wp-content/uploads/ deliverables/METIS_D1.1_v1.pdf

[108] A. Osseiran, F. Boccardi, V. Braun, K. Kusume, P. Marsch, M. Maternia, O. Queseth, M. Schellmann, H. Schotten, H. Taoka, H. Tullberg, M. A. Uusitalo, B. Timus, and M. Fallgren, "Scenarios for $5 \mathrm{G}$ mobile and wireless communications: the vision of the METIS project," IEEE Communications Magazine, vol. 52, no. 5, pp. 26-35, May 2014.

[109] F. Schaich, B. Sayrac, S. Elayoubi, I.-P. Belikaidis, M. Caretti, A. Georgakopoulos, X. Gong, E. Kosmatos, H. Lin, P. Demestichas, B. Mouhouche, K. Pedersen, N. Pratas, M. Schellmann, M. Schubert, M. Shaat, and G. Wunder, "FANTASTIC-5G: flexible air interface for scalable service delivery within wireless communication networks of the 5th generation," Transactions on Emerging Telecommunications Technologies, vol. 27, no. 9, pp. 1216-1224.

[110] "Air interface framework and specification of system level simulations," FANTASTIC-5G, Deliverable D2.1, May 2016. [Online]. Available: http://fantastic5g.com/wp-content/uploads/2016/ 06/FANTASTIC-5G_D21_public.pdf

[111] "Initial concepts on 5G architecture and integration," mmMAGIC Deliverable H2020-ICT-671650-mmMAGIC /D3.1, Mar. 2016. [Online]. Available: https://bscw.5g-mmmagic.eu/pub/bscw.cgi/94809

[112] M. Tercero, P. v. Wrycza, A. Amah, J. Widmer, M. Fresia, V. Frascolla, J. Lorca, T. Svensson, M. H. Hamon, S. D. Roblot, A. Vijay, M. Peter, V. Sgardoni, M. Hunukumbure, J. Luo, and N. Vucic, "5g systems: the mmMAGIC project perspective on use cases and challenges between 6 \#x2013;100 GHz," in 2016 IEEE Wireless Communications and Networking Conference, Apr. 2016, pp. 1-6.

[113] "SPEED-5G enhanced functional and system architecture, scenarios and performance evaluation metrics," SPEED5G, Deliverable D3.2, Nov. 2016. [Online]. Available: https://speed-5g.eu/wp-content/uploads/2017/01/speed5g-d3.2v1.2_enhanced_functional_and_system_architecture.pdf
[114] O. Carrasco, "Scenarios and models for 5G performance evaluation in SPEED-5G," Kista, Sweden, Sep. 2015. [Online]. Available: https://speed-5g.eu/wp-content/uploads/2015/09/SPEED-5GPresentation-Performance-Eval-METIS-II-Workshop-29Sep2015.pdf

[115] S. Mumtaz, "RM framework and modelling," Speed5G, Deliverable D4.2, Apr. 2017. [Online]. Available: https://speed-5g.eu/wp-content/ uploads/2017/06/speed5g-d4.2_rm-framework-and-modelling.pdf

[116] "5G NORMA, NOvel Radio Multiservice adaptive network Architecture." [Online]. Available: https://5gnorma.5g-ppp.eu/

[117] C. Mannweiler, M. Breitbach, H. Droste, I. L. Pavón, I. Ucar, P. Schneider, M. Doll, and J. R. Sanchez, "5G NORMA: system architecture for programmable multi-tenant 5g mobile networks," in 2017 European Conference on Networks and Communications (EuCNC), Jun. 2017, pp. $1-6$.

[118] S. Purge, "Use cases, scenarios and requirements," Project: H2020ICT-2014-2 5G NORMA, Deliverable D2.1, Oct. 2015. [Online]. Available: http://www.it.uc3m.es/wn1/5gnorma/pdf/5g_norma_d2-1.pdf

[119] "3rd Generation Partnership Project; Technical Specification Group Radio Access Network; Study on elevation beamforming / FullDimension (FD) Multiple Input Multiple Output (MIMO) for LTE," 3GPP, Technical Report 3GPP TR 36.897 v13.0.0, Jun. 2015. [Online]. Available: https://portal.3gpp.org/desktopmodules/ Specifications/SpecificationDetails.aspx? specificationId $=2580$

[120] J. Bradford, "Evaluation architecture design and socioeconomic analysis - final report," Project: H2020-ICT-2014-2 5G NORMA, Deliverable D2.3, Dec. 2017. [Online]. Available: http://www.it.uc3m. es/wn1/5gnorma/pdf/5g_norma_d2-3.pdf

[121] A. Annunziato, "5G vision: NGMN - 5G initiative," in 2015 IEEE 81st Vehicular Technology Conference (VTC Spring), May 2015, pp. 1-5.

[122] M. Iwamura, "NGMN view on 5G architecture," in 2015 IEEE 81st Vehicular Technology Conference (VTC Spring), May 2015, pp. 1-5.

[123] R. El Hattachi and J. Erfanian, "NGMN 5G white paper v1.0," Tech. Rep., Feb. 2015. [Online]. Available: https://www.ngmn.org/fileadmin/ngmn/content/downloads/ Technical/2015/NGMN_5G_White_Paper_V1_0.pdf

[124] Y. Lee and M. Caretti, "Test and Technology Building Block (TTBB)," NGMN Alliance, Deliverable, Jun. 2017. [Online]. Available: https://www.ngmn.org/fileadmin/ngmn/content/downloads/ Technical/2017/170629_TTBB_report_v1.0.pdf

[125] H. Elshaer, "Definition of the testing framework for the NGMN 5G pre-commercial network trials," NGMN Alliance, Deliverable, Jan. 2018. [Online]. Available: https: //www.ngmn.org/fileadmin/ngmn/content/downloads/Technical/2018/ 180220_NGMN_PreCommTrials_Framework_definition_v1_0.pdf

[126] "NGMN liaison statement to 5GAA," NGMN Alliance, Tech. Rep., Oct. 2017. [Online]. Available: https://www.ngmn.org/fileadmin/user_ upload/171011_NGMN_LS_on_Technology_Evaluation_of_LTEV2X_and_DSRC_to_5GAA_Simulation_Assumptions.pdf

[127] P. Ameigeiras, Y. Wang, J. Navarro-Ortiz, P. E. Mogensen, and J. M. Lopez-Soler, "Traffic models impact on OFDMA scheduling design," EURASIP Journal on Wireless Communications and Networking, vol. 2012, p. 61, Feb. 2012. [Online]. Available: https://doi.org/10.1186/1687-1499-2012-61

[128] S. Ihm and V. S. Pai, "Towards understanding modern web traffic," in Proceedings of the 2011 ACM SIGCOMM Conference on Internet Measurement Conference, ser. IMC '11. New York, NY, USA: ACM, 2011, pp. 295-312.

[129] R. Pries, Z. Magyari, and P. Tran-Gia, "An HTTP web traffic model based on the top one million visited web pages," in 2012 8th EURONGI Conference on Next Generation Internet (NGI), Jun. 2012, pp. 133-139.

[130] I. Tsompanidis, A. H. Zahran, and C. J. Sreenan, "Mobile network traffic: A user behaviour model," in Wireless and Mobile Networking Conference (WMNC), 2014 7th IFIP, May 2014, pp. 1-8.

[131] C. Fang, J. Liu, and Z. Lei, "Fine-grained HTTP web traffic analysis based on large-scale mobile datasets," IEEE Access, vol. 4, pp. 43644373, 2016.

[132] G. Zhao, M. Yu, C. Xu, and H. Tang, "Generating web traffic based on user behavioral model," Journal of Communication and Computer, vol. 11, pp. 59-65, 2014.

[133] "Recommended upload encoding settings - YouTube Help." [Online]. Available: https://support.google.com/youtube/answer/1722171?hl=en

[134] Skype, "How much bandwidth do I need for calls?" [Online]. Available: https://support.skype.com/en/faq/fa1417/howmuch-bandwidth-does-skype-need 
[135] K. Žvinys, "Voice calls users' behavior in terms of call duration," in 2016 Open Conference of Electrical, Electronic and Information Sciences (eStream), Apr. 2016, pp. 1-4.

[136] F. Tariq, M. Khandaker, K. K. Wong, M. Imran, M. Bennis, and M. Debbah, "A speculative study on 6G," arXiv:1902.06700, 2019.

[137] Z. Zhang, Y. Xiao, Z. Ma, M. Xiao, Z. Ding, X. Lei, G. K. Karagiannidis, and P. Fan, "6G wireless networks: Vision, requirements, architecture, and key technologies," IEEE Vehicular Technology Magazine, vol. 14 , no. 3, pp. 28-41, Sep. 2019.

[138] E. Calvanese Strinati, S. Barbarossa, J. L. Gonzalez-Jimenez, D. Ktenas, N. Cassiau, L. Maret, and C. Dehos, "6G: The next frontier: From holographic messaging to artificial intelligence using subterahertz and visible light communication," IEEE Vehicular Technology Magazine, vol. 14, no. 3, pp. 42-50, Sep. 2019.

[139] K. David and H. Berndt, "6G vision and requirements: Is there any need for beyond 5G?" IEEE Vehicular Technology Magazine, vol. 13, no. 3, pp. 72-80, Sep. 2018.

[140] S. Dang, O. Amin, B. Shihada, and M.-S. Alouini, "From a humancentric perspective: What might 6G be?" arXiv:1906.00741, 2019.

[141] A. Yastrebova, R. Kirichek, Y. Koucheryavy, A. Borodin, and A. Koucheryavy, "Future networks 2030: Architecture and requirements," in 2018 10th International Congress on Ultra Modern Telecommunications and Control Systems and Workshops (ICUMT), Nov 2018, pp. $1-8$.

[142] M. Latva-aho and K. Leppänen, Key drivers and research challenges for $6 G$ ubiquitous wireless intelligence (white paper). University of Oulu, Sep 2019.

[143] B. Zong, C. Fan, X. Wang, X. Duan, B. Wang, and J. Wang, "6G technologies: Key drivers, core requirements, system architectures, and enabling technologies," IEEE Vehicular Technology Magazine, vol. 14, no. 3, pp. 18-27, Sep. 2019. 